\title{
Failure of Man-Made Cavities in Salt and Surface Subsidence Due to Sulfur Mining
}

Glenda K. Coates, Cheryl A. Lee, William C. McClain, Paul E. Senseny

RE/SPEC, Inc., P.O. Box 725

Rapid City, SD 57709

Prepared by Sandia National Laboratories, Albuquerque, New Mexico 87185 and Livermore, California 94550 for the United States Department of Energy under Contract DE-AC04-76DP00789

Printed January 1981

$$
\text { NOTICE }
$$

PORTIONS OF THIS REPORT ARE ILLEGIBLE. It has been revrofinced from the best available copy to permit the broadest possible availability.

Prepared for Sandia National Laboratories under Contract No. 49-5723 


\section{DISCLAIMER}

This report was prepared as an account of work sponsored by an agency of the United States Government. Neither the United States Government nor any agency Thereof, nor any of their employees, makes any warranty, express or implied, or assumes any legal liability or responsibility for the accuracy, completeness, or usefulness of any information, apparatus, product, or process disclosed, or represents that its use would not infringe privately owned rights. Reference herein to any specific commercial product, process, or service by trade name, trademark, manufacturer, or otherwise does not necessarily constitute or imply its endorsement, recommendation, or favoring by the United States Government or any agency thereof. The views and opinions of authors expressed herein do not necessarily state or reflect those of the United States Government or any agency thereof. 


\section{DISCLAIMER}

Portions of this document may be illegible in electronic image products. Images are produced from the best available original document. 
Issued by Sandia National Laboratories, operated for the United States Department of Energy by Sandia Corporation.

NOTICE: This report was prepared as an account of work sponsored by an agency of the United States Government. Neither the United States Government nor any agency thereof, nor any of their employees, nor any of their contractors, subcontractors, or their employees, makes any warranty, expres or implied, or assumes any legal liability or responsibility for the accuracy, completeness, or usefulness of any information, apparatus, product, or process disclosed, or represents that its use would not infringe privately owned rights. Reference herein to any specific commercial product, proces rights. Reference herein to any specific commercial product, process, or service by trade name, trademark, manufacturer, or otherwise, does not necessarily constitute or imply its endorsement, recommendation, or favoring by the United States Government, any agency thereof or any of their contractors or subcontractors. The views and opinions expressed herein do not necessarily state or reflect those of the United States Government, any agency thereof or any of their contractors or subcontractors. 
SAND $-81-7145$

DE82 008628

FAILURE OF MAN-MADE CAVITIES IN SALT AND

SURFACE SUBSIDENCE DUE TO SULFUR MINING.

TOPICAL REPORT RSI-0131

Submitted To

Strategic Petroleum Reserve

Geotechnical Division

Sandia National Laboratories

Albuquerque, NM 87185

By

Glenda K. Coates

Cheryl A. Lee

William C. McClain

Paul E. Senseny

January 30, 1981

This report was prepared by RE/SPEC Inc. under Contract Document No. $4 y-5 / 23$ with the sand 1 a Corporation under Contract AT (29-1)-789 with the United States Department of Energy. The contract with RE/SPEC Inc. was administered by Sandia Laboratories as operated by the Sandia Corporation. 
An engineering data base relevant to subsidence due to sulfur mining and to structural failure of cavities in salt is established, evaluated and documented. Nineteen failure events are discussed. Based on these documented failure events, capabilities of and inputs to a mathematical model of cavity failure are determined. Two failure events are adequately documented for use in model verification studies. A conclusion of this study that is pertinent to the Strategic Petroleum Reserve is that cavity failures in dome salt are fairly rare, but that as the number of large cavities (especially those having large roof spans) increases, failures will probably be more common unless stability and failure mechanisms of cavities are better understood. 


\section{FOREWORD}

This report was prepared under a contract with Sandia National Laboratories, which directs the geotechnical studies for the Department of Energy's Strategic Petroleum Reserve program. The objective of the Strategic Petroleum Reserve program is to stockpile large quantities of petroleum that can be drawn upon in the event of interruption of the flow of foreign oil into the United States.

The geotechnical. studies directed by Sandia comprise five tasks: site characterization, materials testing, engineering evaluation, long-term monitoring and instrumentation. The study described in this report was performed in support of the engineering evaluation task.

The Sandia technical monitor of this project was Dr. J. R. Tillerson. This study complements his effort of documenting the failure of cavern No. 7 at Bayou Choctaw that resulted in cavity loss and surface subsidence.

This report presents the results of a survey of failures of man-made cavities in bedded and dome salt and of surface subsidence due to sulfur mining over salt domes. The objective of this survey is to establish, document and evaluate an engineering data base relevant to cavity failure and surface subsidence that can be used to evaluate models to assess cavity stability and to predict failure and failure sequence and geometry.

The authors are indebted to Ms. Julie S. Annicchiarico, Ms. Rhonda K. Ellis, and Ms. Jean Wilson for carefully typing this report. The somments of Dr. David J. Knight, who reviewed this report, are greatly appreciated. 
ABSTRACT

FOREWORD

LIST OF FIGURES

LIST OF TABLES

viii

EXECUTIVE SUMMARY

1. INTRODUCTION

1.1. Background

1.2. Approach and Scope

1.3. Report Organization

2. MODELING

2.1. Introduction

2.2. Model Capabilities

2.3. Model Inputs 6

2.3.1. Cavity Size and Shape 7

2.3.2. Cavity Location 7

2.3.3. In Situ Stress 7

2.3.4. Stratigraphy 8

2.3.5. Formation and Operating Histories 8

2.3.6. Constitutive Laws 8

2.4. Failures Suitable for Model Validation 8

3. STABILITY PROBLEMS OF MINING AND STORAGE CAVITIES IN SALT DOMES 10

3.1. Eminence Salt Dome, Covington County, Mississippi 10

3.2. Keil 101 Storage Cavern 22

3.3. Belle Isle Salt Mine, St. Mary Parish, Louisiana 30

3.4. - Blue Ridge Salt Dome, Fort Bend County, Texas 33

3.5. Grand Saline Salt Dome, Van Zandt County, Texas 36

3.6. Winnfield Sait Dome 43

4. STABILITY PROBLEMS OF MINING CAVITIES IN BEDDED SALT 49

4.1. Subsidence at Grosse Ile, Michigan 49

4.?. Windson, Canada, 1954 Subsidence 60

4.3. Hutchinson, Kansas, Subsidence, 192571

4.4. Barton Salt Co. Subsidence, Hutcrionson, Kansass. 195275

4.5. Cargili Subsidence, Hutchinson, Kansas, 197482

4.6. Interpace Corporation-Carey Sait Division, 90

Subsidence, Hutchinson, Kansas, 1978
4.7. Cheshire Basin, Cheshire, England 
5. SUBSIDENCE DUE TO SULFUR MINING 99

5.1. Fannett Salt Dome, Jefferson County, Texas 99

5.2. Sulphur Mines Salt Dome, Calcasieu Parish, Louisiana 108

5.3. Hoskins Mound Salt Dome, Brazoria County. Texas 111

5.4. Grande Ecaille, Plaquemines Parish, Louisiana 114

5.5. Spindletop Salt Dome, Jefferson County, Texas 116

5.6. Boling Salt Dome, Wharton County, Texas , 118

6. CONCLUSIONS, 120

CITED REFERENCES 122

BIBLIOGRAPHY . 126 


\section{LIST OF FIGURES}

FIGURE NO.

PAGE

3.1.1. Stratigraphy of Eminence Salt Dome . 12

3.1.2. Eminence Cavern Profile 14

3.1.3. Volume and Pressure as Functions of Time for 15 Eminence Cavern No. 1

3.1.4. Volume and Pressure as Functions of Time for 17 Emínence Cavern No. 2

3.1.5. Volume and Pressure as Functions of Time for 19 Eminence Cavern No. 3

3.1.6. Volume and Pressure as Functions of Time for . $\quad 20$ Eminence Cavern No. 4

3.2.1. Casing and Tubing Geometry When Leaching Began $\because \quad: \quad 24$

3.2.2. Volume Change, Water Removed and Water Level as 27 a Function of Time for the Keil 101 Storage Cavern

3.2.3. Depth of Water Level as a Function of Time for 28 the Keil 101 Storage Cavern

3.2.4. Cross Section of Keil 101 Storage Cavern Indicating Volume Loss Due to Collapse and Closure

3.4.1. Diagrammatic Section of the Blue Ridge Salt Mine 34 Prior to and After the Collapse of 1949

3.5.1. Overview of the Sinkhole that Appeared in Grand . 37 Saline, Texas, on April 27, 1976

3.5.2. City map of Grand Saline, Texas, Showing Approximate Locations of Sinkholes and Area Where Brine and Sewer Water Seeped to the Surface During the 1976 Collapse

3.5.3. Photograph Showing Surface Cracks Around the 1976 Grand Saline Sinkhole 


\section{LIST OF FIGURES (CONT'D)}

FIGURE NO.

PAGE

3.5.4. Photograph Showing Location of the Sewer Line in the 1976 Grand Saline Sinkhole

3.6.1. Topographic View of Winnfield Salt Dome 44

3.6.2. Section of Winnfield Salt Dome, Winn Parish, 45

4.1.1. Location of Sinkholes, Gallerjes, and Brine Wells 50

1.1.2. Typical Corc of Point llennepin Bilite Field 53

4.1.3. Subsidence Profiles along a Section Through Both . 55 Sinkholes at Grosse Ile, Mịchigan

4.1.4. Typical Settlement Versus Time Curve (Well 35A), 58

4.2.1. Typical Section Underlying the Windsor Brine Field 61

4.2.2. Windsor Brine Field and Operations Buildings 64

4.2.3. Profile Through the Westerly Portion of the 70 Subsidence Area at Windsor

4.3.1. Location of Brine Wells and Surface Cracks in 72 Hutchinson, Kansas

4.3.2. Surface Subsidence as a Function of Time at 73 Various Observation Points in Downtown Hutchinson, Kansas, 1925

4.4.1. Máp Showing the Cargill Salt Plant, Subsidence Areas, Sinkhole, Airlift Field, and Brine Wells in the NW/4 of Section 19, Township 23 South, Range 5 West

4.4.2. North Boring Layout for the Barton Sinkhole 78

4.4.3. North Boring Results for the Barton Sinkhole 79

4.5.1. Typical Geologic Section Underlying the Cargill 83

4.5.2. Index Map and Conceptual Sketch of the Cargill 84 Sinkhole, Showing Underground Condition Along a Northeast-Southwest Cross Section 


\section{LIST OF. FIGURES (CONT 'D)}

FIGURE NO.

4.5.3. Map Showing the Cargill Salt Plant, Subsidence Areas, Sinkhole, Airlift Field, and Brine Wells in the NW/4 of 'Section 19, Township 23 South, Range 5 West

4.6.1. Typical Geologic Section Underlying Carey Salt Plant 91

4.6.2. Brine Well and Boring Locations of Carey, Salț. 92

$$
\text { Brine Field }
$$

5.1.1. Fannett Dome Subsidence Contours After 9 Months of Production

5.1.2. Fannett Dome Subsidence Contours After 15 Months of Production

5.1.3. Fannett Dome Subsidence Contours After 21 Months of Production

5.1.4. Fannett Dome Subsidence Contours After 31 Months of Production

5.1.5. Subsidence Profile Along East-West Base Line No. 1105

5.1.6. Fannett Dome Settlement-Versus-Time Curves for Three Points

5.3.1. Contour Map Depicting the Depth to the Caprock on Hosk ins Mound

5.3.2. C - C Cross Section of Hoskins Mound, Texas 


\section{LIST OF. TABLES}

TABLE NO.

PAGE

S.1. Summary of Data Collected for the Failure Events

3

3.1.1 Design Criteria for Eminence Storage Facility 12

4.1.1 Production History of Grosse Ile Brine Field 51

5.2.1 Elevation Changes at Sulphur Mines Between : 109

5.6.1. Sulfur Production at Boling. Dome 118 


\section{EXECUTIVE SUMMARY}

This report describes work. performed to establish, evaluate and document an engineering data base relevant to failure of man-made cavities in salt. This is the first, step in developing proven capability to perform stability and failure analyses of salt cavities. This analysis capability will aid the Strategic Petroleum Reserve to assess the structural stability and the potential for damage to other structures by cavity failure of existing and planned petroleum storage cavities.

A bibliography comprising 150 references germane to cavity failure in salt and surface subsidence due to sulfur mining was compiled. 'Data were collected for nineteen failure and subsidence events and a case history of each event was prepared. Table $S .1$ summarizes the kinds of data collected for each event. Failures are recorded for solution mines as well as dry mine cavities. Failure types include excessive cavity closure resulting in lost storage capacity, cavity collapse resulting in.: surface subsidence, and flooding resulting in cavity loss.

Mechanisms that control and contribute to cavity failure have been identified. Understanding these failure mechanisms is vital to analys is of cavity failure. For example, excessive cavity closure is controlled by the creep of salt when subjected to shear stress. For a given cavity size and shape and cavity pressure, the shear stress, is proportional to the in situ stress, so the greater the in situ stress, the greater the shear sitress and cavity closure rate. The in situ stress is usually greater at depth, so excessive cavity closure is more likkely to be the failure mechanism.for deep cavities rather than for shallow cavities.

Creep of salt, also contributes th ravity collapse and surface subsidence. In these failures, salt in the roof and walls of the cavity creeps and transfers load to the more brittle overlying strata.: The increased load in these layers causes them to sag into. the cavity and often results in a gradually increasing trough subsidence. Then, as the stress and deformation in these layers increase, a second mechanism, either simultaneous failure of the brittle material on a conical surface (plugging) or progressive failure of the brittle layers (stoping); contributes to the cavity failure. Plugging results in immediate sinkhole formation as the plug drops into the cavity. During stoping, blocks and fragments of failed material fall into the cavity, and the cavity migrates 
towards the surface. If the volume of the cavity is small or the cavity is deep, the blocks of failed material will fill the cavity and support the roof, stopping the migration. This may produce a sinkhole, but more likely the result is simply increased general subsidence or formation of a trough. If, however, the cavity is large or shallow, the blocks of failed material will not fill the cavity and the stoping reaches the surface, producing a sinkhole.

These same failure scenarios can occur if, instead of creep of the salt in the cavity roof leading to progressive failures, the failure is caused by weakening of the brittle layers by penetration of water or brine. As the roof fails and falls away, higher layers are exposed to the brine, deteriorate and fail, exposing even higher layers: neterioration of strength in the presence of water is common to many rocks, especially the argillaceous rocks overlying many salt formations.

Analysis of the data show that for cavities in salt domes, excessive cavity closure is not observed for shallow cavities. Shallow cavities, however, are susceptable to plugging or stoping failure if the roof of the cavity is too near a thin or weak caprock. In bedded salt, cavity collapse and sinkhole formation is usually preceded by trough subsidence. This is generally because the large galleries formed when single-well brine cavities coalesce have large roof spans and high extraction ratios which promote downwarping. These phenomena could be observed in the future in salt domes as the density of cavities increases and cavities coalesce producing large roof spans and high extraction ratios.

Based on the failure data obtained and the failure mechanisms identified, capabilities of and input to a mathematical model to analyze cavity stability and failure are described. Model capabilities include simulating complex three-dimensional geometries, handling nonlinear timedependent and time-independent constitutive laws and nonlinearities resulting from large geometry changes. Model inputs include cavity size and shape, cavity location, in situ stress, stratigraphy, and constitutive laws.

Two failure events are documented adequately to provide the required model inputs and the engineering data related to the failure to be used for model verification. The first is the excessive closure of storage cavities in Eminence Dome. The second is the cavity collapse and surface subsidence over a brine field in bedded salt at Grosse Ile, Michigan. 
S. 1 SUMMARY OF DATA COLLECTED FOR THE FAILURE EVENTS

\begin{tabular}{|c|c|c|c|c|c|c|c|c|}
\hline $\begin{array}{c}\text { Failure of Mining and Storage } \\
\text { Cavities in salt Domes }\end{array}$ & Stratigraphy & $\begin{array}{l}\text { Cavity } \\
\text { Location }\end{array}$ & $\begin{array}{l}\text { Operating } \\
\text { Pressure }\end{array}$ & $\begin{array}{c}\text { Closure } \\
\text { Rate }\end{array}$ & $\begin{array}{l}\text { Solutioned } \\
\text { Cavity Size }\end{array}$ & $\begin{array}{l}\text { Sinkhole } \\
\text { Size }\end{array}$ & $\begin{array}{l}\text { Rate of } \\
\text { Subsidence }\end{array}$ & $\begin{array}{l}\text { Sulfur } \\
\text { Production }\end{array}$ \\
\hline Eminence Salt Dome & $x$ & $x$ & $x$ & $x$ & $x$ & & & \\
\hline Keil 101 Storage Cavern & $x$ & $\frac{x}{x}$ & $x$ & $\frac{x}{x}$ & $\frac{x}{x}$ & & & \\
\hline BTue Ridge Salt Dome & $\bar{x}$ & $x$ & & & & $\bar{x}$ & & \\
\hline Grande Sal ine Salt Dome & $x$ & & & & & $x$ & & \\
\hline Winnfield Salt Dome & $x$ & & & & & & & \\
\hline Grosse Ile, Michigan & $x$ & & & & & $x$ & $x$ & \\
\hline Windsor, Canada & $\bar{x}$ & & & & & $\bar{x}$ & $x$ & \\
\hline Hutchinson, Kansas 1925 & $x$ & & & & & & $x$ & \\
\hline Barton Salt Co., 1952 & $\frac{1}{x}$ & & & & & $\bar{x}$ & & \\
\hline Cargill, 1974 & $\bar{x}$ & & & & & $\bar{x}$ & & \\
\hline Carey Salt, 1978 & $x$ & & & & & $\bar{x}$ & & \\
\hline Sulphur Mines Salt Dome & $\frac{X}{x}$ & & & & & & $\frac{n}{x}$ & $\frac{n}{x}$ \\
\hline Hoskins Mound Salt Dome & $\bar{x}$ & & & & & & & \\
\hline Grande Ecaille & $x$ & & & & & & & $x$ \\
\hline Spindletop Salt Dome & $x$ & & & & & & & $\frac{n}{x}$ \\
\hline Boling Salt Dome & $x$ & & & & & & & $\bar{x}$ \\
\hline
\end{tabular}




\section{INTRODUCTION}

\subsection{Background}

The Strategic Petroleum Reserve (SPR) has the responsibility to store up to one billion barrels of crude oil that can be drawn upon to offset an interruption of the flow of foreign oil into the United States. Storage of large quantities of crude oil in above-ground facilities is impractical because of very high construction and maintenance costs and because of the vulnerability of surface facilities to sabotage or attack. SPR has decided to store the oil in a number of cavities in several salt domes along the U.S. Gulf Coast. Underground cavities, especially in salt, are commonly used for storage in the petroleum and chemical industries, but on a much smaller scale than that required for SPR.

Structural failure of cavities in salt domes is rare; only six such failures in the U.S. are reported. This is probably because current design methodology is conservative; generally, caverns are relatively small and widely spaced. Therefore, stability and failure analysis of SPR cavities would seem to be low priority. However, the number of large cavities needed by the SPR, the value of the crude oil stored in those cavities and the high visibility of the SPR nronram raguire that the r.tahilitiy of existing and planned cavities be assessed and that the potential for damage to other structures by cavity failure be determined.

Proven capability is not available to perform stability and failure analyses of cavities, and therefore, needs to be developed. The first step in developing this capability is to establish, evaluate and document an engineering data base relevant to failure of man-made cavities in salt formations. The second step is to construct a mathematical model for st.ability and failure analyses based in part on these data. The third step is to verify the model by accurately simulating well-documented failure events.

\subsection{Approach and Scope}

This report gives an engineering data base relevant to failure of salt cavities that was constructed by performing a survey of the published literature and by contacting mine owners and operators to obtain unpublished data. Data collected for each failure event are recorded in 
case histories. Some failure events are documented adquately to be suitable for model verification.

This study is limited to structural failure of man-made cavities in dome and bedded salts and to surface subsidence associated with sulfur mining over salt domes. These cavities result from brine production or are constructed to serve as storage facilities for a wide range of liquids and gases. Subsidence due to petroleum production and underground mining operations as well as natural subsidence are not within the scope of this report.

\subsection{Report Organization}

The next chapter describes models to analyze cavity stability and failure. The remainder of this report gives the data collected during this study. Chapters 3 through 5 give case histories of failure events. Mining and storage cavities are discussed in Chapter 3, including the la rage cavity closures at Enmininence, MS and Keil, Germany, the surface subsidences at Belle Isle, LA, Blue Ridge, TX and Grand Saline, TX and the flooding at Winnfield, LA.

Chapter 4 describes surface subsidence over mining and storage cavities in bedded salts. including those at Grosse Ile, MI, Windsor, Canada, Hutchinson, KS, and Chesire, England.

Chapter 5 describes surface subsidence due to sulfur mining including that at Fannett, TX, Sulphur Mines, LA, Hoskins:Mound, TX; Spindletop, TX and Boling, TX.

Chapter 6 summarizes the work and gives conclusions. The report concludes with an extensive bibliography related to cavity failure and to surface subsidence due to sulfur mining. 


\section{MODELING}

\subsection{Introduction}

Stability analysis of salt cavities requires a model to predict the onset of structural failure. A more sophisticated model to predict the failure sequence and post-failure geometry as well as the onset of failure is required to assess the potential for damage to other structures such as head frames, piping and other cavities. Development of such models is beyond the scope of this report; however, this chapter lists and describes capabilities of and inputs to such a model and recommends documented failure events that can be simulated to validate the model.

\subsection{Model Capabilities}

Analysis of cavity stability and failure requires a very complex mathematical model. Irregular geometries, nonlinear constitutive laws and large geometry changes require use of numerical solution techniques such as

finite element and finite difference methods.

The model must be able to simulate cavities of arbitrary shape so that usually a three-dimensional analysis is required. Occasionally, the geometry of the problem (especially cavity shape) permits a simpler axisymmetric analysis. A large-displacement, large-strain formulation that includes rigid body modes is required to predict the failure sequence.

The model must handle several different constitutive laws because of the different geological media that surround the cavities; both timedependent. and time-independent material behavior need to be modeled. Simulation of geological phenomena such as joints, fractures, interfaces, etc. is also required.

When such a model is constructed, it must be validated by predicting (a posteriori) failure events before it can be accepted for stability and failure analysis of existing and proposed cavities.

\subsection{Model Inputs}

A number of inputs are required to analyze cavity stability and to model cavity failure. Inputs required are cavity size and shape, cavity location, in situ stress, stratigraphy, formation and operating histories, 
and constitutive laws for the salt and surrounding materials. Each of these inputs is important for accurate modeling, but the relative importance of the inputs depends on the specific cavity modeled. For example, stratigraphy above the salt is not significant when modeling cavities located very deep in the middle of a salt dome.

\subsubsection{Cavity Size and Shape}

Cavity size and shape control the perturbations of the in situ stress that result in stress concentrations around the cavity. Cavity size is important for two reasons. First, stresses around large cavities are usually larger than stresses around small cavities, primarily because large cavities have large roof spans. Second, when stoping contributes significantly to the failure, large cavities can accommodate more rubble and thereby allow the cavity to migrate further towards the surface. Cavity shape is important because short, wide cavities tend to produce larger stresses than do high, narrow cavities of equal volume.

\subsubsection{Cavity Location}

Cavity depth, nearness to the salt boundaries and proximity to other cavities influence the stress in the salt and other rocks around the cavity. For example, deep cavities must support a greater overburden than do shallow cavities, cavities near salt boundaries usually induce large stresses. in the more brittle rock outside the salt and cavities in close proximity influence the stress fields around one another.

\subsubsection{In Situ Stross}

The in situ stress is the most significant factor controlling the stability and deformation of the salt cavity. Generally, the magnitude and direction of the principal stresses are unkriown. In many cases, however, it is adequate to assume that the in situ stress in the salt is lithostatic, i.e. that all three principal stresses are equal and have the same value as does the overburden. In materials that flow less readily, the in situ stress is often assumed to be a gravitating stress field; i.e. the largest (compressive) principal stress is vertical and equal to the overburden, the two horizontal principal stresses are equal and have a 
magnitude determined by the overburden and Poisson's ratiol. Other assumptions regarding the in situ stress can be made based on measured stresses.

\subsubsection{Stratigraphy}

The material above and below the cavity influence the stability and failure sequence for that cavity. The thickness and density of material above the cavity determines the overburden. More importantly, the different layers have different strengths and deform differently and therefore give rise to different failure mechanisms.

\subsubsection{Formation and Operating Histories}

Formation and operating histories are important, especially for deep cavities in which a fluid pressure must be maintained to prevent large closure of the cavity. The size and shape of storage cavities are often changed by filling and emptying cycles and occasionally these cycles cause adjacent cavities to coalesce.

\subsubsection{Constitutive Laws}

Constitutive laws define the strength and relate the stress, temperature, strain, strain rate, etc. for a material. Strength is the maximum stress a material can sustain and is usually expressed in terms of stress and material properties. An example is the Mohr-Coulomb criterion for shear failure. The relationship among stress, temperature, strain, strain rate, etc. is usually not well determined, but approximations can be made that are adequate for engineering analysis. Very little data are available to construct time-dependent constitutive models for geological materials. The most notable exception is salt, whose creep behavior can be characterized adequately by several different empirical laws. (Creep rupture is not well understood and therefore, is usually not modelled).

\subsection{Fallures Sultable for Model Validation}

Cavity failures are usually not well documented because the failed

1 The horizontal principal stress $\sigma_{H}=\nu / l-v$ ov where $\nu$ is Poisson's ratio and $\sigma_{V}$ is the vertical principal stress (equal to the overburden). 
cavity has not been mapped either before or after the event and the area around the failure has not been instrumented to measure subsidence. Therefore, engineering data needed for model validation are sparse. Data required in addition to the inputs listed in the previous section include cavity closure, closure rate, surface subsidence and subsidence rates.

Two events, whose case histories are included in the following chapters, provide engineering data for model validation. The first of these is the large closure of deep storage cavities at Eminence Dome. The case history of this event is in Chapter 3 and gives formation and operating histories, cavity size and location, and cavity closure and closure rate. The cavities are deep enough below the caprock and far enough from the edge of the dome that a constitutive model is needed only for salt. Since no surface subsidence was reported, this event should be readily simulated.

The second event is the surface subsidence over a brine field in bedded salt at Grosse Ile; Michigan. Chapter 4 gives this case history. Gradual trough subsidence was noticed 11. years before two major sinkholes formed and a number of reference points were established and surveyed periodically to provide subsidence data. Sinkhole size and shape are recorded and the stratigraphy is given. Cavity size and shape are unknown; however, they can be determined approximately using production data and location of each well and the procedures used to form the galleries from single wells. 


\section{STARILITY PROBLEMS OF MINING AND STORAGE CAVITIES IN SALT DOMES*}

\subsection{Eminence Salt Dome, Covington County, Mississippi}

Transcontinental Gas Pipe Line Corporation (TRANSCO) constructed the first natural gas storage facility designed specifically for dry natural gas storage in a Gulf coast salt dome in 1970. Fenix \& Scisson, Inc. (F\&S) was selected as the design/construction contractor: The facility has been successfully operated for over 10 years and has stored over 150 billion standard cubic feet of natural gas. The only unexpected problem resulting from the operation has been cavern closure rates. F\&S anticipated an initial closure rate of 10 to 15 percent, whereas the actual initial closure rates were between 20 to 30 percent. Recent operating data (1980-1981) indicate that closure rates have decreased to an insignificant amount. The early high closure rates were overcome by leaching additional storage. space during the off-peak storage during summer months.

Based on the experience at Eminence, the second natural gas storage project in a salt dome was constructed in 1973 and has experienced no recognizable cavern closure. This facility was constructed for Texas Utilities Fuel Co., by F\&S, in the Bethel Salt Dome near Palestine, Texas. The basic design changes (from Eminence) were: (1) cavern interval was located at a shallower depth, (2) cavern shape was changed, and (3) the minimum operating pressure was increased.

For stability purposes it should be recognized that nperating natural gas caverns "brine free" cannot be compared to operating conventional solution mined hydrocarbon caverns (such as SPR) when the caverns are operated under a full hydrostatic head of brine. ("Dry" gas minimum operating pressures vary from 0.15 to $0.30 \mathrm{psi} / \mathrm{ft}$ of depth, whereas liquid storage caverns operate under a brine head which is equivalent to $0.52 \mathrm{psi} / \mathrm{ft}$ of depth.)

Stratigraphy

The Eminence dome is located in Covington County, Mississippi, about 20 miles north of Hattiesburg. The top of the salt is at a depth of 2400 feet with an overlying caprock consisting of 500 feet of limestone and anhydrite.

*Does not include the failure of cavern No. 7 at Bayou Choctaw, which is documented in a report by J. R. Tillerson (1980). 
Figure 3.1.1 illustrates the stratigraphy of the dome. During drilling of the first well, the salt was cored continuously at the interval of 5700 to 6700 feet. These core samples were used to determine the quality of the salt and the insoluble content. Anhydrite insolubles, ranging from 0.09 to 7.42 percent and averaging four percent, were wiscovered. (See Allen, 1971, p. 278.)

\section{Site Selection}

Eminence salt dome was selected as a suitable site for the storage of natural gas because: (1) the dome is at a relatively shallow depth and is large enough to allow for future expansion, (2) wells could be constructed in the Wilcox Formation on the flank of the dome for brine disposal, (3) land for surface facilities was avallable, and (4) the site was only 1.5 miles from TRANSCO's main transmission pipeline. (Allen, 1971, p. 276; 0 il and Gas Journal, 1971, p. 67). Design criteria for the four storage cavities is shown in Table 3.1.1.

TABLE 3.1.1 Design Criteria for Eminence Storage Facility

Number of wells

Cavern interval, feet

Formation temperature, ${ }^{\circ} \mathrm{F}$

Specific gravity of gas

Maximum storage pressure, psia

Minimum storage pressure, psia

Minimum deliverability per well, Mscf/0*

Product casing size, inches

Total gas storage volume, MMscf

Cushion gas volume, MMscf

Usable (top) gas volume, MMscf
4

$5500-6200$

150

0.584

3950

1000

280

$133 / 8$

8892

2127

6765

*million standard cubic feet per day

\section{Cavern History}

Four storage caverns were leached at Eminence using the bottom injection method. In this technique, fresh water was pumped down a central 7-inch tubing string to a location near the bottom of the planned cavity. Brine was returned to the surface through the annulus between the 7 -inch tubing and a second string of 10-3/4-inch tubing placed near the top of the 


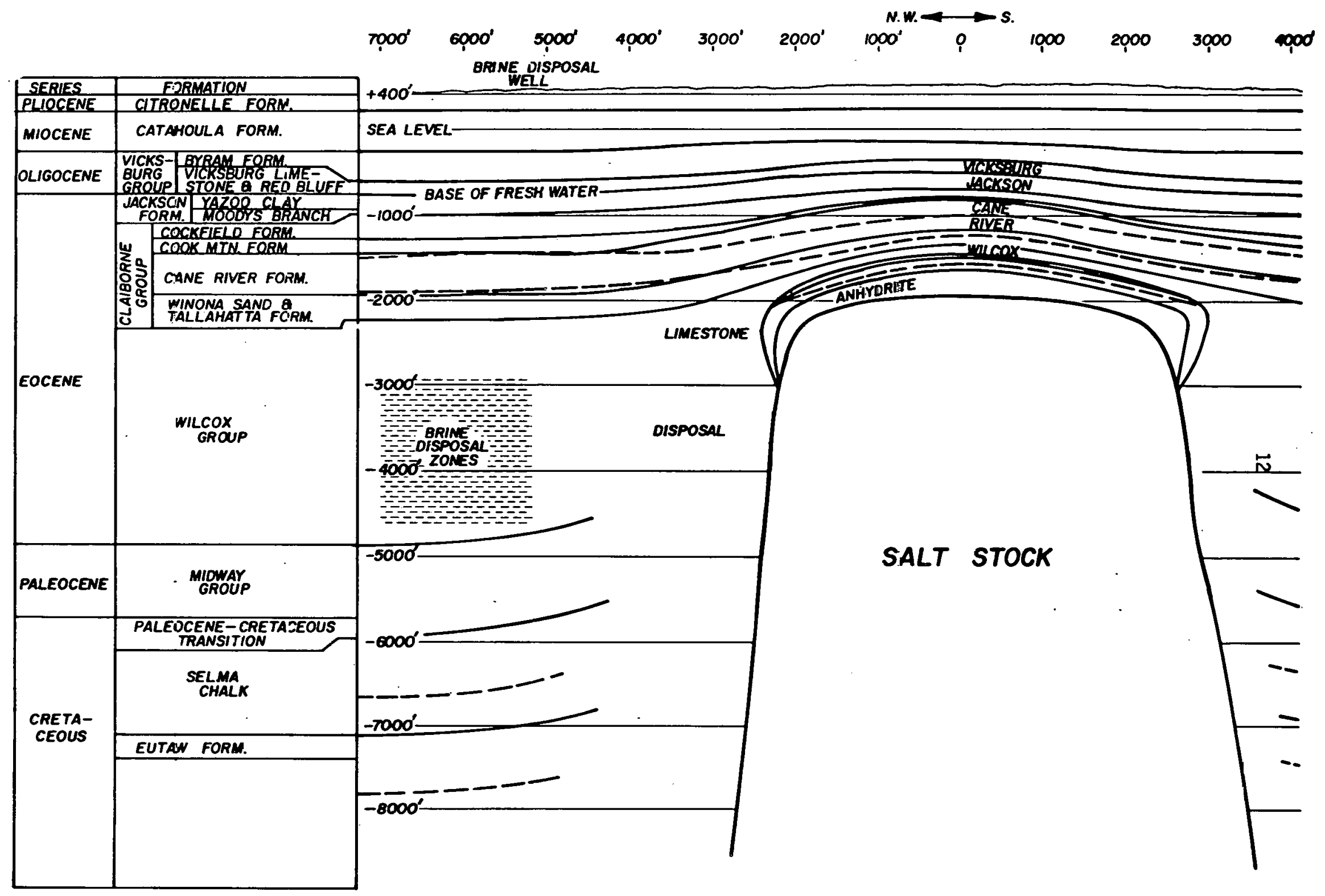

Figure 3.1.1. Stratigraphy of Eminence Salt Dome (After Fenix \& Scisson, 1980). 
planned cavity. During later stages of leaching caverns No. 3 and 4 , a modified reverse circulation procedure was used. By doing this, a brine of a higher salinity was produced, thereby leaching faster and shortening construction time. In addition, a diesel oil bianket was maintained at the top of the cavity through the annulus between the 10-3/4-inch tubing and a 13-3/8-inch casing cemented into the hole. This process preserves the cavern neck and prevents any leaching above the 10-3/4-inch tubing. (See Allen, 1971, p. 278.) Figure 3.1 .2 shows current profiles of the four caverns, as determined by sonar surveys taken upon completion of the leaching process.

The storage facilities at Eminence are dry-type (brine-free) gas storage caverns. The caverns are operated between a maximum and minimum gas storage pressure, with the gas volume between these two pressures being usable storage gas. This method of pressure storage allows free-flow of the gas from the caverns as needed and the water content of the produced gas is kept at a minimum. (See Allen, 1971, p. 277.)

The initial volume of each cavern was determined by measuring the volume of fresh water pumped into the cavern during leaching and the salinity of the brine returned. Subsequent measurements were made by metering the amount of brine or fresh water needed to fill the cavern or by measuring the amount of brine displaced when filling the cavern with gas. Sonar surveys were also run in each cavern to confirm the cavern shapes and volumes. These surveys were taken when the leaching was 50 percent complete and again upon completion. (See Allen, 1971, p. 278.)

Solutioning of cavern No. 1 began on November 24, 1968. This first cavern was completed in 393 days and had a volume of 1,100,805 barrels on December 21, 1969. Figure 3.1.3. shows the cavern pressure and volume data through Apri1, 1981. A sonar survey on March 21, 1970, indicated that the volume had diminished to 971,597 barrels*. This decreased volume of 129,208 barrels does not indicate that the cavern was experiencing closure under a full hycrostatic head of brine due to the accuracy of the sonar survey tool. On May 25, 1970, dewatering of the cavern was begun and gas

\footnotetext{
*Experience with sonar surveys of SPR caverns' shows errors in volume as large as 25 percent if the cavern shape is irregular.
} 

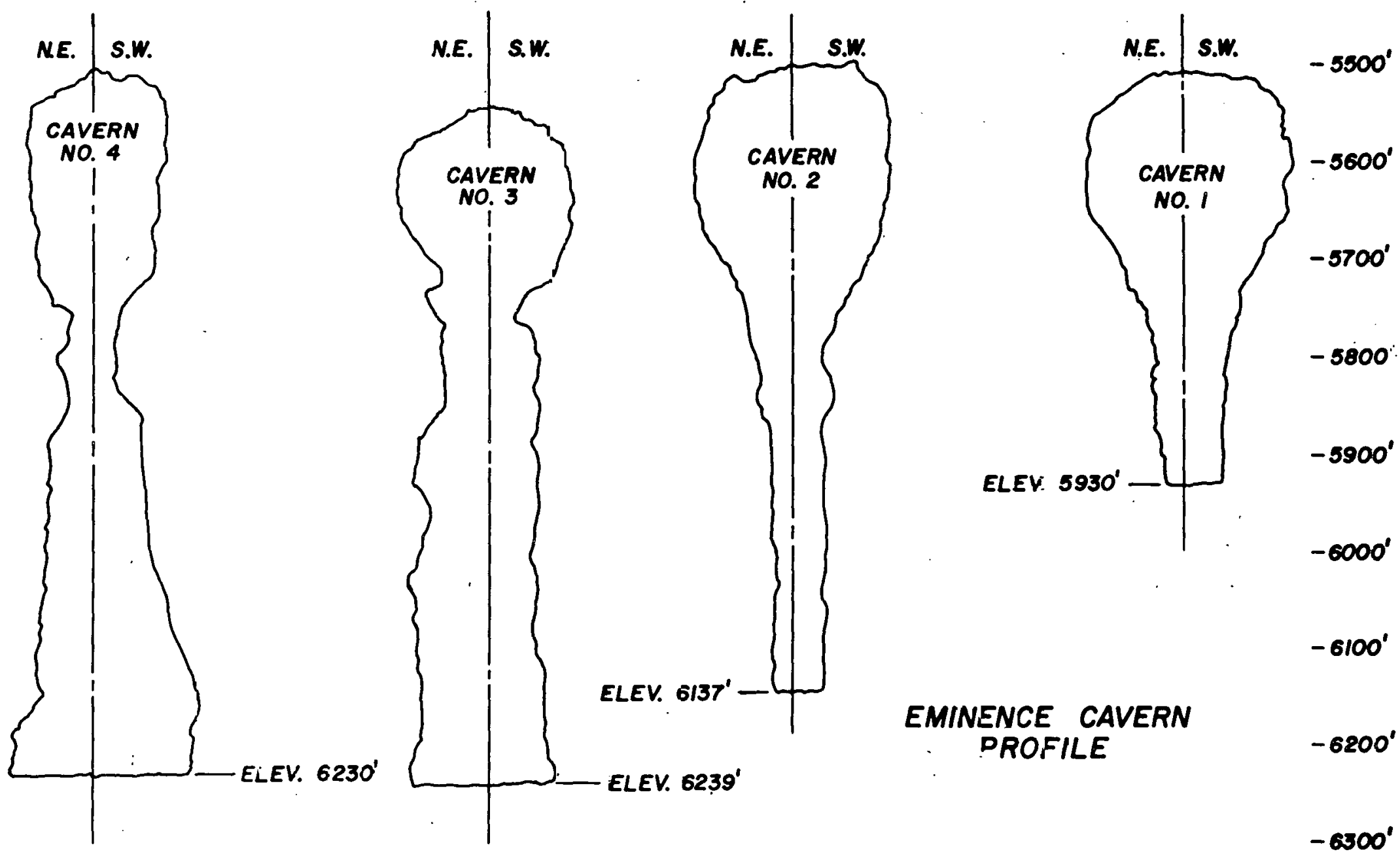

Figure 3.1.2. Eminence Cavern Profile (After Fenix \& Scisson, 1980). 


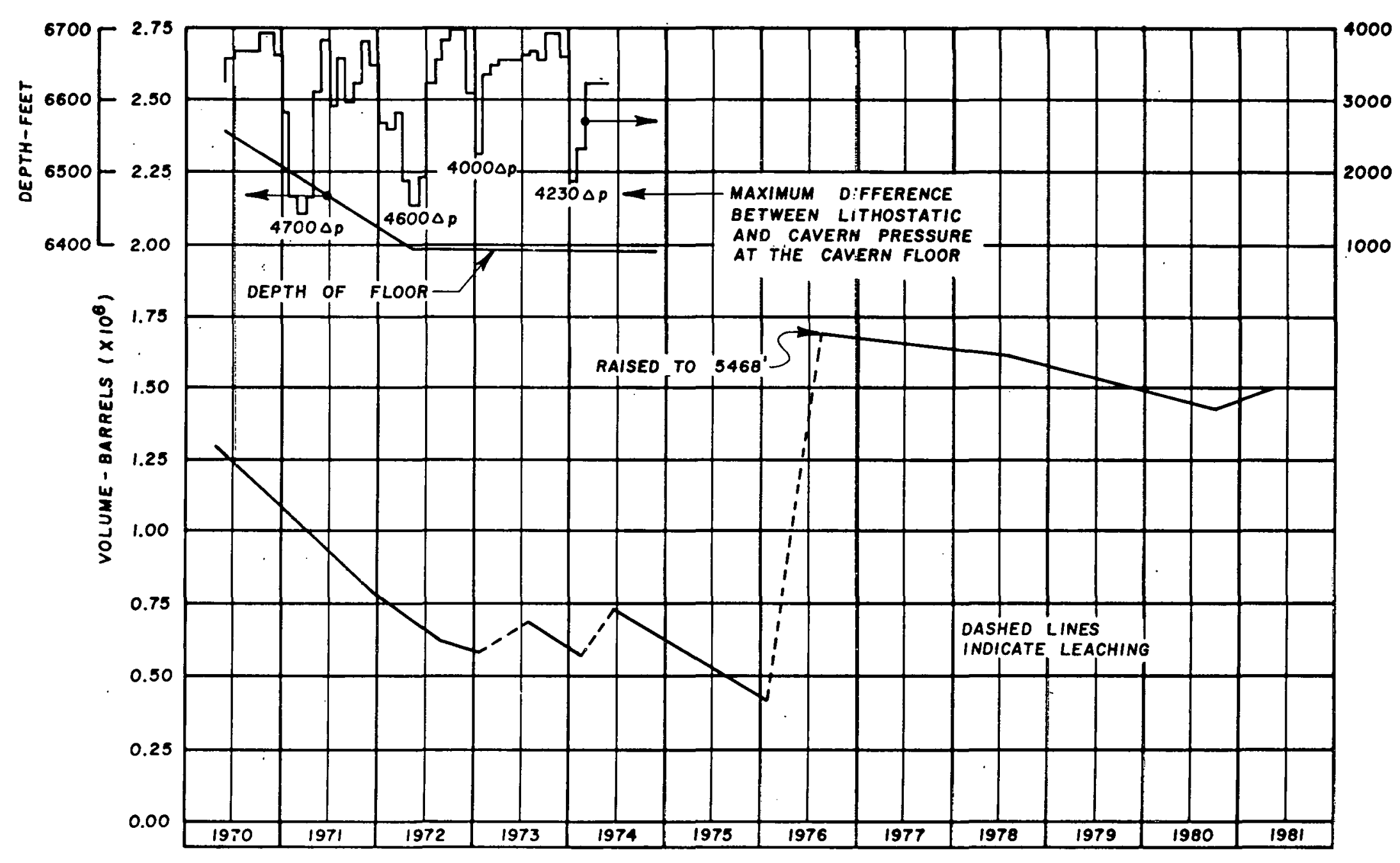

Figure 3.1.3. Volume and Pressure as Functions of Time for Eminence Cavern No. 1 (After Fenix \& Scisson, [1975]). 
was injected. Sonar measurements show that the depth to the cavern floor was 6560 feet. When the dewatering process was finished October 8, 1970, the volume estinated by metering the displaced brine was 1,047,480 burrels. When the cavern was refilled with brine from June 7,1972 , to June 23, 1972 , only 637,583 barrels were required to fill, the cavern; a loss of about 40 percent of the original volume $(24$ percent annually). During the period between October, 1970, and June, 1972, the pressure in the cavern was allowed to drop to between 2000 and 1500 psig for two periods of about three months each. The next dewatering and gas injection cycle, completed on August 24, 1972, revealed that the cavern volume had decreased slightly to 615,438 barrels, a loss of less than four peircent. At the completion of the gas injection, the cavern pressure was raised to over 3500 psig.

On January 15, 1973, the cavern pressure was reduced to below 2000 psig and injection of fresh water was started. The amount of fresh water metered in was 567,504 barrels, measured on February 1, 1973. The volume loss of 47,934 barrels indicated that some closure was still occurring. Sonar readings in the filled cavern revealed that the bottom. of the cavern was at a depth of 6393 feet, 167 feet higher than the May, 1970 depth.

The next cycle of the brine displacement and gas injection showed that the cavern volume was 691,058 barrels on July 18, 1973. Part of (about 16 percent) this increase in volume of 123,556 barrels was produced by leaching of the cavern by the fresh water that was put into the cavern during January, 1974. The remainder of the increase, however, is unexplained. The cavern was once again filled with fresh water, and the volume was 566,597 barrels on February 20, 1974. The loss of the volume of 124,461 barrels occurred when the cavern pressure dropped below 2000 psig. Subsequent brine displacement and gas injection at an increased cavern pressure disclosed a cavern volume of 739,980 barrels on June 24, 1974.

Solutioning of Eminence cavern No. 2 was started on January 31, 1969 and completed in 423 days with an initial volume of 1,102,045 barrels. Figure 3.1.4 1liustrates cavern pressure and volume through Apri1, 1981. The pressure and volume history is similar to cavern No. 1. When brine displacement and gas injection was completed. in December, 1970, the amount of volume lost was less than two percent. By the end of March, 1973, fresh water metered into the cavern showed that about 44 percent (corrected for sum fillup) of the cavern volume had been lost. During this period, the 


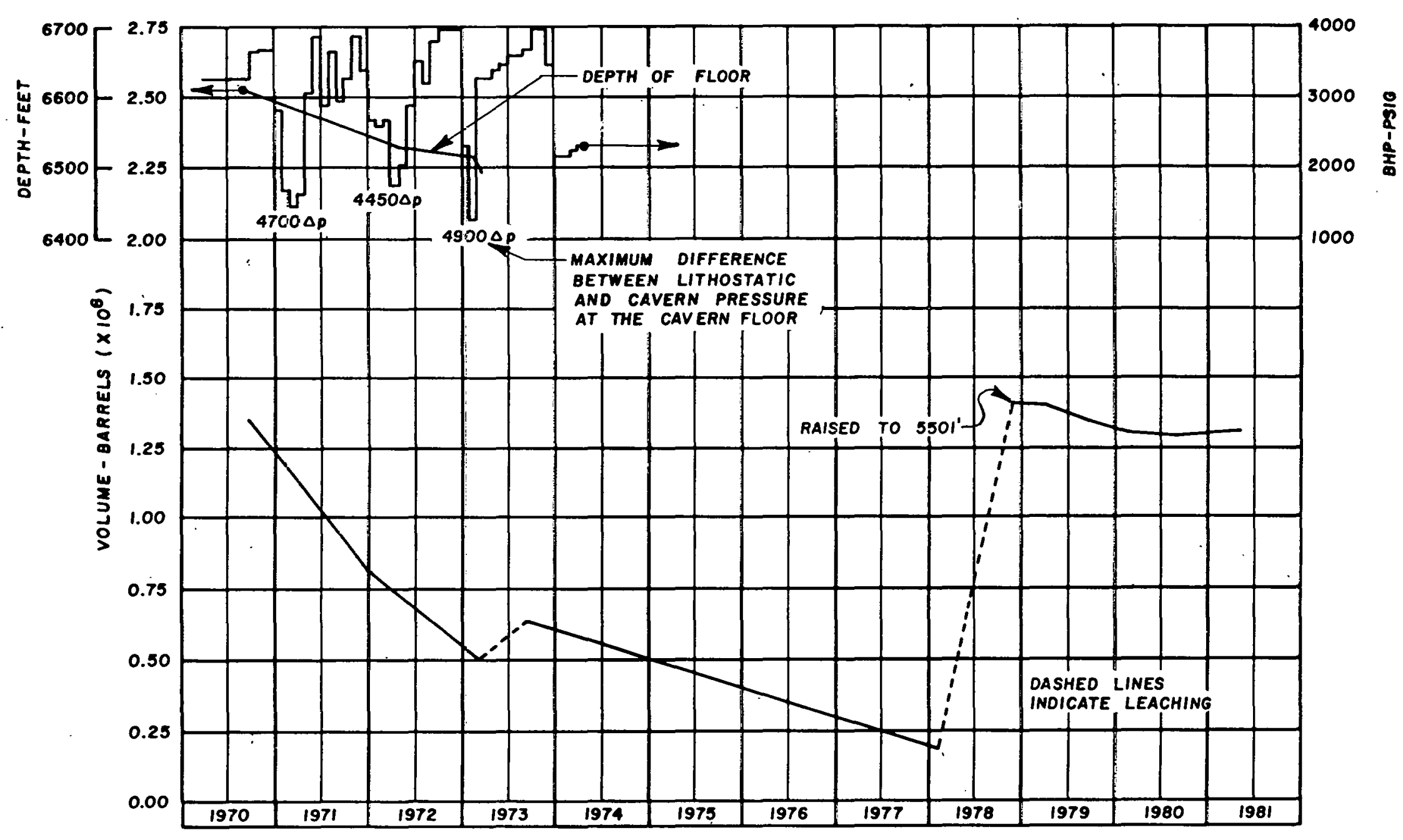

Figure 3.1.4. Volune and Pressure as Functions of Time for Eminence Cavern No. 2. (nfter Fonix \& Scisson, [1975]). 
pressure in the cavern had been allowed to drop to between 1800 and 1300 psig for three periods of three, two, and one month, respectively.

Subsequent filling of the cavern with fresh water caused some leaching of the cavern. The final volume, after brine displacement and gas filling, in September, 19i3, was 64\&,249 barrels.

Cavern No. 3 had a metered volume of 2,178,872 barrels when placed into service August 27, 1972. Cavern No. 4 had a volume of 2,119,738 barrels upon completion of leaching on January 16, 1972. Figures 3.1 .5 and 3.1 .6 show the pressure and volume data through Apri1, 1981, for these caverns. Both caverns experienced maximum closure during periods of low pressure.

All of the caverns constructed in the Eminence salt dome are presently different in size and depth as shown in Figure 3.1.2. Since the completion of the caverns, major closure was initially experienced in each cavern. The wellhead pressures of the four caverns at Eminence are normally the same; however, at times they are different. Each cavern experienced its greatest amount of closure during the periods of low pressure. The pressure and volume curves also show that the floor of each cavern decreased in depth. with time due to upward movement of the salt in the floor or sluffing of the salt walls. Subsequent leaching also occurred in each cavern when fresh water was injected.

The most recent data reflect a dramatic decrease in losses as can be seen in the Figures 3.1.3 through 3.1.6. The diminishing of these losses can be attributed to: (1) maintaining a higher minimum cavern pressure over extended time periods; (2) the fact that no dewatering has been required in approximately two years which could tend to case harden the salt face itself; (3) the sphere-like ${ }^{\star}$ cavern configuration of caverns No. 1 and 2 which reduce the ratio of vertical to horizontal diameter, making these caverns more stable; and (4) the installation of additional injection gas cooling.

The last survey run to verify inventories shows a volume gain of some 4.5 percent; however, this may be somewhat inasked by the fact that the downhole pressure and temperature instruments were used for the first time

\footnotetext{
*The initial stresses in rock salt are hydrostatic; therefore, the best shape from the standpoint of stability is a sphere. Therefore, reducing the ratio of vertical to horizontal diameter will make the cavity more stable.
} 


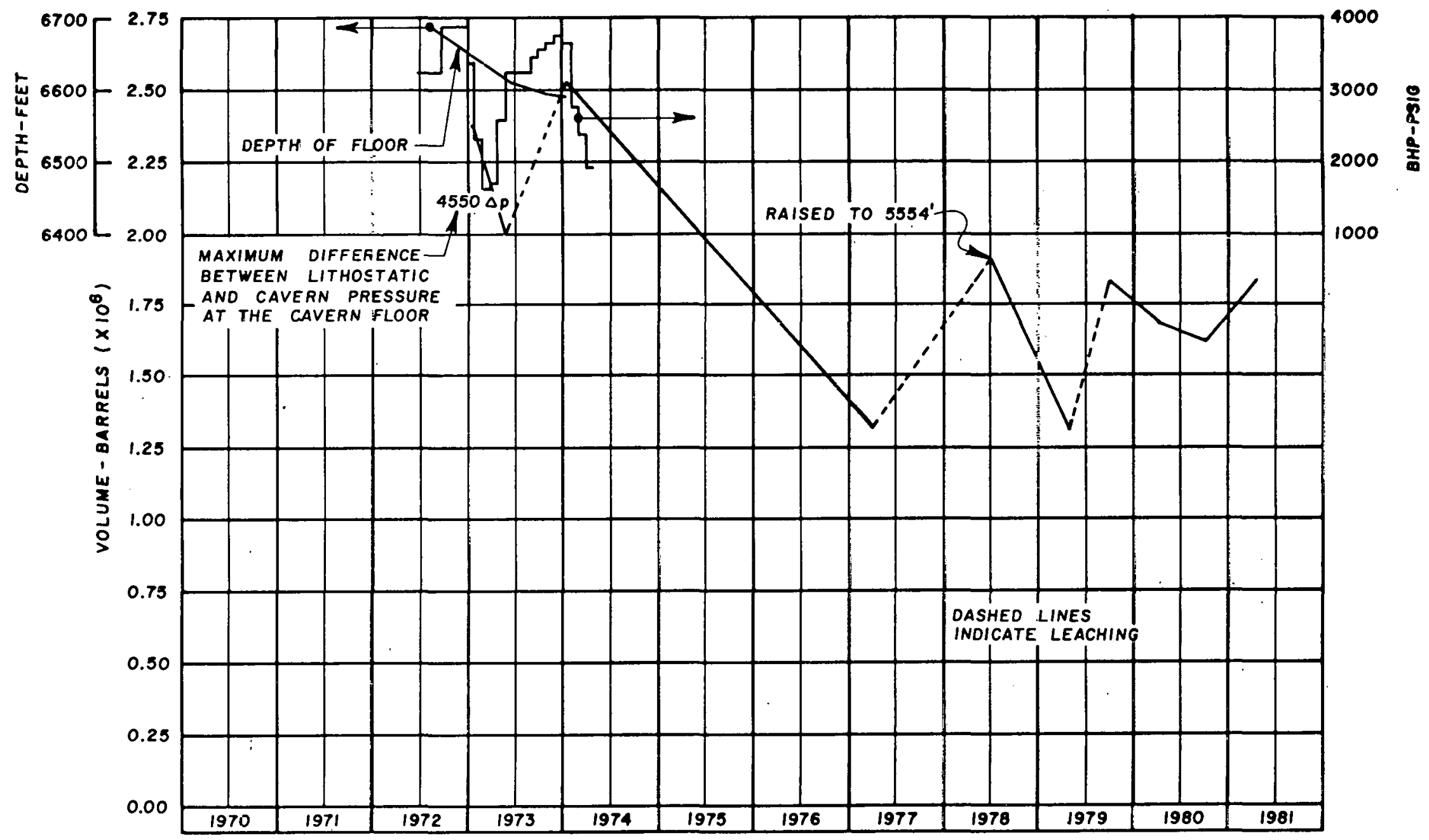

Figure 3.1.5. Volume and Pressure as Functions of Time for Eminence Cavern No. 3 (After Fenix \& Scission, [1975]).

$\bullet$ 


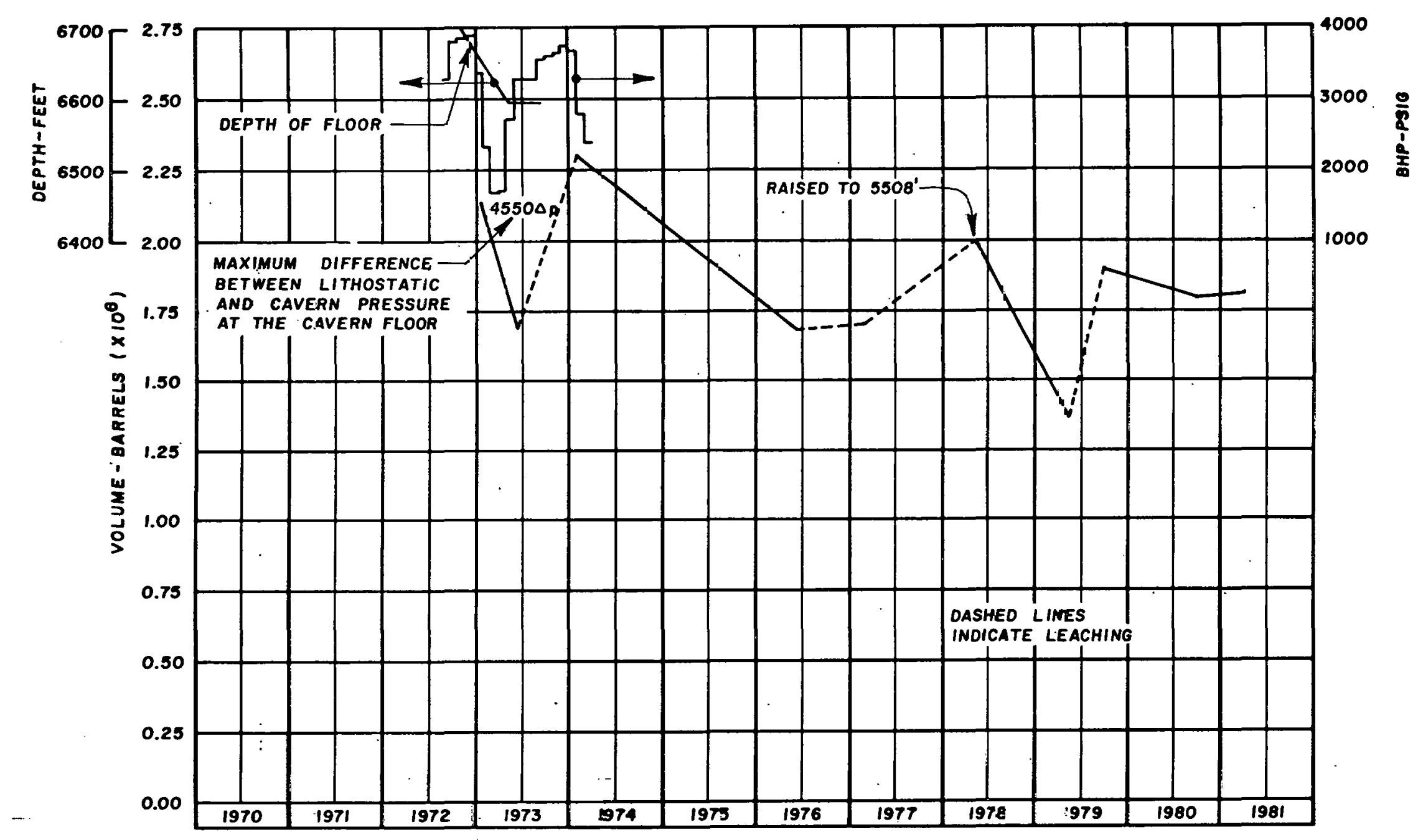

Figure 3.1.6. Volume and Pressure as Functions of Time for Eminerce Cavern No. 4 (After Fenix \& Scisson, [1975]). 
since recalibration. Additional testing will be needed to confirm this trend.

Overall, recent data, technique of operations, and inventory calculations and procedures point to future losses that would be classified as minimal.

The closure percentages and closure volumes reported in this article are not actual cavern closure rates, i.e., they are a combination of actual cavern closure and water volumes remaining in the bottom of the cavern that are unrecoverable. The bottom portion of each cavern is filled with salt, anhydrite, and brine. In the past, it has besn determined that it is not economical to attemipt to drill to the original cavern total depth, displace the water in the "rubble pile", and reutilize this volume as usable gas storage space. 


\subsection{Keil 101 Storage Cavern}

Introduction

A gas storage cavern in West Germany, Kiel 101, also experienced excessive loss of storage volume, apparently due to creep closure of the cavern. This cavern was leached at a depth of about 4500 feet. Before this cavern was put into service, a series of experiments was performed to verify analyses and laboratory experiments on scale model cavities. Data from the analyses and laboratory testing were used to predict the life of the cavern. Results of the tests performed on the cavern shnw that tn obtain the desired cavern life requires that the minimum pressure in the cavity be greater than that projected on the basis of analytical and 1 aboratory studies.

\section{Stratigraphy}

Haselgebirge salt is encountered at a depth of 3880 feet and extends down to the 4431 foot level where it comes in contact with the Zechstein salt. The Haselgebirge salt contains approximately 22 percent impurities, primarily red clay. The Zechstein formation lies below the Haselgebirge and is relatively pure Upper Permian rocksalt.

\section{History}

In 1965, Stadtwerke Keil, under supervision of Deutsche Erdol Aktiergesellschoft (DEA), initiated plans for construction of a gas storage cavern in the Bramstadt salt structure which is located south of Keil, Germany. Preliminary investigations determiner that it was feasible to leach a cavern at a depth between 4297 and 4641 feet, with a usable volume of 1,236,025 cubic feet. (See Brandt and Nair, [1969], p. 3-4.) A cavern at these depths has its roof in the Haselgebirge salt (impure) and its floor in the Zechstein salt (pure). After completion, surveys indicated that the cavern was located at a depth between 4280 and 4592 feet. Röhr (19/3, p. 94) records the initial net volume of the cavern as 1,398,474 cubic feet and a total volume of $2,401,420$ cubic feet. Insolubles, primarily red clay from the Haselgebirge salt, accumulated at the bottom, causing the difference between the net and total volume, as planned. It was estimated that $1,871,695$ cubic feet of salt had to be dissolved to 
create this cavern. (See Brandt and Nair, [1969], p. 5.) Cavern volumes were determined by sonar surveys.

C. T. Brandt with Keshavan Nair (1969) and Hans Ulrich Röhr (1973) have investigated the operations at the Keil 101 storage cavern. The following is a summary of the data contained in these reports.

\section{Storage}

The cavern was constructed with the intention of storing gas composed of approximately 50 percent hydrogen and 18 percent $\mathrm{CO}_{2}$, which is manufactured in the fractionation of butane (Brandt and Nair, [1969], p. 5). This gas mixture was to be stored at pressures below 2000 psi, which is approximately the dew point of the gas.

\section{Cavern Leaching}

It was intended that a small cavity, at depth greater than 4431 feet, would first be solutioned into the Zechstein rocksalt. This cavity was to act as a receptical for the insoluble material of the Haselgebirge formation (Brandt and Nair, [1969], p. 3). Prior to leaching, the borehole was filled to the 4428 foot level with gasoline. Figure 3.2.1. shows the casing and tubing locations when leaching began. When approximately 353,150 cubic feet of salt had been removed, a sonar survey indicated that a cavity of 311,088 cubic feet had been created. (See Brandt and Nair, [1969], p. 4.)

Operations ceased at this time because of a pump failure. Sonar surveys indicate that 80 percent of the solutioning occurred above the 4428 foot level in the Haselgebirge salt. From this it was apparent that the protective blanket had not remained in place. (See Brandt and Nair, [1969], p. 4.)

Brandt and Nair ([1969], p. 4) indicate that when the tubing was removed, it was discovered that the two lower lengths had fallen off. A sonar survey of the cavity indicated that the intended floor of the cavity had been raised by approximately the length of these two tubing sections.

When leaching was started again, leakage around the pipes hampered the establishment of a gasoline blanket below the 4280 foot level. Chemical additives were added to increase the gasoline viscosity and a blanket was 


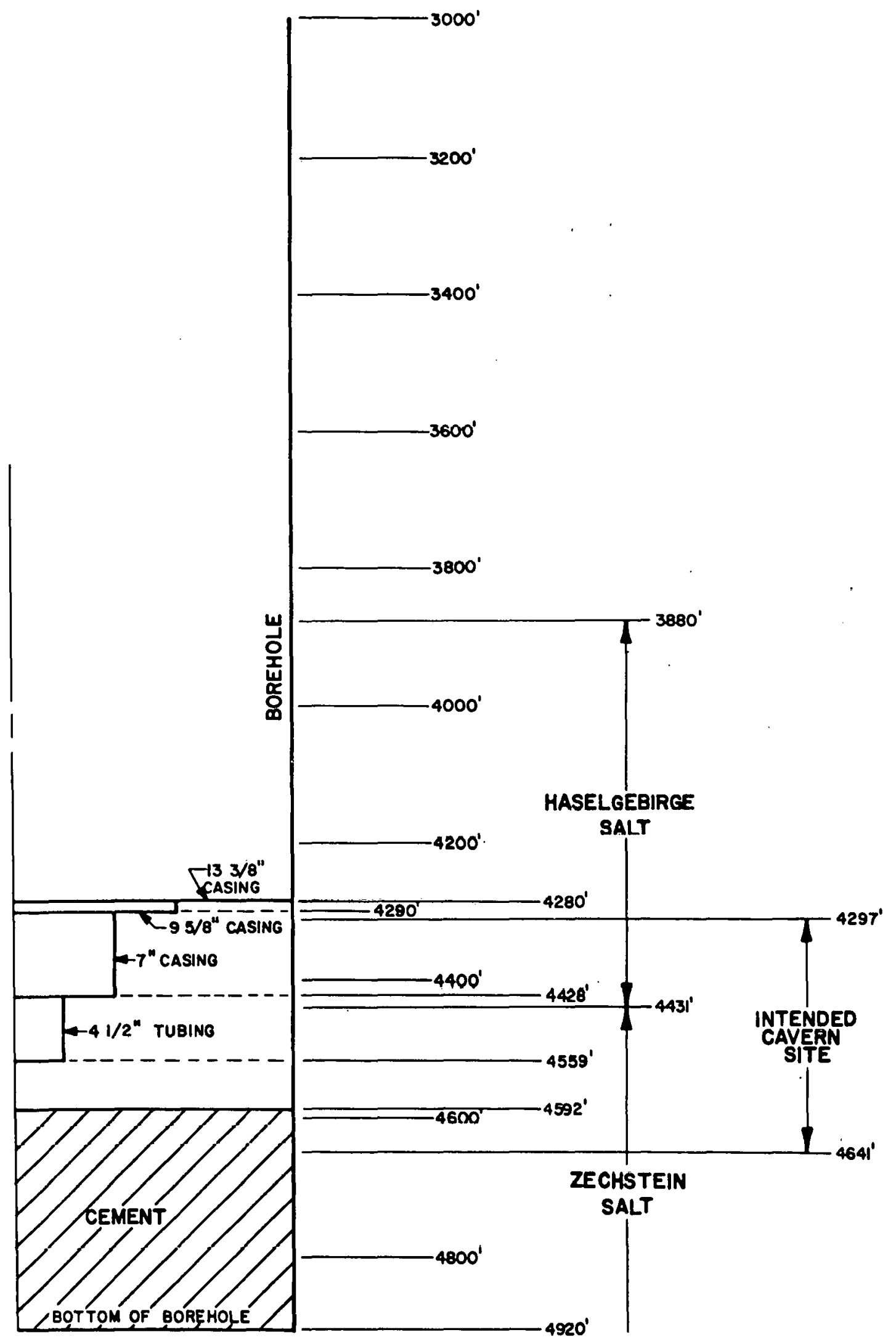

Figure 3.2.1. Casing and Tubing Geonetry When Leaching Began at Keil 101. 
established down to the 4306 foot level (the end of the 7" casing). By the addition of 5 gallons of gasoline per day, the desired blanket level was maintained. (See Brandt and Nair, [1969], p. 4.)

On October 24, 1976, a usable cavern volume of approximately 1,398,474 cubic feet was attained and solutioning ceased (Brandt and Nair, [1969], p. 5). Baar (1977, p. 147) describes the shape of the cavity as resembling an inverted pear, with the lower portion filled with insolubles.

\section{Pumping Process}

Since a pressure of over 2500 psi was required to displace the brine and the dew point of the gas mixture intended to be stored in the cavern was only 2000 psi, it was determined that the brine would have to be pumped out before the gas could be pumped into the cavity. Several attempts during the three years following the solutioning were made at emptying the cavity. Initial pumping began on October 28, 1967, with a pump being suspended at the 4290 foot level (the end of the 7-inch casing). After 90,053 cubic feet of brine had been removed, the pump failed. A sonar survey of the cavern was taken after pump failure occurred and showed that a major portion of the cavern roof had collapsed and that a reduction in volume of about 250,000 cubic feet had occurred (Baar, 1977; p. 149; Brandt and Nair, [1969], p. 5). This is about 18 percent of the original volume.

Before the pump failed, there were several indications of cavity closure. The first is that the metered volume of brine pumped out of the cavity and the change in volume of brine in the cavity indicated by change in brine level were inconsistent: much more was pumped out than the drop in brine level indicated. Second, when the brine level dropped to about 1800 feet below the surface, it held constant for twelve hours even though brine was being pumped out at the rate of 560 cubic feet per hour. This was followed by a twelve hour period in which the brine level actually rose while pumping continued at the same rate.

After several more attempts to pump the cavern dry, the brine was finally removed by displacing it with gas. The cavern is now being used, but at a much higher operating pressure than originally planned. The minimum pressure in the operating cycle is 1450 psi (R8hr, 1973, p. 10). 


\section{Closure Data}

Figure 3.2.2. plots cavern volume, brine (water) removed and brine level as functions of time for the period October, 1967 to February, 1970. The brine level is a measure of the pressure in the cavity: saturated brine has a density of about $1.2 \mathrm{~g} / \mathrm{cm}^{3}$ so that the head increases at the rate of 0.52 psi per foot.

Figure 3.2.3 plots brine level in the cavity as a function of time during three different periods. The three curves show that the rate at which the brine level rises decreases with time. This decrease is due to two phenomena. First, as the level rises, the pressure in the cavity goes up, reducing the shear stress and therefore the creep rate in the salt. Second, even at constant cavity pressure, the creep rate would decrease because the salt hardens during the initial phase of creep (transient creep). These data, coupled with the cavern geometry given in Figure 3.2.4, can be used to calculate cavity closure at various depths in the cavity.

As reported for the caverns at Eminence, closure of the Keil 101 storage cavern shows the need to maintain fairly high cavity pressure to prevent substantial loss of storage volume. Creep of salt must be considered when determining cavity operating pressure and cavity life. 


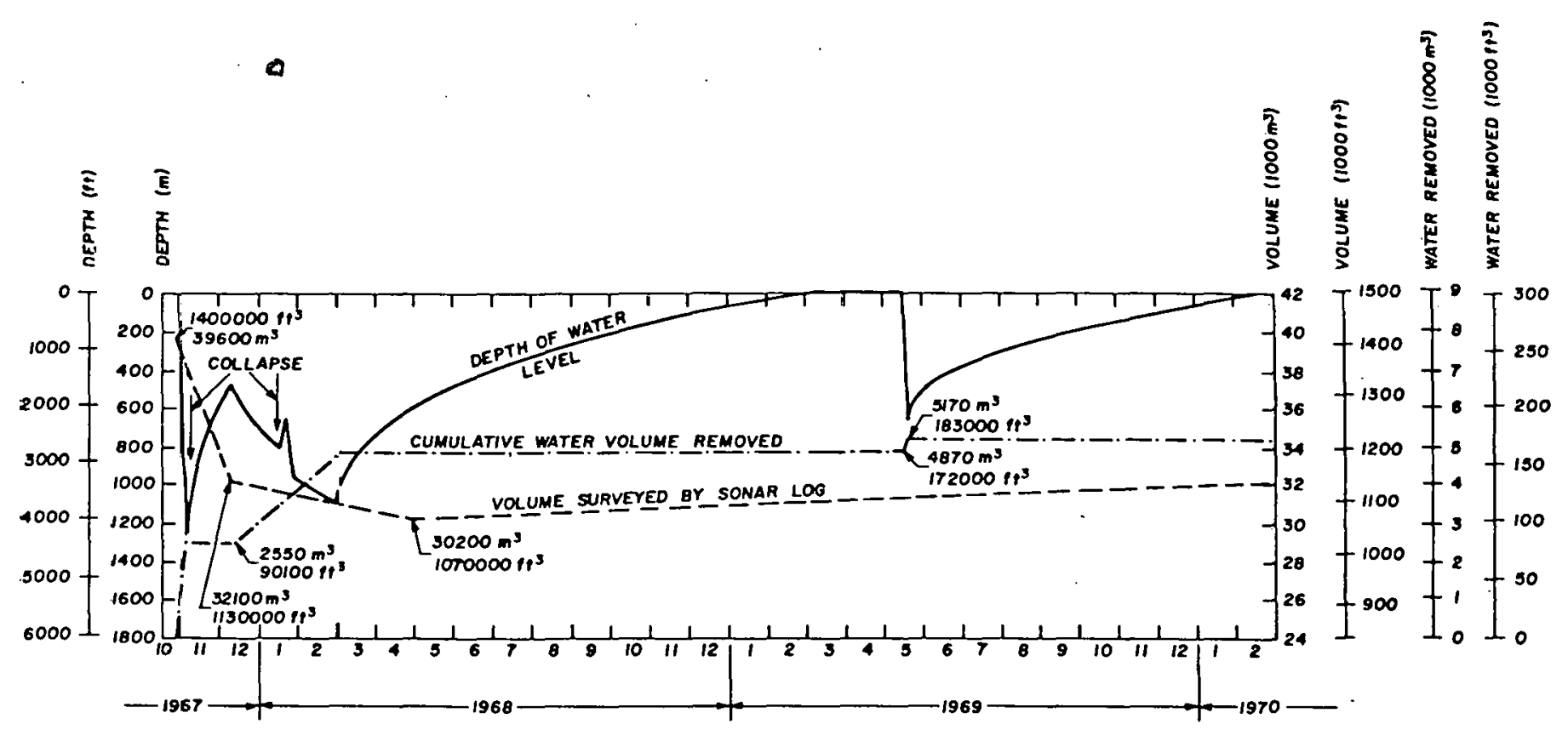

Figure 3.2.2. Volume Change, Water Removed and Water Level as a Function of Time for the Keil 101 Storage Cavern (After Röhr, 1974, p. 95). 


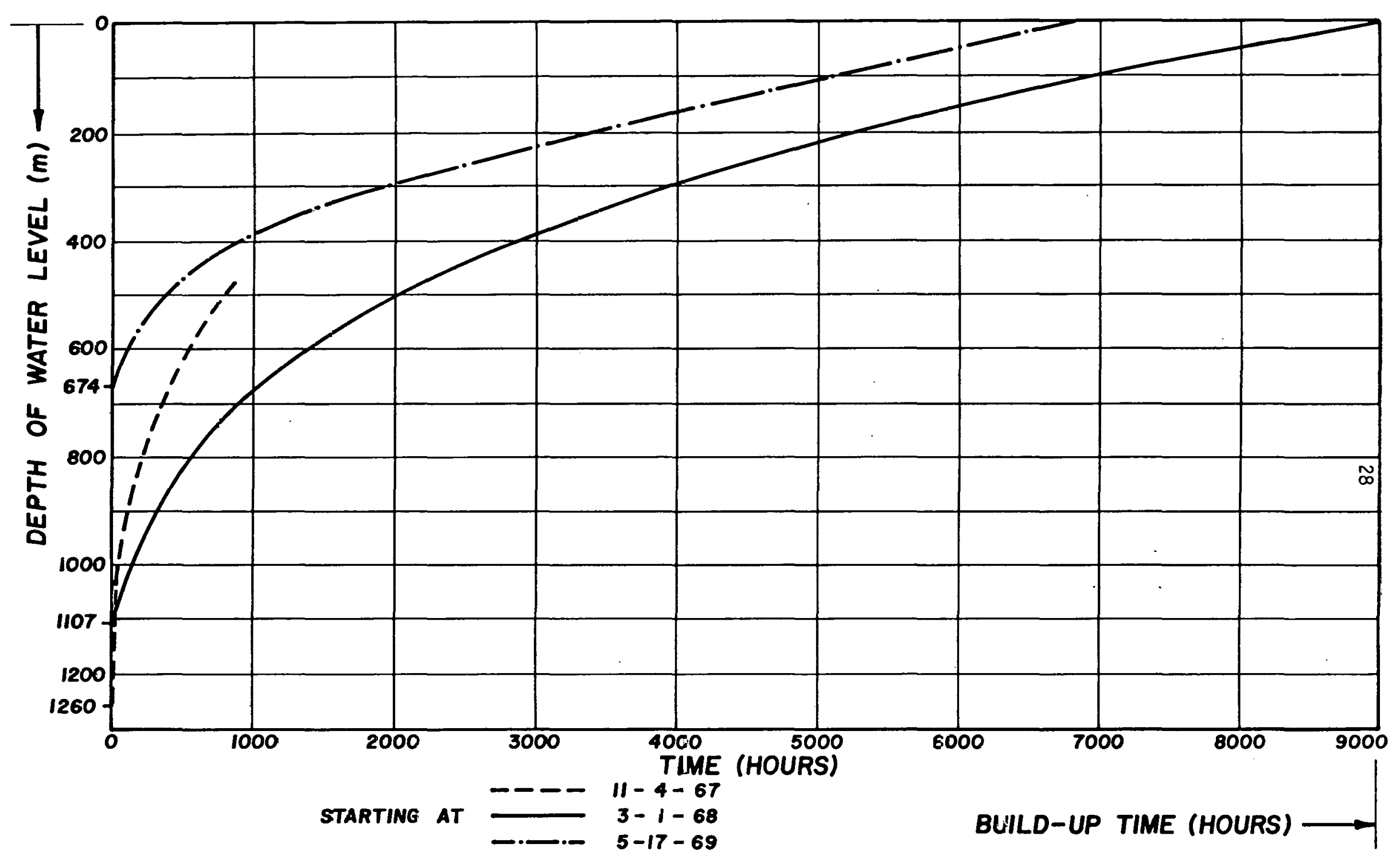

Figure 3.2.3. Depth of Water Level as a Function of Time for the Keil 101 Storage Cavern (After Röhr, 1974). 


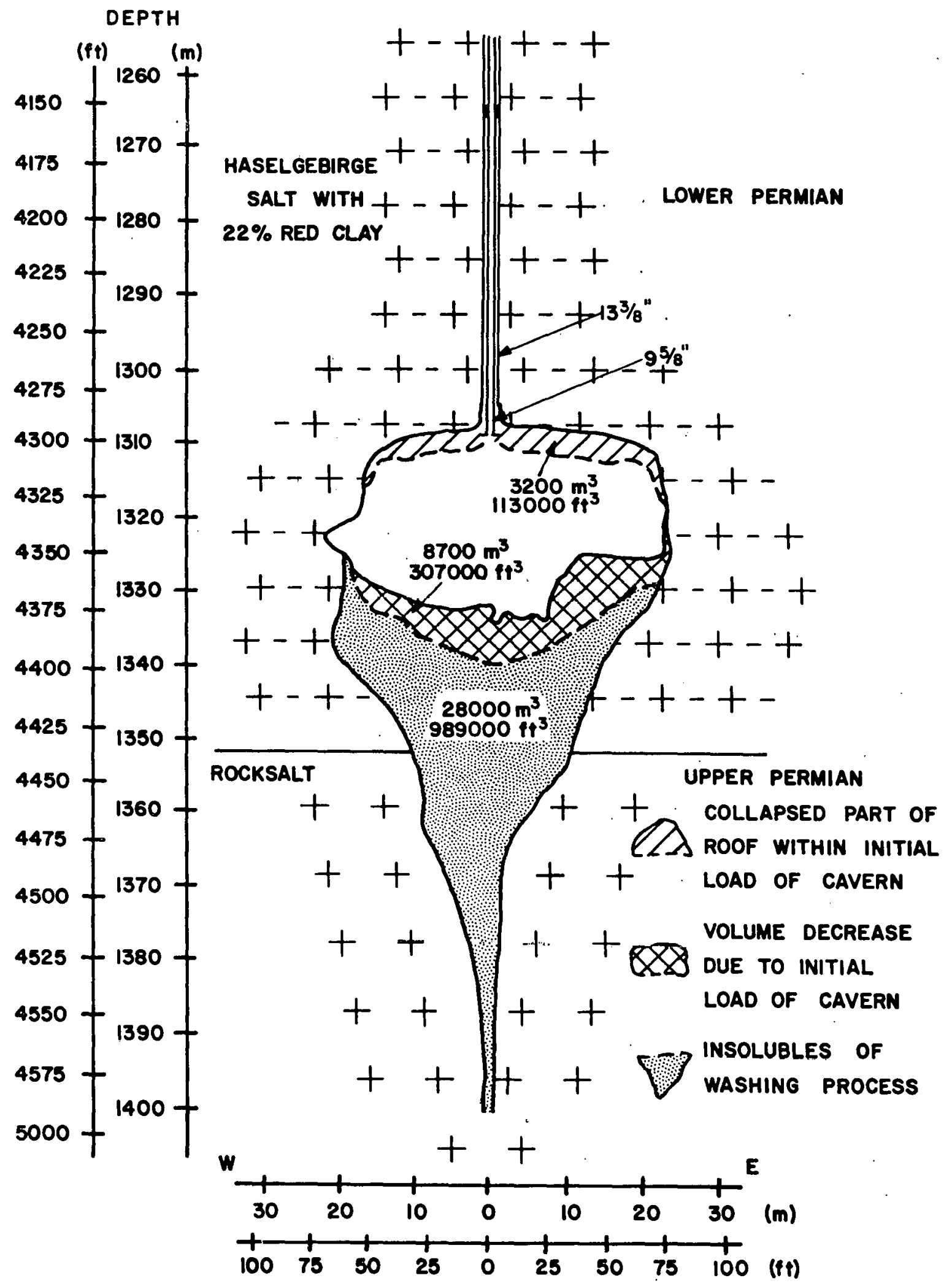

Figure 3.2.4. Cross Section of Keil 101 Storage Cavern Indicating Volume Loss Due to Collapse and Closure (After Röhr, 1974, p. 94). 


\subsection{Belle Isle Salt Mine, St. Mary Parish, Louisiana}

\section{Introduction}

In March, 1973, a sinkhole 200 feet across and 50 to 60 feet deep formed at Cargill Company's Belle Isle salt mine apparently caused by a leak in the mine's No. 2 shaft lining let in tons of mud, sand, and water. No injuries occurred and operation of the mine was not disrupted, but appreciable damage did result.

$\underline{\text { Geology }}$

The Belle Isle salt dome is located in St. Mary Parish, Inuisiana, on the shore of Atchafalaya Bay. It is the most southeasterly dome of Louisiana's historic "five islands". Topographically it is characterized by a mound which rises to a height of 80 feet above sea level (Barton, 1931, p. 1335). The dome is the result of salt intrusion into Tertiary and Quaternary sediments of the Gulf Coast geosyncline. Approximately 300 to 500 feet of caprock covers the top of the dome.

\section{History}

Salt was discovered on Belle Isle by Captain A. F. Lucas in 1896. An exploratory well was drilled in an attempt to inrate and deccribc the contour of the salt mass and also to test for oil and gas deposits (Plimpton and uthers, $197 \dot{9}, \mathrm{p} .10)$. Salt was discovered in this first well at a depth of 373 feet (Vaughan, 1926, p. 384). Around 1900, two shafts were sunk in unsuccessfull attempts at rock salt mining. One of the mines was flooded when the underground workings penetrated the flank nf the dome. Problems controlling saturated sand at the 250 foot level just above the salt caused abandonment of the other. shaft. Dangerous petroleum gases were encountered while sinking one of these shafts. Additional wells were drilled during 1916 and 1917 in search of sulfur, and again in 1921 to 1925 exploring for both oil and sulfur. (See Plimpton and others, 1979, p. 10.) The Freeport Sulphur Company conducted a geophysical survey from 1929 to 1930 which resulted in adandoning the dome as a source of sulfur or oil (Barton, 1931, p. 1336, 1338).

In the 1930's oil drilling operations by Sun $0 i l$ Company were 
successful, resulting in the present-day Belle Isle Field (Plimpton and others, 1979, p. 10). Cargill, Inc., began sinking a shaft for underground salt mine development in 1961 and reached the top of the salt at 172 feet. Salt production was started in 1963 at the 1163 foot level. This mine shaft is 1000 feet from the northern edge of the salt. (See Paine and others, 1965, p. 617.)

Another shaft was completed using conventional methods at the Belle Isle salt mine in December, 1970. This No. 2 shaft is to a total depth of 1225 feet and is 380 feet southwest of the No. 1 shaft. The No. 2 shaft was constructed to be used as an emergency exit, an intake airway, and to handle large equipment. (See Plimpton and others, 1979, p. 12.)

Problems with this No. 2 shaft were apparently first identified on February 27, 1973, when a chimney-shaped opening (150 feet in diameter and 30 feet deep) developed behind the shaft lining (Kumar and Hoda, 1978, p. 155). An unusual amount of water was found at the bottom of the shaft. On the northwest side of the shaft at the bottom of the concrete liner a flowing stream of water was discovered. Attempts to stop the water flow by grouting proved unsuccessful. On March 8, 1973, ground tremors were felt and surface subsidence occurred. The developing sink was located 40 feet south-southeast of the No. 2 shaft. Underground inspections after the event dispelled the initial belief that a large amount of water had entered the mine. (See Plimpton and others, 1979, p. 12.)

Approximately 24 hours after the first subsidence, a second, larger subsidence occurred. This movement caused the total collapse of the shaft. The tightening and breaking of the rope guides was the first indication of this ns.rurrence. The next 10 to 15 minutes witnessed the disappearance of numerous buildings and equipment down into the shaft, including the 65 foot headframe. The resulting sinkhole was about 200 feet in diameter and 50 to 60 feet deep. (See Plimpton and others, 1979, p. 12.)

Cargill evacuated the mine immediately following the collapse. The site was watched continuously for the next few days. The mine was then reentered through the No. 1 shaft for recovery and explorative purposes. Calculations by the Bureau of Mines indicated that approximately 38,000 cubic yards of material and 1,500,000 gallons of water had entered the mine. Future plans for the mine were made by Cargill, which included filling the crater with sand and recovering the No. 2 shaft. This would be 
accomplished by filling and stabilizing the surface and freezing the surrounding ground before sinking the shaft again through the frozen ground. (See Plimpton and others, 1979, p. 13.)

Court litigation between the mine owners and the company that sank the No. 2 shaft, Cargill and Cementation Company, respectively, is currently in progress concerning the occurrences at Belle Isle salt mine recounted here. These proceedings have thwarted attempts to obtain detailed data that may exist on the 1973 subsidence. 


\subsection{Blue Ridge Salt Dome, Fort Bend County, Texas}

\section{Introduction}

On December 24, 1949, a sinkhole formed where salt solutioning operations were in progress at the Blue Ridge sal.t dome. Hanna ([1958], p. 12) believes that the caprock above the solutioned cavity collapsed, resulting in the formation of a surface sinkhole having an approximate diameter of 150 feet and depth of 35 feet. Plant structures were damaged at the time of the collapse.

\section{Stratigraphy}

Blue Ridge salt dome is located in Fort Bend County, Texas, 15 miles southwest of Houston. The salt stock extends. 1.5 miles along a NW-SE axis and 1 mile at right angles to this. Depth to the salt at the top of the dome is approximately 150 feet. This dome is characterized by two flattopped surface mounds, 3500 feet apart, which rise approximately 20 feet above the surrounding plains. The highest part of the salt stock is located between these mounds. Caprock consisting of limestone and gypsum interbedded with salt overlies the dome. This caprock has its greatest thickness at the center of the dome and thins towards the flanks. Various beds of sands, clays, gravels, shales and limestone overlie the caprock. (See Hager and Stiles, 1925, pp. 306-311.)

\section{Mining Operations}

Data relating to the mining operations at $B 7$ ue Ridge are minimal. The mine was located on the Blue Ridge. Prison Farm and was operated by Gulf Salt Company, which has since been absorbed into the United Salt Company. Underground mining operations began in the thirties and were later converted to a brining operation during the mid- to late-forties. A 24-inch shaft was established to mine the salt and was later used as the pipe shaft for the brining operations of the fortles (Hanna, [1958], p. 12). In Figure 3.4.1, Hanna ([1958], p. 14) diagrams a cross-section of the upper portion of the dome in which the cavern was located. This diagram shows that the entire cavity was created within the top 200 feet of the salt with the roof being located very near the top of the salt. 

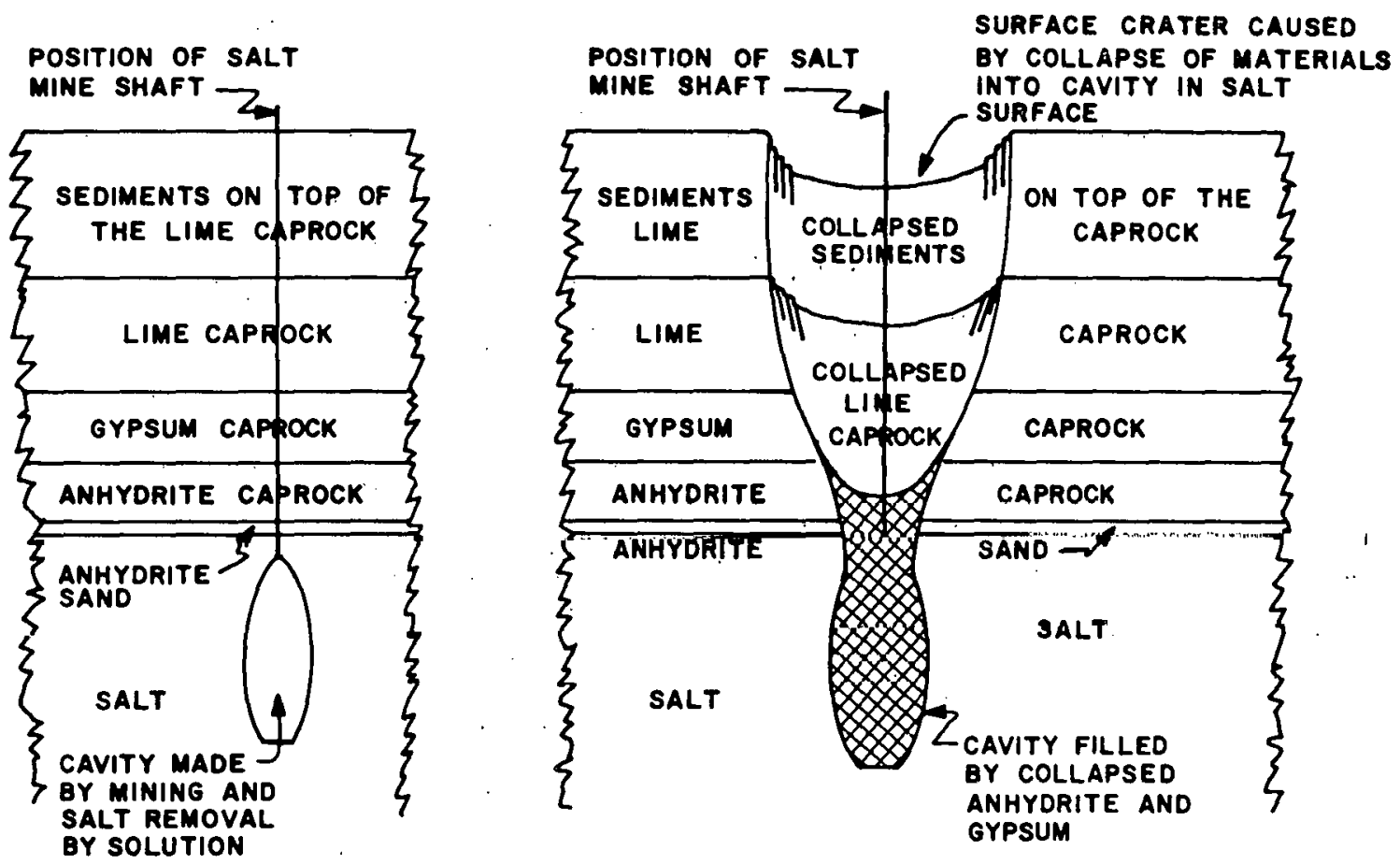

A - Before collapse

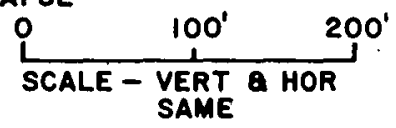

B - AFTER COLLAPSE

Figure 3.4.1. Diagrammatic Section of the Blue Ridge Salt Mine Prior to and After the Collapse of 1949 (After Hanna, [1958], p. 14). 


\section{Subsidence Data}

Prior to the collapse, which occurred on December 24, 1949, Hanna (1953, p. 277) reports that machinery at the plant began to malfunction. This was unexpected because the plant had been shut down for the Christmas holiday. On December 24, the ground above the solutioned cavity started to sink. Hanna reports that the subsidence was centered around the pipe shaft through which the fresh water and brine was being pumped in and out. By December 28, when Hanna (1953, p. 277) visited the site, the sinkhole had stabilized with a diameter of 150 feet and an approximate depth of 35 feet. Since the sinkhole was partially filled with water or brine, the actual depth was hard to establish. During Hanna's visit, he noted that surface cracks were found encircling the sinkhole. Structural damage to plant buildings also occurred. The buildings that were damaged were located in the area directly above the solution cavity and some portions of the plant fell in with the overlying strata.

\section{Mechanisms}

The apparent reason for the collapse is that leaching of the salt occurred too $\mathrm{close}$ to the salt-caprock interface, leaving a relatively small; if any, salt roof for the cavity. Hanna ([1958], p. 12) reports that the brining operations breached the cavern roof resulting in a surface subsidence.

\section{Data Release}

Gulf Salt Company, which has since been merged into United Salt Company, was operating the site at the time of the collapse. Records relating to the operation, production rate and details of the collapse are on file with United Salt Company, but it is against company policy to release this information. 


\subsection{Grand Saline Salt Dome, Van Zandt County, Texas}

\section{Introduction}

The Grand Saline salt dome is located in Van Zandt County, Texas, 65 miles east of Dallas. Solution mining during the early and mid 1900's has resulted in the formation of several sinkholes. The latest of these sinks, which will be described below, occurred in April, 1976, leaving a hole with an approximate diameter of 125 to 130 feet and depth between 60 and 70 feet (Figure 3.5.1).

\section{Stratigraphy}

The Grand Saline salt stock resembles an elliptical truncated cone and is 1.25 miles wide and 1.50 miles long; slightly elongated along the northsouth axis. Depth to the top of salt varies from 210 to 340 feet. (See Fisher, 1965, p. 310.) Overlying the stock is a 5-foot-thick, brinefilled bed of cavernous anhydrite. Limestone, also containing brine-filled cavities, lies above the anhydrite and is encountered at a depth of about 190 feet. This limestone and anhydrite is not considered to be a true caprock since it is cavernous and found to be missing over many parts of the dome. Unconsolidated sand and clay beds constitute the remaining strata with one exception; between the 39- and 44-foot level a bed of water-bearing sandstone is found. (See Taylor, 1930, p. 580.)

\section{Subsidence and Surface Effects}

Between 8:00 and 8:30 a.m. on April 27, 1976, a sinkhole began forming near the intersection of 01 eander and Tremont streets in Grand Saline, as shown in Figure 3.5.2. The May 6, 1976, issue of the Grand Saline Sun reports that when first observed, the width was 4 feet by 10 feet. Depth at this time was not reported. Within 1.5 hours, the diameter had increased to 75 feet and the depth was estimated at 60 to 70 feet. The final dimensions of the sinkhole were 120 to 125 feet wide and 60 to 70 feet deep (Grand Saline Sun, May 6, 1976). Brine filled the lower portion of the hole, up to the 25 foot level. Surface cracks were observed up to 65 feet away from the edge of the sinkhole (Grand Saline Sun, April 29, 1976). These cracks can be seen in Figure 3.5.3. As the strata overlying 


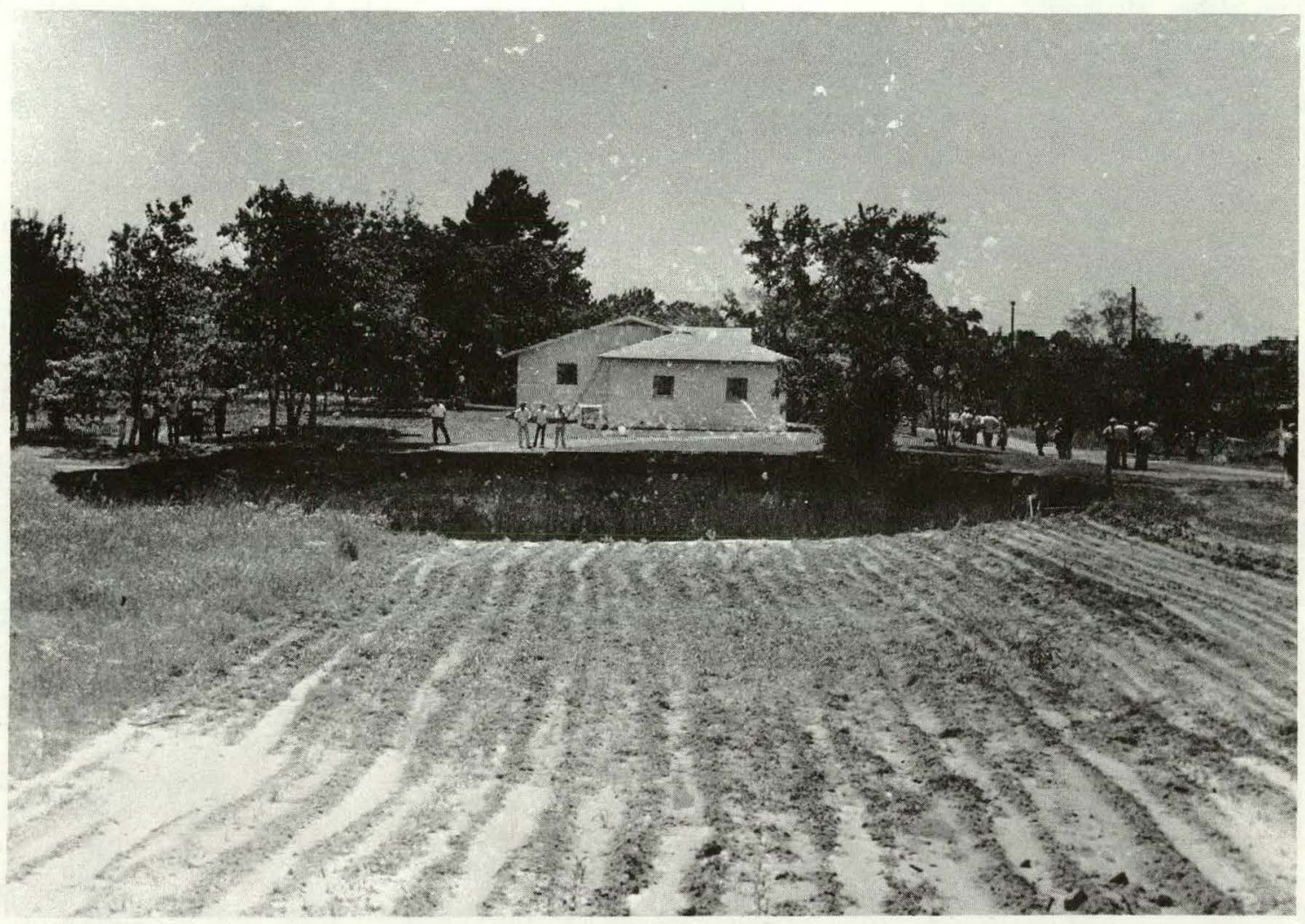

Figure 3.5.1. Overview of the Sinkhole that Appeared in Grand Saline, Texas, on Apri1 27, 1976. The Diameter is Approximately 125 to 130 Feet. (Photo courtesy of Howard Wooda11, Grand Saline Sun, Grand Saline, TX, 1976.) 


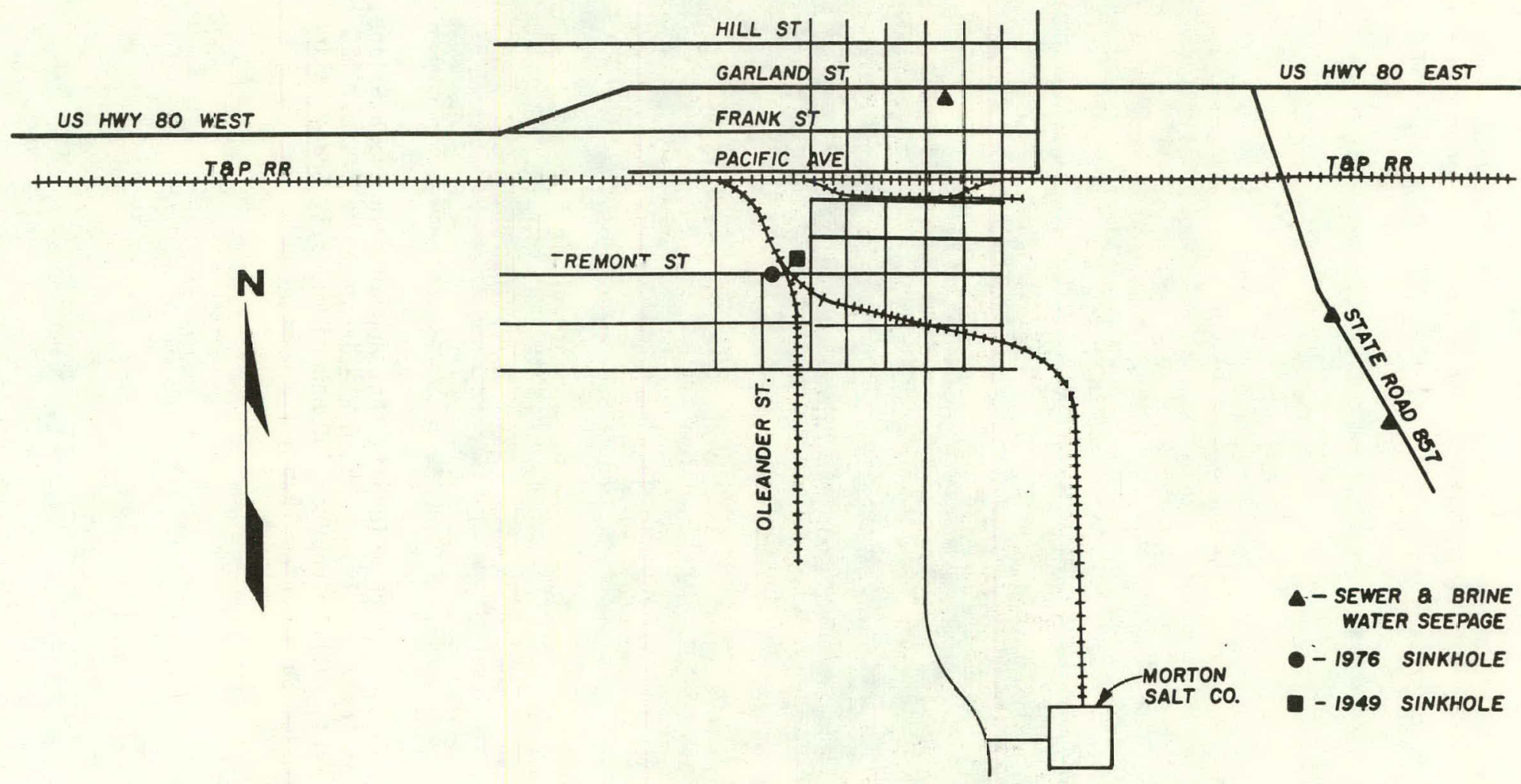

Figure 3.5.2. City Map o $=$ Grand Saline, Texas, Showing Approximate Locations of Sinkholes and Area where Brine and jewer Water Seeped to the Surface During the 1976 Collapse. Sinkhole to the Left of the Tracks occurred in 1976, and that to the Right of the Tracks Jccurred in 1949 (Modified after Cnamber of Commerce, Grand Saline, TX). 


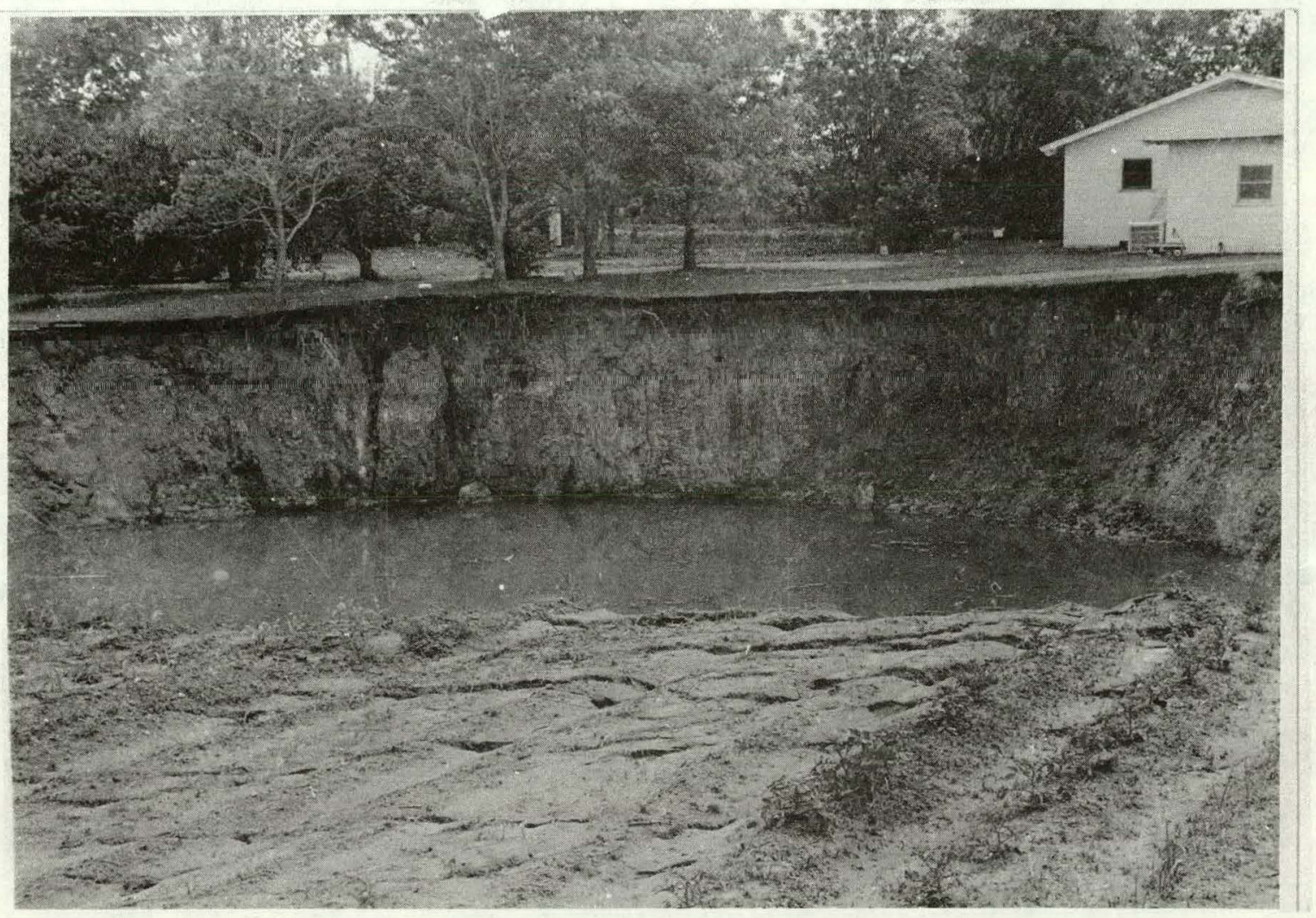

Figure 3.5.3. Photograph Showing Surface Cracks Around the 1976 Grand Saline Sinkhole (Photo courtesy of Howard Wooda11, Grand Saline Sun, Grand Saline, TX, 1976). 
the cavern collapsed, brine and sewer water seeped out of the ground in three areas, as shown in Figure 3.5.2.

Several days prior to the subsidence, people living in the vicinity could hear the underlying strata collapsing into the cavity. This suggests that the subsidence mechanism was stoping.

\section{Mechanisms}

Two differing opinions as to the cause of the sinkhole have been formulated. The first cites the solution mining practices of the early 1900 's as the underlying cause of the collapse. In this vicinity, brine was extracted from the saturated zone above the dome. B. W. Carrington \& Co., Fielder Sall CO., and Southern Salt Co. operated brine wells in this area. Powers and Hopkins (1922, p. 220) indicate that natural brine was simply pumped from wells sunk 100 to 200 feet into the salt. The majority of these wells were abandoned in the early 1900's. The 1976 subsidence apparently occurred above a cavity that was created by one of these wells. The subsidence may have been triggered by an increase in the overburden weight caused by a leaking sewer line and by a large rainfall (11 inches in 24 hours). The sewer line was buried approximately 25 feet below the surface and was engulfed by the sinkhole (FIgure 3.5.4). When the subsidence occurred, sewage and brine seeped out of the ground at locations as far as 1.5 miles from the sinkhole. This suggests that the sewer line had been leaking for a long period and that the sewage reached the porous anhydrite layer over the salt.

The second opinion (USGS, [in press]), postulates that the collapse occurred above a cavity created by Morton Salt Company's well No. 2, which was operated between 1921 and 1919 and was scaled in 1950 by plugging the borehole with 50 feet of cement. This well was drilled approximately 180 feet into the salt and solutioning then proceeded. This solutioning produced a morning glory shaped cavity which dissolved the salt up to the salt-anhydrite interface, leaving no salt roof (USGi, [in press]). The cavity subsequently collapsed through an upward stoping process.

This view holds that collapse of the overburden was enhanced by the weakening of the overlying strata that resulted from alternating periods of high rainfall followed by dry spells. No reference to the leaking of a sewer line is made in this view. 


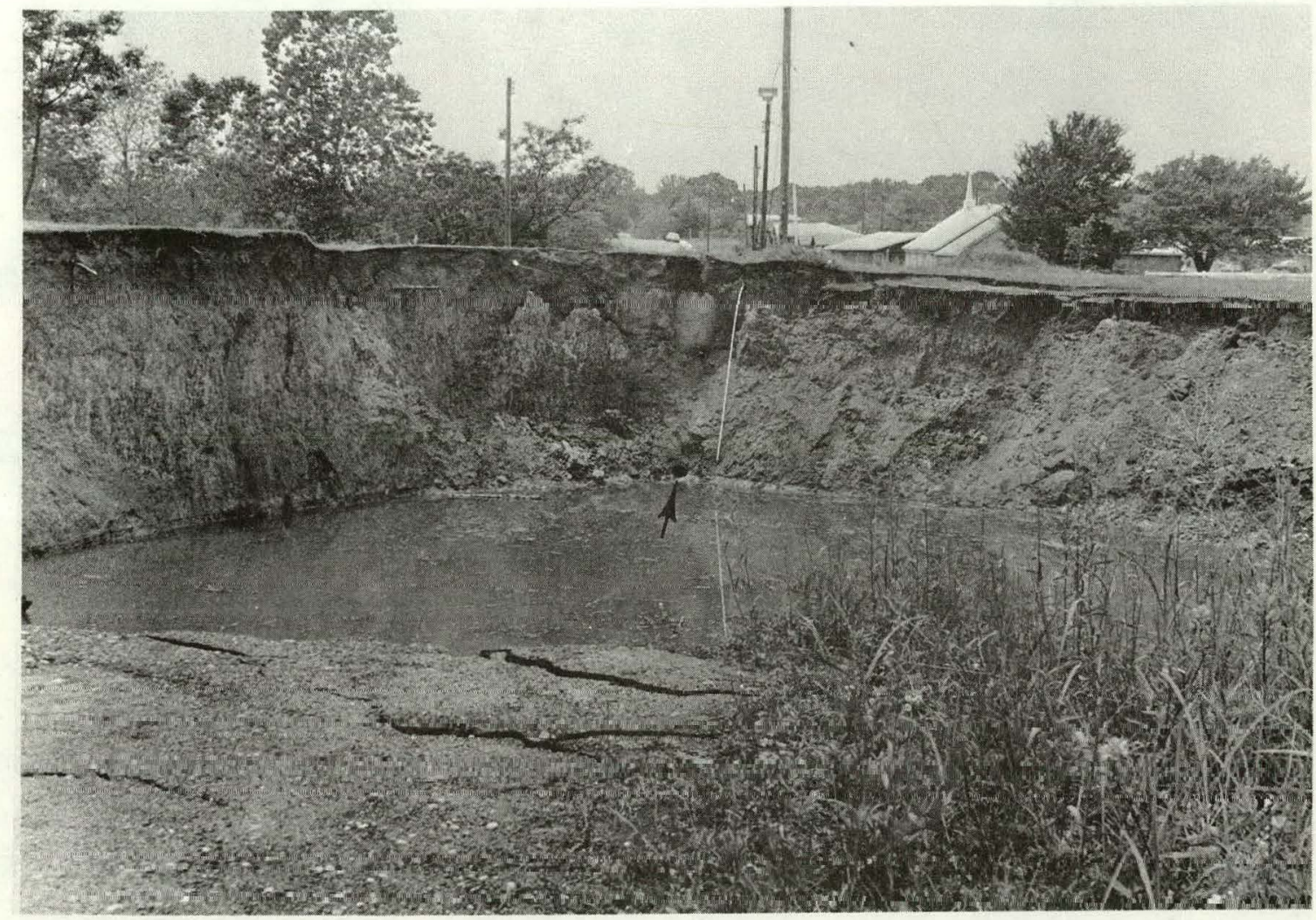

Figure 3.5.4. Photograph Showing the Location of the Sewer Line in the 1976 Grand Saline Sinkhole. (Photo courtesy of Howard Wooda11, Grand Saline Sun, Grand Saline, TX, 1976). 


\section{Other Occurrences}

A previous sink in 1949 had occurred in the immediate vicinity, only approximately 200 feet east of the 1976 sink (Figure 3.5.2). This collapse occurred around a brine well that was in operation at the time and completely destroyed the well. This sinkhole was approximately the same size as that of 1976. City officials indicated that sinkholes have occurred at other times. They also feel that since extensive solutioning has occurred in that area, subsidence features may occur at any time. 


\subsection{Winnfield Salt Dome}

Introduction

In 1965, excessive amounts of water leaking into the underground salt mine at Winnfield caused abandonment of operations in the mine. Water from the cavernous caprock seeping through the salt at a point of close approach to the mine appears to have been the basic cause.

\section{Location and Statigraphy}

The Winnfield salt dome is approximately 5 miles west of the town of Winnfield, Louisiana, along U.S. Highway 84 . The dome has a surface outcrop of calcite caprock, covering approximately 100 acres. The salt dome itself is about one mile in diameter. The top of the salt is encountered at about 300 feet below sea level. The natural topography of the dome has been modified by man's activities. A quarry, operated by Winn Rock, Inc., lies atop the dome. A lake, dump material, and various buildings also occupy some of the dome's area (Figure 3.6.1). Figure 3.6.2 shows a geologic section of the Winnfield salt dome. The salt is overlain by anhydrite ranging in thickness from a few feet to over 300 feet. Contact between the salt and anhydrite layers contains large natural solution cavities through which water flows. Approximately 20 to 50 feet of gypsum overlie the anhydrite, and 20 to 75 feet of limestone overlie the gypsum. (See hoy and others, 1962, p. 1444-1445, 1448.) Various data indicate that parts of the caprock have collapsed at different times from the natural solutioning of the upper portion of the salt plug. These data include: (1) the irregular contacts between the anhydrite, gypsum, and limestone layers, (2) the fractured and contorted appearance of the calcite cap rock, and (3) the irregular orientation of the carbonaceous bands in the calcite. (See Belchic, 1960, p. 32.) A complete description of the Winnfield structure is included in two reports by Hoy and others (1962) and Belchic (1960). 


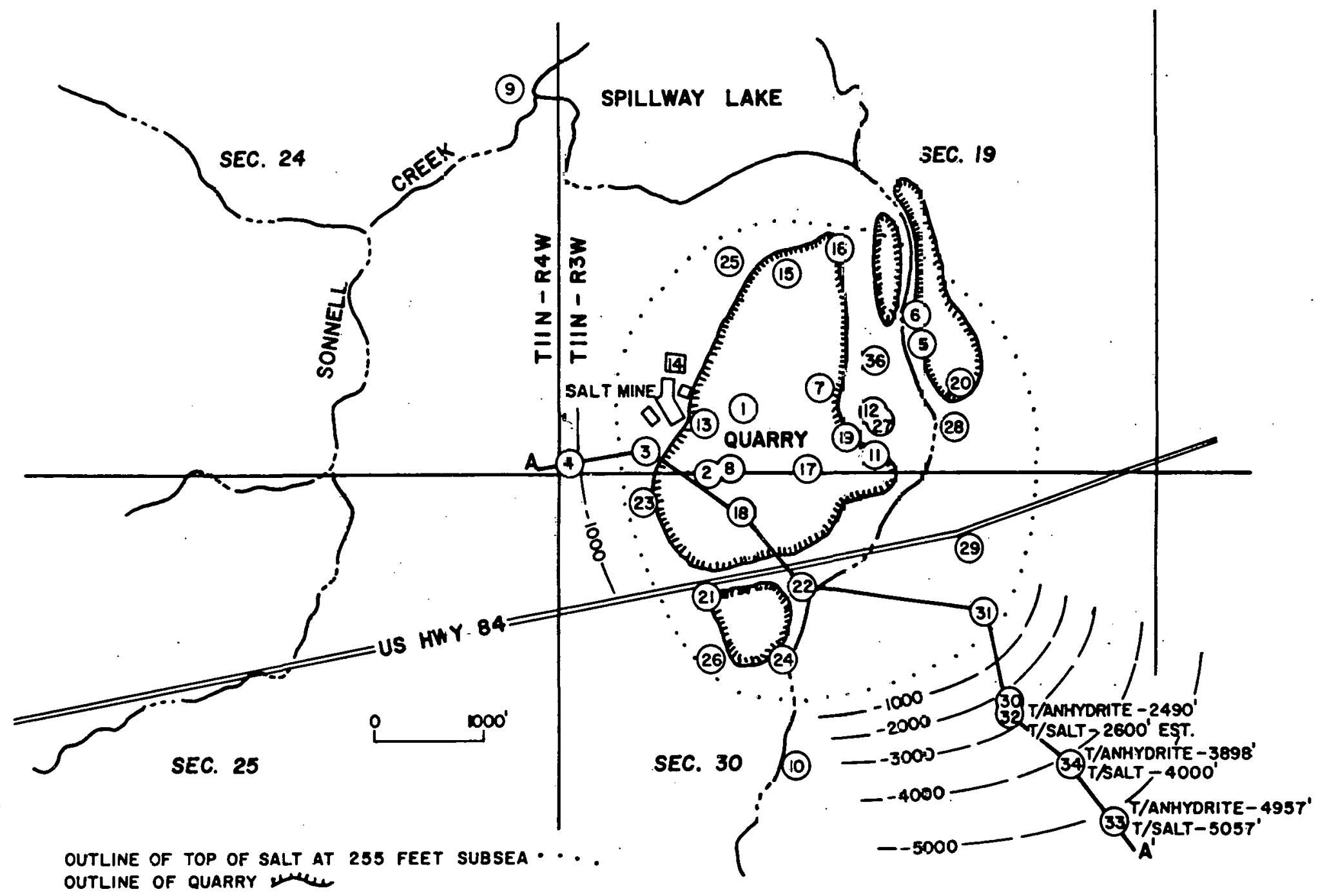

OUTLINE OF QUARRY HEL

STRUCTUAAL CONTOURS TOP OF SALT - -

Figure 3.6.1. Topographic View of Winnfield Salt Dome (A־ter Belchic, 1960). 


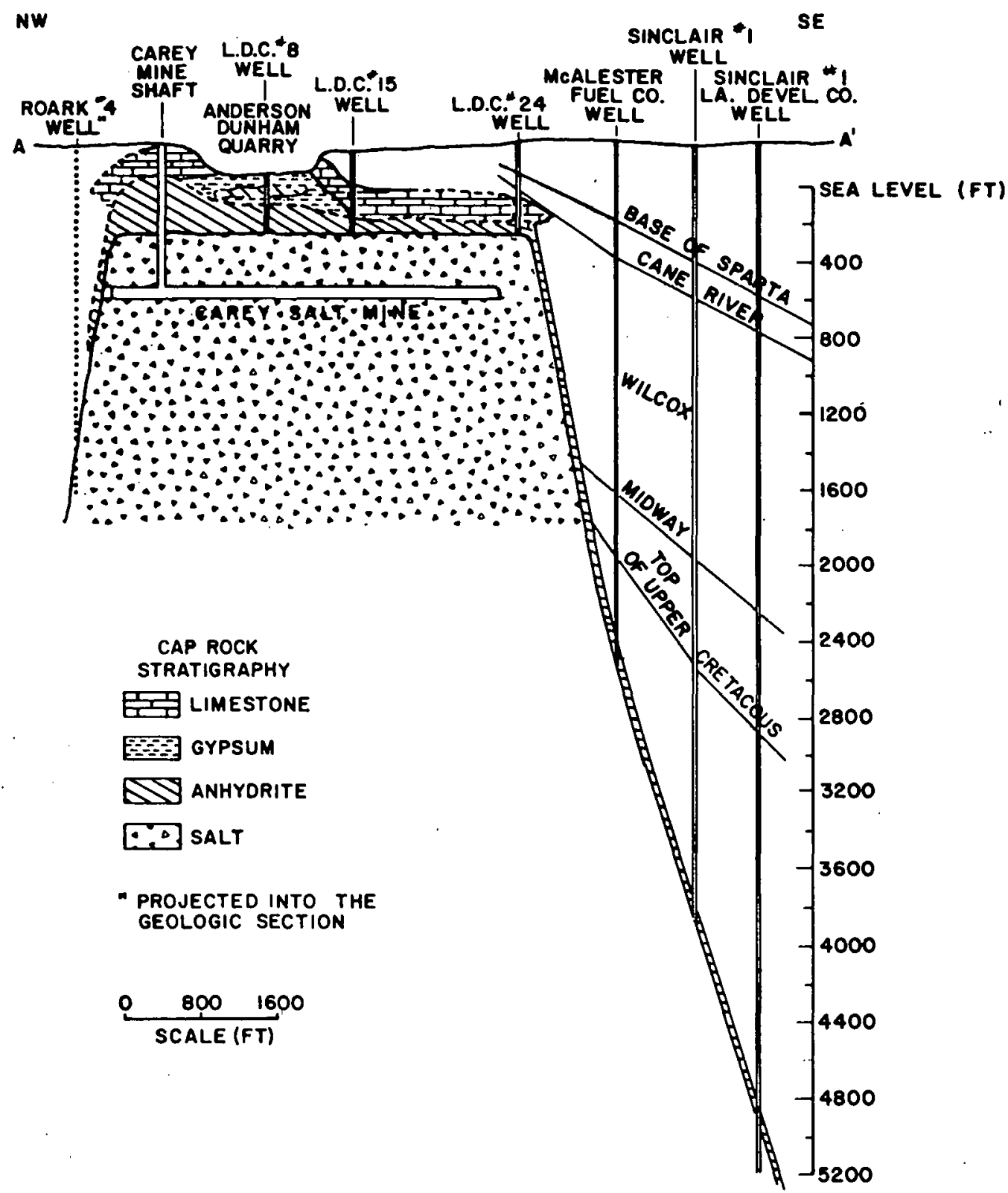

Figure 3.6.2. Section of Winnfield Salt Dome, Winn Parish, Louisiana (After Hăy and others, 1962; Section Modified After Relrhis, 1960). 


\section{History}

The Winnfield salt dome was studied as early as 1869, mainly because of its unusual outcrop of caprock. $0 i l$ and gas exploration commenced between 1914 and 1921. Salt was discovered in 1920 by the Cady Petroleum Company Southern Mineral Company Lyons No. 1. Salt has been mined continuously since 1932, when the Carey Salt Company of Hutchinson, Kansas, began operations. Quarry operations above the dome began in 1936 and are still producing gypsum and anhydrite today. More oil and gas exploration was conducted in the 1950's. and in 1959 the Atomic. Fneray rnmmissinn started its Project Cowboy experiments in the mine. (See Belchic, 1960, p. 29-30.) These tests were a series of chemical explosions detnnated in the ronrk salt in a portion of the Carey salt mine (Short, 1968, p. 632).

\section{Mine Flooding}

The top of the Winnfield salt is immediately overlain with anhydrite. Individual unconsolidated grains of anhydrite sand have been found in a number of wells. These particles are probably due to solutioning of the salt. (See Belchic, 1960, p. 34.)

Ldrye, waler-fllled sulullun cavitles were discovered at the anhydritesalt contact. The water in these cavities may have originated in shallow freshwater sands pierced by the salt stock. A solution cavity at the anhydrite-salt contact was discovered in a well during the Project Cowboy tests. The subsea depth of this cavity was 257 feet. The pressure of the fluid in this cavity was approximately $130 \mathrm{psi}$, as indicated by the presence of water standing in the well bore 45 feet above sea level. Wells drilled through this contact revealed carbon dioxide gas in association with the water and small amounts of inflammable gas, possibly hydrngen sulfide. (See Belchic, 1960, p. 34.)

In 1937, one of the two-inch pipes initially used in the installation of the mine shaft lining to bleed of water began to flow slightly. When a temporary plug was removed from the pipe, a violent burst of gas blew it out, followed by a gush of water and gas, which brought with it anhydrite sand. The water continued to flow at a very high rate, but the gas and sand lessened. Tests showed that the water contained ferrous iron, iron oxide, calcium, and sulfates. The satured brine which first flowed from 
the pipe soon became almost fresh. (See Belchic, 1960, p. 34-35.)

The rapid flow of water is credited for washing the anhydrite sand down into the mine (Belchic, i960, p. 35). This sand probably originated in the cavities above the salt.

The flow of water exceeded a withdrawal rate of 13,000 gallons per hour and the mine was partially flooded. Twenty-two carloads of cement were required to seal off this water flow. Some of the cement was later found in the quarry at a distance of 1100 feet away and 300 feet higher. This is evidence of the continuity of the cavities and their intercommunication with faulting and minor fracturing in the cap rock. (See Belchic, 1960, p. 35.)

Mining was resumed two weeks after the pipe had been sealed and the mine drained. After this initial flooding, only small amounts of water had accumulated near the shaft in a mine sump. This water was attributed to the condensation of moisture from the air pumped into the mine. (See Belchic, 1960, p. 35.)

The quarry operating in the anhydrite caprock of Winnfield dome has a history of water problems. As the size of the quarry increased, small creeks had to be diverted and damed. In 1976, water was being removed from the quarry at a rate of approximately 600 gallons per minute (Martinez and others, 1976, p. 318).

In November, 1965, it was observed that the rate of nomal slow water seepage into the mine was gradually increasing. Investigation in the mine revealed the source to be the bottom corner of a room at a location suspected to be a close approach to the side-edge of the dome. Emergency efforts by pressure grouting over the next few days failed to control this rapidly incrcasing inflow. When the seepage hecame a four-inch-diameter jet of water shooting across the width of the room, the mine was abandoned. Within two days, the mine was completely filled with water and remains so to this day (Martinez and others, 1976, p. 318).

Although there was no local caving or sinkhole formation over the mine at the time of flooding, there was minor ground cracking and other evidence suggesting a general vertical subsidence of the caprock of up to 5 inches (Martinez and others, 1976, p. 319). Perhaps more significantly, there was a very large perturbation of the groundwater system as evidenced by the fact that the seepage into the surface quarry ceased and no pumping was 
necessary for a period of two and one-half years (Martinez and others, 1976, p. 319-320).

Based on these observations, the flooding of the mine appears to be directly related to the close approach of the excavation to the edge of the dome. Slow in-seepage of water from the surrounding caprock, possibly through blast damage on structural fractures slowly enlarged the seepage path by dissolution (and perhaps mechanical erosion) until the inflow rate became very rapid. The water contained in the cavernous and highly permeable caprock then quickly (2 days) and completely drained into the mine. The slight surface subsidence is almost certainly due to minor collapse of some of the caprock porosity upon draining. 


\section{STABILITY PROBLEMS OF MINING CAVITIES IN BEDDED SALT}

\subsection{Subsidence at Grosse Ile, Michigan}

Introduction

In early 19:1, two sinkholes formed rapidly on the Grosse Ile brine field of BASF Wyandotte Corporation. The collapse features were the result of solution min ing over a period of about 30 years. Surveys of surface settlements had seen conducted for 18 years prior to the developinent of the sinkholes. Two separatc rcports detailing the events relating to the subsidence were puslished by the Solution Mining Research Institute. The environmental effects of the subsidence were reported by Landes and Piper (1972), and the nechanisms of the collapse were discussed by Nieto-Pescetto and Hendron (1977). The following sections are based on these two reports.

\section{History}

Solution mining operations for the production of salt began in the Detroit area in 1895. Limited brine production on the perimeter of the Grosse Ile brine field at the Point Hennepin location began in 1941. Prior to this, brine was produced on the mainland. Before salt wells were developed on the rest of Point Hennepin, this area was used for the disposal of tailings from the manufacture of soda ash. These tailings were piped to the island, ponded, and allowed to settle. During the period 1948 to 1950, when disposal was stopped, the tailings were accumulated to about 30 feet above the natural land surface. The main constituents of these tailings are calcium carbonate, calcium sulfate, and calcium hydroxide. Silica and other insoluble impurities from the original limestone raw material used in the production of soda ash are also present. Most of the well operations of BASF Wyandotte Corporation are located on top of the tailing plateau. (See Landes and Piper, 1972, p. 6-7, 9.)

Beginning in 1943, brine wells were operated on Grosse lle by the conventional single-well method of injecting water down a tube and forcing brine up through the annulus between the tubing and the well-casing. The single-well cavities fomed by this procedure later coalesced into two major galleries, labeled North and Central in Figure 4.1.1, and several minor galleries. (See Landes and Piper, 1972, p. 19.) Table 4.1.1 gives 


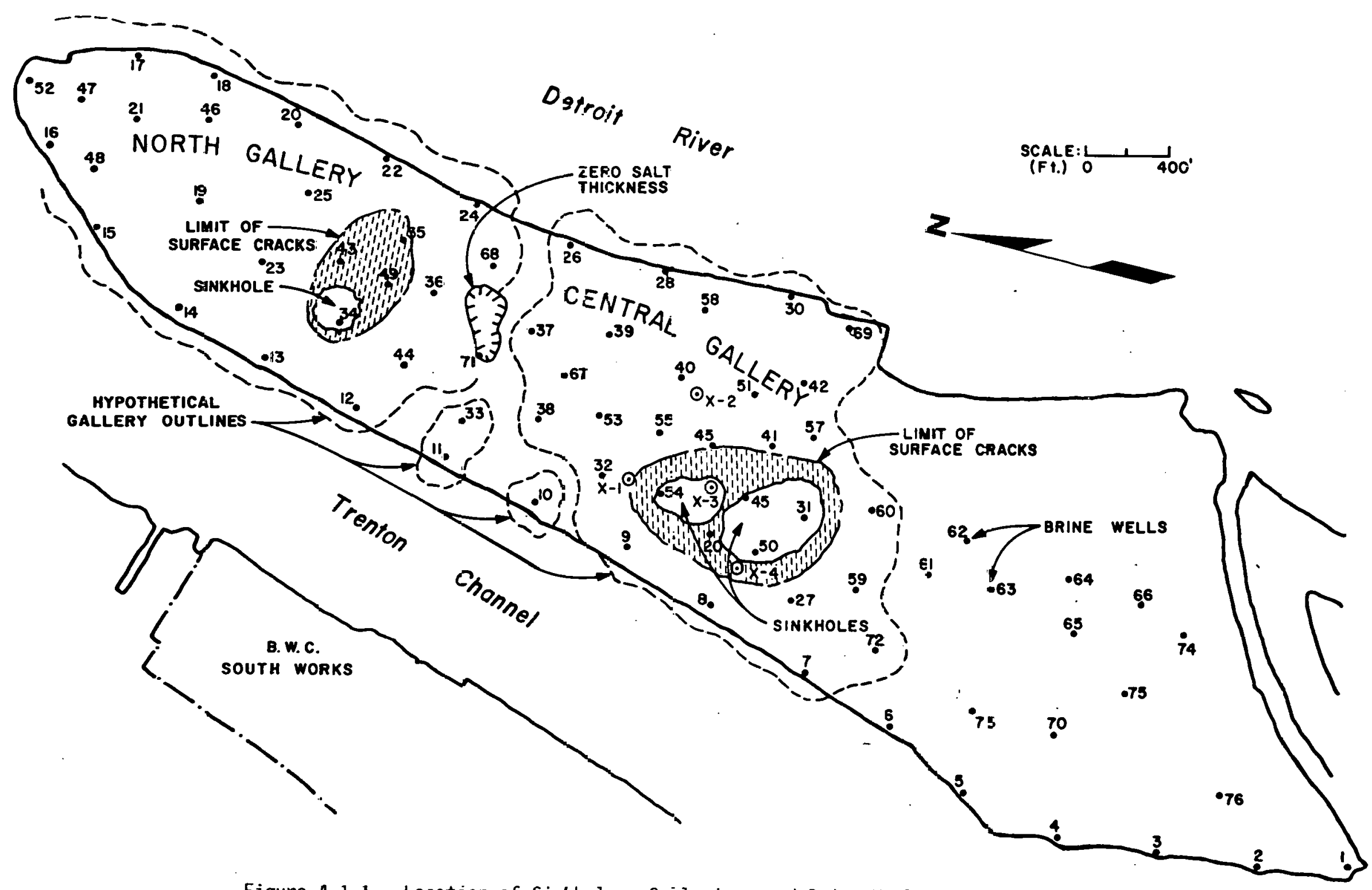

Figure 4.1.1. Location of Sinkho?es, Ga!leries, and Brine Wells at Grosse Ile, Michigan (After Landes and Piper, 972). 
TABLE 4.1.1. Production History of Grosse Ile Brine Field

(After Nieto-Pescetto and Hendron, 1977, p. 12).

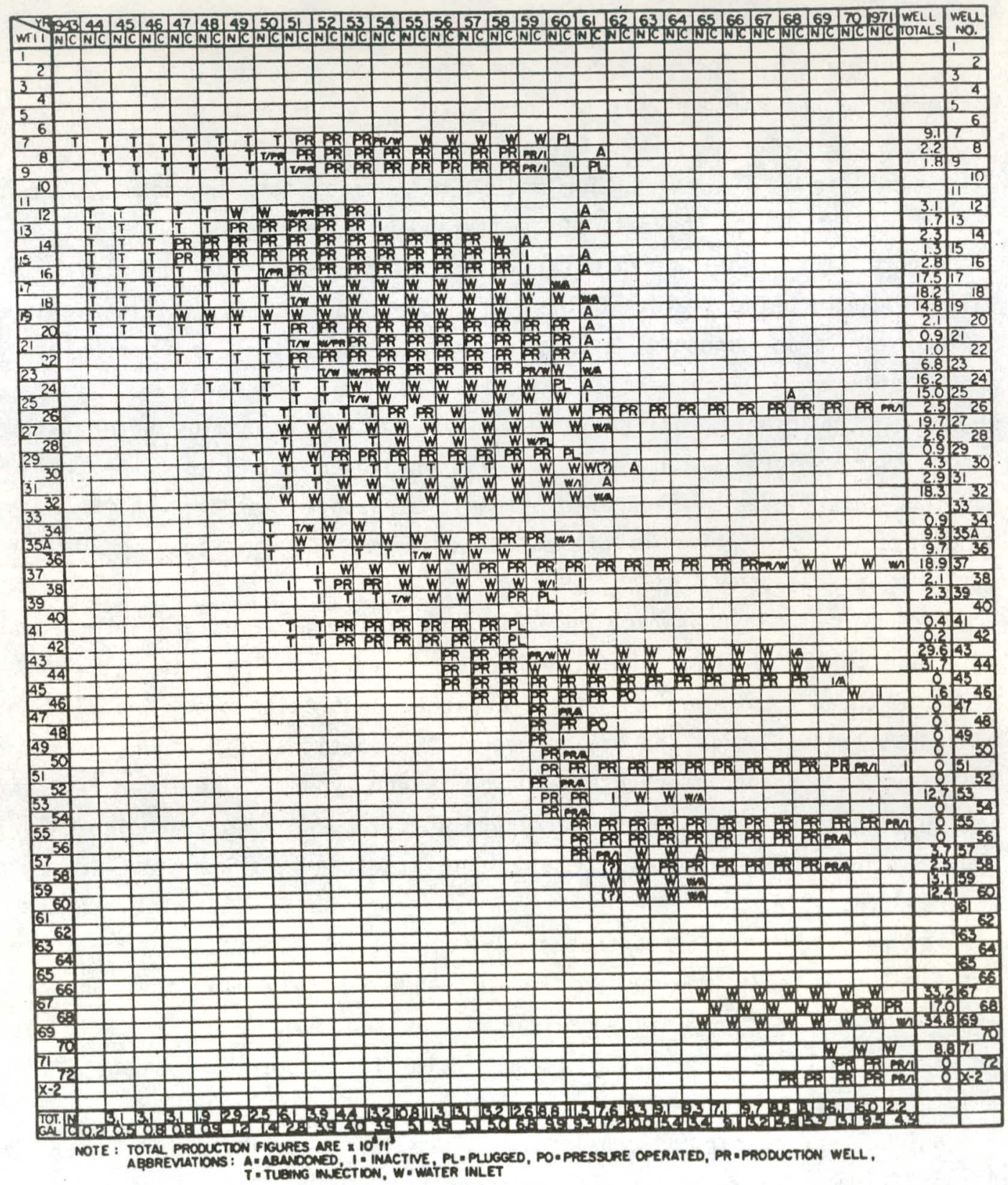


the production history of 73 wells shown in figure 4.1.1. These data, coupled with assumptions regarding initial cavity shape, can be used to estimate an effective extraction ratio in the galleries.

\section{Location and Stratigraphy}

The brine fields of the BASF Wyandotte Corporation are located on Point Hennepin, on the northern tip of Grosse Ile. The island is in the Detroit River, adjacent to the city of Wyandotte, a suburb of Detroit, Michigan. Point Hennepin is $11 / 4$ miles long and $1 / 4$ mile wide, covering about 200 acres, and is separated from the rest of the island by a lagoon.

Figure 4.1 .2 shows a typical core log of the sediments underlying the Point Hennepin brine field. Below the 30 feet of man-made tailings on the surface of Point Hennepin is about 60 feet of glacial drift consisting mostly, of clay. Detroit River dolomite, having a thickness of 150 feet, underlies the glacial drift. This layer of rock contains water-filled cracks and joints which have a high hydrogen sulfide content. A 150-foot-thick layer of saturated Sylvania sandstone lies beneath the dolomite layer. Cementation is present in different degrees from moderate to tight. (See Landes and Piper, 1972, p. 9.)

The dolomite layers which underlie the sandstone layer are interbedded with anhydrite, gypsum, shale, and minor chert. Proceeding down the sequence there is 70 feet of Bois Blanc cherty dolomite sverlying 370 feet. of Bass Island dolomite and Salina evaporites (designated $G$ and $F$ in Figure 4.1.2) which contain interbeds of anhydrite and gypsum. The 1 ower 270 feet (designated $E$ and $C$ in Figure 4.1.2) are argillaceous. Core samples reveal that the dolomite layers are massive but fractured. (See Nieto-Pescetto and Hendron, 1977, p. 7.)

The salt beds are first encountered at a depth of about 810 feet. The principal salt bed, however, is located approximately 1150 feet deep and is 200 feet thick. Interbeds up to several feet thick of dolomitc, anhydrite, and salt-impregnated, shaly dolomite compose 20 percent of the thickness of the units.

A local structural and erosional feature is responsible for causing the B salt (Figure 4.1.2) to be discontinuous beneath the Point Hennepin brine field between the North and Central galleries. Figure 4.1.1 shows the location of the "pinchout", a zone of nearly zero salt thickness, roughly 
WYANDOTTE CORE HOLE NO.2; NORTHERN GROSSE ILE

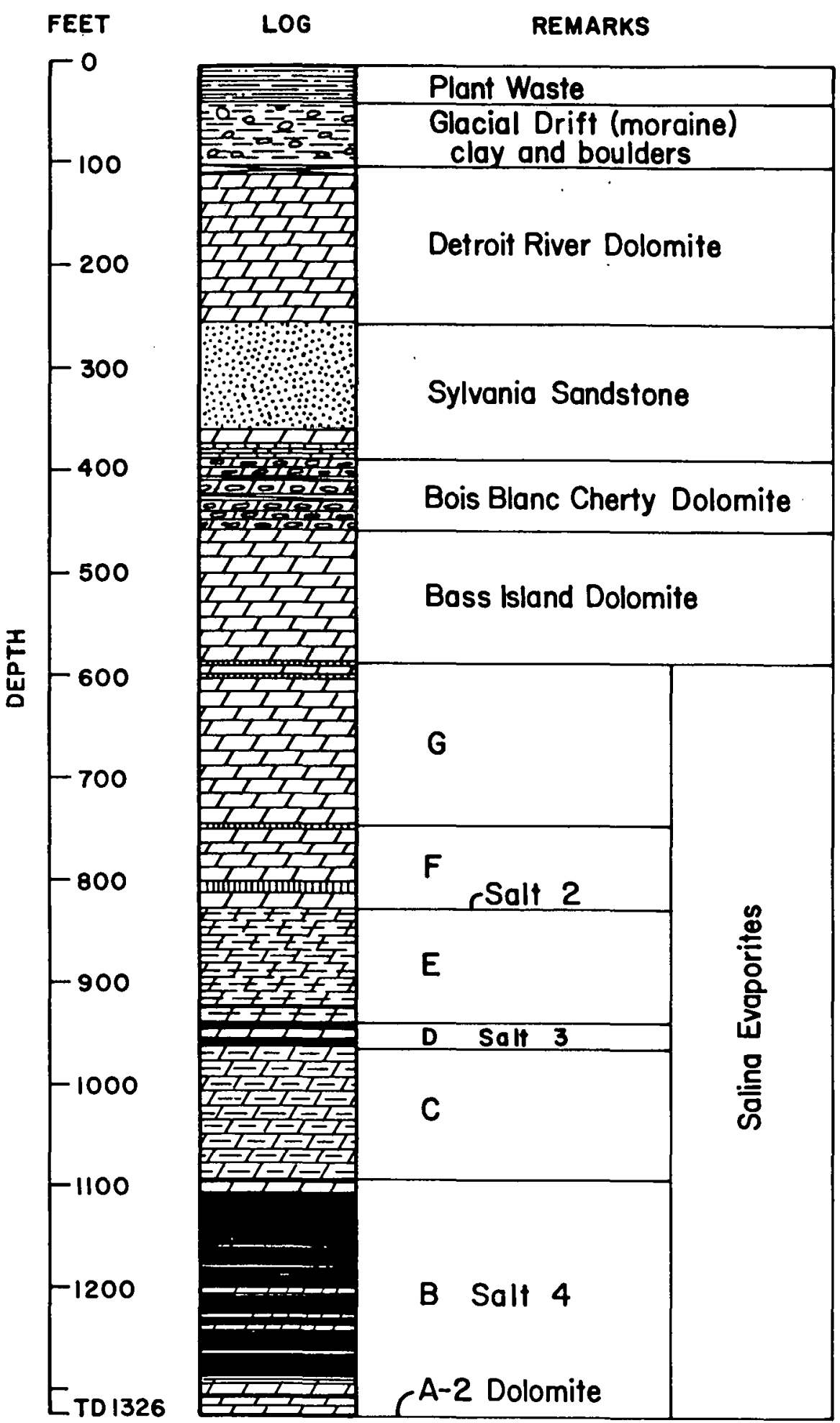

Figure 4.1.2. Typical Core of Point Hennepin Brine Field, Grosse Ile, Michigan (After Landes and Piper, 1972). 
along a line which connects wells $11,33,71$ and 68. Jaron (1966, p. 425) describes this feature as a solution collapse structure which occurred when the $B$ and $C$ units (Figure 4.1.2) were deposited. Apparently the $B$ unit of salt was dissolutioned by water soon after deposition. The resulting cavity was replaced by the bulking of collapsed insoluble ledges from the $B$ salt section, roughly 50 feet of the overlying unit $C$ roof rock, and by the thickening of the remainder of unit $C$ as it was deposited. This solution and collapse sequence during Salina time dates the discontinuity in the salt structure prior to subsequent deposition of the undisturbed overlying beds. This solution feature, which physically separates the North and Central galleries (Figure 4.1.1), may be an important factor contributing to the Grosse Ile sinkholes.'

\section{Subsidence Activity}

Beginning in 1954, elevations were recorded at reference points on the Point Hennepin brine field. Downwarping up to one-quarter inch per year was considered acceptable in this area. Total subsidence measurements of several feet over the entire area were also acceptable as long as the downwarping did not cause tension breaks in brine pipe lines or other damage. It was estimated that the subsidence in the brine field would be limited to only several feet, and repairs to equipment were made accordingly. (See Landes and Piper, 1972, p. 21, 27.) Figure 4.1.3 shows subsidence profiles along a section taken roughly through the center of bnth sinkhnles. This figure also shows the extent of the two sinkholes, limits of surface cracking, thickness of the salt, and the location of wells along this section. The last profile plotted shows the displacement in December, 1970, only one month before the sinkhole formed in the North gallery and four months before the sinkhole formed in the Central gallery.

Northern Gallery Sinkhole

In October. 1969, when abandnned well No. 49 was about to be plugged, it was discovered that the casing had parted at 260, 370, and 700 feet. Quarter-inch wide cracks were observed in the roadway near well 49 in November, 1969. No vertical displacement was indicated by these tcnsile cracks and they were arranged circumferentially to the subsequent depression. 


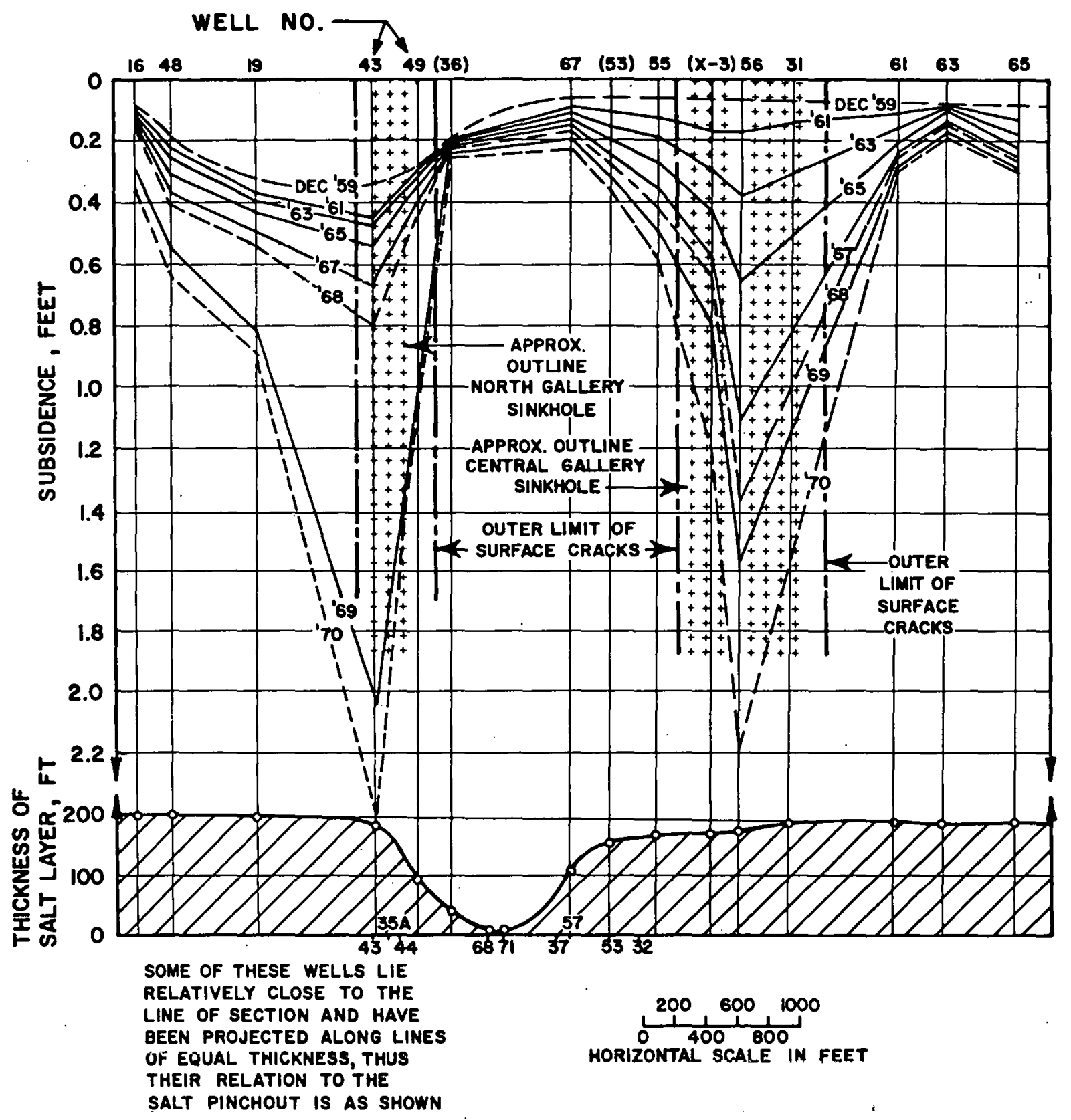

4.1.3. Subsidence Profiles Aicng a Section Through both Sinkholes at Grosse Ile, Michigan (After Neito-Pescetto and Hendron, 1977). 
From March to October, 1970, several breaks and leaks in pipcs that serviced the North gallery were found and repaired. On November 10, 1970, cracks several inches wide in the surface of a road near well 49 were observed. There was also an increase in injection pressure in well 71 and observation well 44 showed a rise in its static fluid level of about 20 feet. At well 48, water containing sulfur flowed from the casing of a surface pipe. At this time a smooth, basin-shaped depression formed south and east of well 43, measuring 100 feet in diameter and approximately 2.5 feet deep. By November 12, 1970, the settlement around well 43 totaled 6 feet 1 inch since the September reading. Water and brine mains continued to break as the sinkhole continued to widen and deepen. On January 27, 1971, water began filling the sinkhole, equal to the river level. A sulfurous odor was detected. On April 22, 1971, the steep scarps of the hole were excavated in an attempt to make them less of a safety hazard. The depth at this time was estimated to be 100 feet. Other than minor additional settlement, the sinkhole appeared to have stabilized by May, 1971. (See Landes and Piper, 1972, p. 27-34.)

\section{Central Gallery Sinkholes}

III May, 1970, Lhe wells within the lentral gallery were largely retired, in advance of retirement of this entire gallery. The formation of the sinkhole was not preceded by cracking and downwarping as noted before the North gallery sinkhole formed. The only indiration at this time that anything unusual was happening was an influx of water containing sulfur into wells 51, 55, and $X-2$, noted when the feed water was out of balance with brine production. The area was inspected on a daily basis, and other than the normal subsidence measured from the leveling of reference points, no unusual subsidence was observed. (See Landes and Piper, 1972, p. 35.)

A developing sinkhole was discovered southwest of well 29 at 7:00 p.m. on April 28, 1971. The rapid ground subsidence was marked by the flow of sulfur water from wells 9, 29, 41, and 42. On April 29, 1971, the sinkhole had developed to about 200 feet in diameter with a fluid level about 15 feet below the original road grade previously crossing the sinkhole area. By late afternoon on the same day, the hole was an ellipse about $400 \times 150$ feet, with the major axis running northwest to southeast. Collapse continued through May 22, 1971, when several feet of additional settlement was 
noted near well X-3. Three days later on May 25, 1971, a satellite sinkhole, approximately 200 feet in diameter, developed in the area of wells 29, 54, and $X-3$. This sinkhole continued to develop until June 1 , 1971. After this date, the two sinkholes appeared stable, with some selffilling by collapsed material from the side walls. (See Landes and Piper, 1972, p. 35-36.) A typical time-versus-settlement curve is shown in Figure 4.1.4. This curve shows that subsidence increased rapidly in the two years prior to sinkhole formation.

Because of the dangerous access to the North gallery and satellite sinkholes, soundings were possible at the Central gallery sinkhole only. These soundings indicated that the Central gallery had a flat bottom and was 100 to 120 feet deep below the water level.

Mechanism

The mechanism of the Grosse Ile sinkholes is postulated by Nieto-Pescetto and Mendron (1977, p. 38-39):

"Removal of roof support by the coalescence of conventional cavities was evidenced early in the development of the field. For the North gallery, a bowl of subsidence had al ready developed for the period of 1954 to 1959... Th is removal of roof support induced roof sagging and concentration of vertical stresses around the periphery of the gallery. This in turn accelerated the creep of the salt forming the walls of the gallery and caused further subsidence of the roof rock. Pillars that were left inside the gallery probably tapered up and had small areas of contact with the roof rock; these pillars also yielded by creep to the weight of the overlying rock. The sagging roof rock reacted elastically at very small strains, but as sagging continued to develop, the roof beds developed concentric tensile cracks or existing ones opened up. For each bed these cracks propagated downward from the top of the beds around the periphery of the gallery and upwards from the bottom of the bed in the center of the gallery. The tensile strains at the bottom of the bed in the center of the gallery were greater than the corresponding strains at the top of the beds around the periphery. Thus, fracturing in the center was probably more intense and the fractures were more closely spaced.

As production, removal of support, and sagging proceeded, the fracturing described above propagated upwards. These concentric vertical fractures probably accomodated most of the inelastic vertical displacements detected at the surface. Thus even though genetically they were tensile fractures, they operated as vertical shears to accommodate the large strains induced by salt creep within the gallery. This resulted in a surface bowl of subsidence 


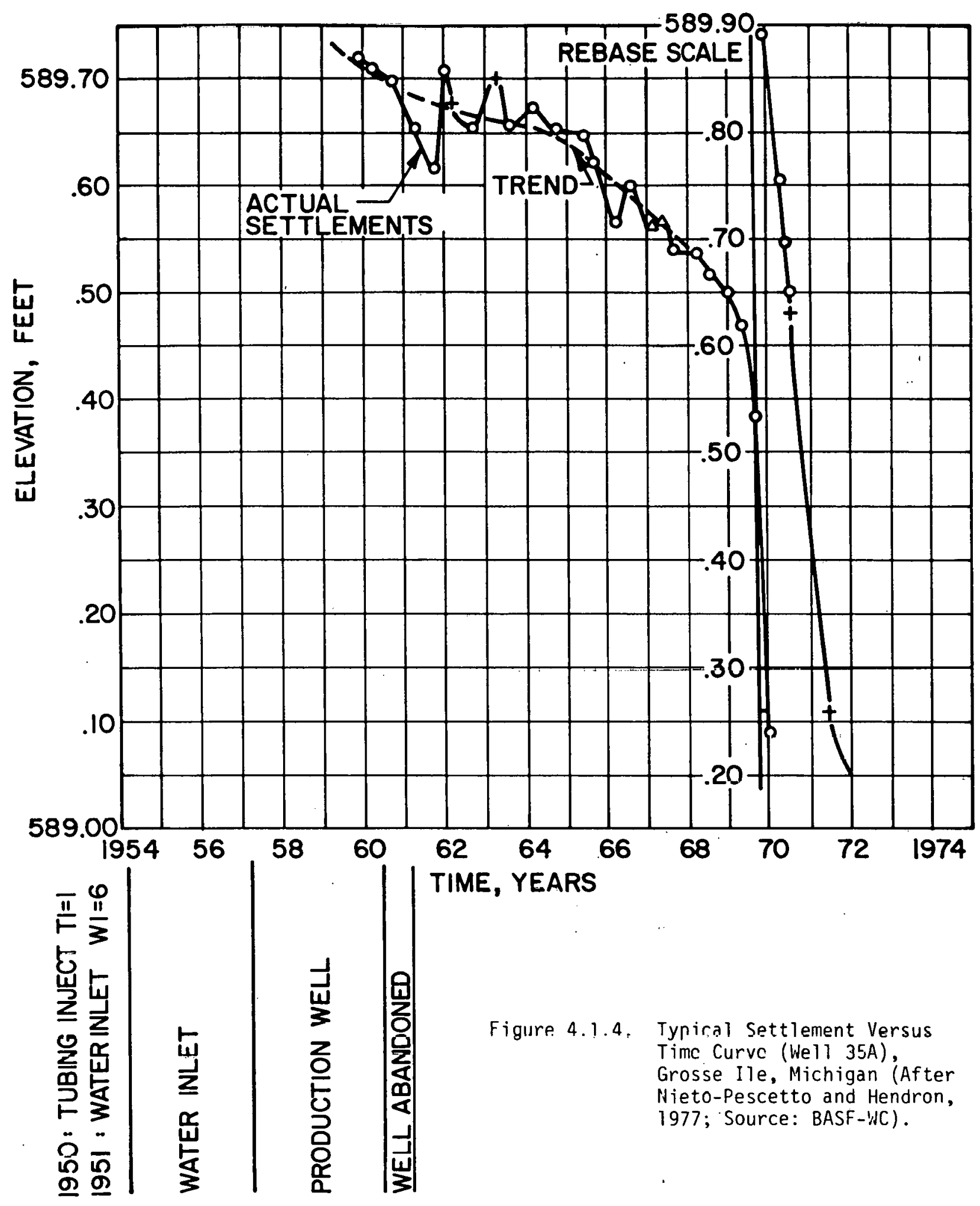


of approximately the same size as the area of heavy production. Since the initial undermining activity had effectively removed a great part of the salt under the roof rock and this rock was fairly well fractured, stoping could easily begin. This could happen more easily in the center of the gallery where fracturing was more intense. At this point it should be mentioned that removal of salt under the roof of a gallery not only allows subsidence but it also permits the loosening of the rock. In this respect, salt against the roof behaves similarly as rock bolting; it prevents the blocks of the roof rock from losing interlocking along rough fractures."

More than one cause probably contributed to the sinkhole formation at Grosse Ile. In the first phases of salt solutioning, in which single cavity wells were used, a large amount of roof support was removed relative to the volume of salt which was extracted. This occurs because the highest rate of salt extraction is at the top of the cavity immediately under the roof. Later, the technique of connecting the wells by undercutting was meant to alleviate this problem by forcing lateral dissolution, but these measures were implemented after some roof support had already been lost.

A salt pinchout is believed to have contributed to the formation of large cavities by causing concentrated extraction on either side of its axis. The extensive use of inlet wells, which accounted for almost 45 percent of the total production in the North and Central galleries, was responsible for the concentrated extraction in the area adjacent to the pinchout. Bowls of subsidence formed on both sides of the pinchout, and when the settlement in the center of the bowls reached about" 2 feet, sinkholes formed. The relocation of inlet wells in 1961 and 1968 in the Central and North galleries, respectively, did reduce subsidence rates but did not halt the eventual formation of the sinkholes. (See Nieto-Pescetto and Hendron, 1977, p. 48.) 


\subsection{Windsor, Canada, 1954 Subsidence}

\section{Introduction}

On February 19, 1954, a rapid subsidence occurred in the Sandwich brine field area on land owned by Canadian Salt Company and Canadian Industries Ltd. in Windsor, Ontario, Canada. Salt was being produced in this area by conventional gallery solution mining techniques which involve pumping fresh water into the salt beds through input wells and removing the brine through production wells (Landes and Piper, 1972, p. 17). This production method results in a merging of the individual salt cavities into a common gallery. Inadequate roof support above the qallery prnhahly caused the rcsulting localized subsidence.

\section{History of Brine Extraction}

Brine wells were first drilled in the Sandwich brine field in 1902. Between 1922 and 1953, 25 active wells were in production. These wells were drilled to the base of the Lower Salt (Figure 4.2.1), about 1600 feet in depth. Most of the wells were operated as water-forcing wells, which eventually coalesced into a common gallery. The gallery lost its pressuretight properties in about 1934, after which time brine was recovered by using deep well pumps. (See R. Terzaghi, 1970, p. 300.)

All wells drilled after 1918 were designed to produce brine froll the zUU-foot-thick layer of Lower Salt. Rockfalls, caused by the removal of supporting layers of salt from this region, indicate that this layer was the major source of brine produced. Data on design, construction, and operation of the wells, as well as faulty well sasings and inadcquate packers indicate that a large quantity of brine was removed from the Upper and Middle Salt layers, too. (See R. Terzaghi, 1970, p. 300.)

According to Bays (R. Terzaghi, 1970, p. 300), the amount of brine extracted was considerably less than the amount of fresh water injected. This accounts for Bays' estimate of 150 million cubic feet of salt having been removed from the deposits, while total production of brine was only about 71 million cubic feet.

There is little information concerning the size and shape of the individual cavities or the final coalesced cavity in the reports. Wells 5, 6 , 7 , and 9, located in a zone extending from the north side of the brine 


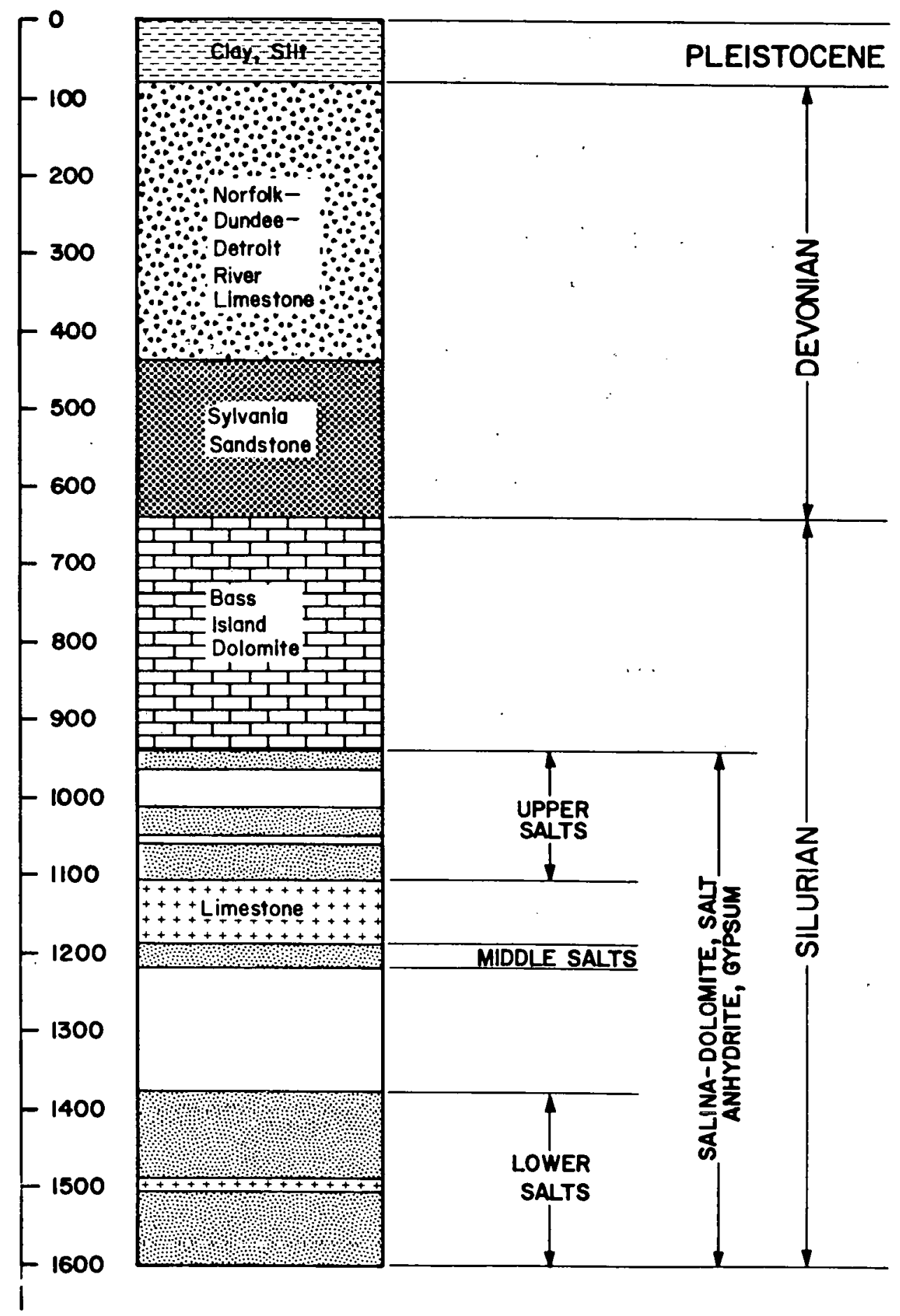

Figure 4.2.1. Typical Geologic Section Underlying the Windsor Brine Field (After R. Terzaghi, 1970). 
field to the south side are perhaps the location of the greatest solutioning. Surface subsidence was greatest in the southern part of this zone. (See R. Terzaghi, 1970, p. 300.)

\section{Stratigraphy}

A typical section of the Sandwhich brine field is shown in Figure 4.2.1. Unconsolidated Pleistocene deposits, composed primarily of stiff silt and clay, lie at the surface in the brine field. The clay which underlies the subsidence area is between 91 and 99 feet thick and overlies a few feet of sand or gravel. Drilling operations in the Norfolk or Dundee-Detroit Limestone Formation which underlies the Pleistocene sediments have encountered large amounts of water and mud. This suggest that the limestone is extensively jointed and fractured (Bays in R. Terzaghi, 1970, p. 299).

Beneath the Norfolk Formation is the Sylvania Sandstone Formation. Bays (R. Terzaghi, 1970, p. 299) reports that the sandstone is usually found in two benches, separated by gray and brown limestone. Some of the beds are cemented with carbonate or silica and others are loose.

The uppermost 200 feet of the Bass. Island carbonate strata that underlies the Sylvania Formation is reported by K. Terzaghi in R. Terzaghi (1970, p. 299) to have widely-spaced joints with strong bonds between bedding planes, yielding a competent rock able to bridge cavities spanning several hundred feet without failure.

Three distinct layers of evaporites lie within the Salina Formation of Silurian age. The uppermost evaporite bed is encountered at 975 to 1000 feet. As illustrated in Figure 4.2.1, the three salt beds are separated by varying thicknesses of strata. The upper salts are divided by a carbonate layer. At a depth of around 1100 feet, a layer of limestone rock separates the Upper and Middle salt layers. Well drillings reveal that the Middle salt consists of a thin, discontinuous layer of salt between 1200 and 1250 fcct. (Sce R. Terzaghi, 1970, p. 299-300.)

Cavities in the salt, up to 20 feet in height, were discovered when wells were drilled in both the Upper and Lower salts. Some, if not all of these cavities may have occurred naturally.

At depths of about 1400 and 1600 feet, two beds of lower salt are found. The total thickness of this salt is about 200 feet, and the two 
layers are separated by a few feet of limestone. (See R. Terzaghi, 1970, p. 300.)

There is little indication of deformation in the area. Dips average 60 to 70 feet per mile, rarely exceeding 100 feet per mile (Bays, 1954 in R. Terzaghi, 1970, p. 300).

\section{Events Leading to Major Subsidence}

Settlement in the brine field area had been recorded since october, 1948. Cracks in a number of plant buildings had become apparent, and plant officials started to investigate the cause of the cracking. At this time about 80 reference marks were made on buildings in the plant. More points were established in 1949, 1951, and 1953. The buildings on which these marks were placed rest on shallow foundations (K. Terzaghi, 1954, p. 4). From Peck's 1954 evaluation of the settlement data, it is shown that the ground settled up to 1.5, inches between October, 1948, and 0ctober, 1950, in an irregular pattern. Between October, 1950, and October, 1951, subsidence slightly greater than 2.5 inches per year was recorded north of the Liquid Chlorine Plant (Figure 4.2.2). An increase in settlement of 3 inches was noted east of the Hydrogen Tank (located north" of the Liquid Chlorine Plant) between October, 1951, and October, 1952. Contour lines from Peck's (1954, Figure 4) report show that the rate of subsidence started to decrease from the edge of the sinkhole towards its center at this time.

Subsidence at the Liquid Chlorine Plant was 9 inches from October, 1952, to October, 1953. A bowl-shaped depression with a: radius greater than 1000 feet could be discerned. (See K. Terzaghi, 1954, p. 5.)

Subsidence prior to the recorded observations of 1949 were estimated by Peck (1954, p. 6-7) from differential level surveys. Differential settlements between buildings on the plant site show that the maximum subsidence in the plant area did not exceed 3 feet before the major subsidence.

Sinkhole Development

Belween 8:00 and 9:00 a.11. un Friday, February 19, 1954, Lhe rirsl indications of the imminent ground subsidence were detected by plant employees. Sounds and vibrations resembling the bumping of rail cars, the rumbling of a small earthquake, blasting, and cracking were heard and felt, 


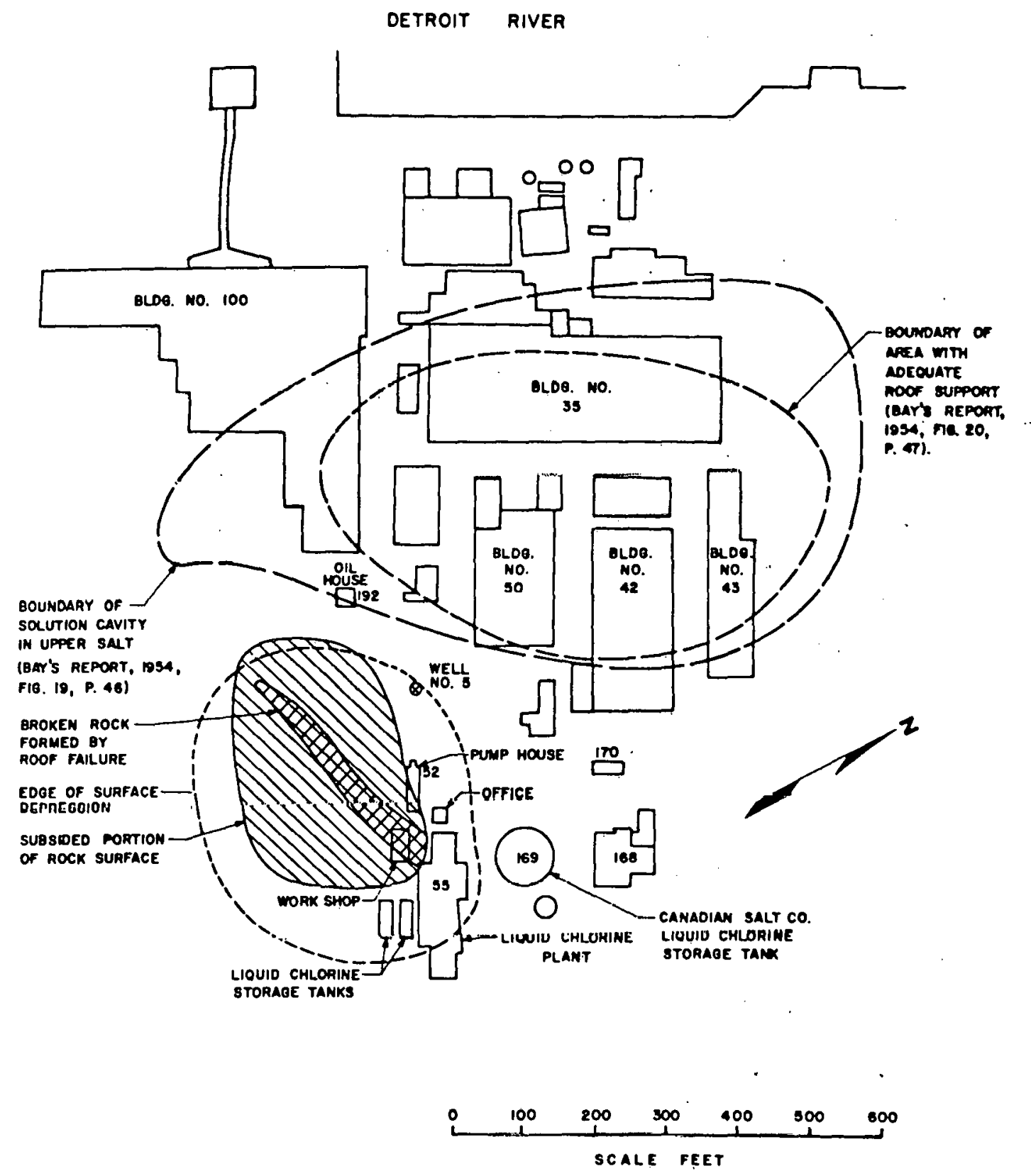

Figure 4.2.2 Windsor Brine Field and Operations Buildings (After Peck 1954). 
apparently originating below the offices of the Canadian Salt Company, Ltd. The noises became louder and the vibrations were severe shortly after 9:00 a.m., and were noted by employees of Canadian Industries, Ltd. (adjacent to the Canadian Salt plant) as well. 'These occurrences were, at the time, attributed to blasting or the switching of locomotives in the yard. (See Peck, 1954, Appendix I.)

At 9:30 a.m., the first physical signs of subsidence could be seen in the area shown in Figure 4.2.2. "An air line broke at its entrance into the liquid chlorine compressor room. By 10:30 a.m., underground water lines had broken beside the bulk storage building. The new subsidence was now clearly visible in an area between the liquid chlorine storage tanks to a point approximately 75 feet towards the Detroit River. A small crack, approximately one inch wide, opened in the ground near the railroad tracks running adjacent to the Canadian Salt Co. storage tanks. Topsoil began falling into the crack. Water from an adjacent swamp was beginning to fill an approximately 18-inch depression, which had formed in a Canadian Industries road. About noon a ruptured brine line and an underground water main contributed to the flooding. A "gusher" five feet in length and lasting five minutes appeared from a fissure which formed near abandoned well No. 5. More gushers and sprays occurred as the ground subsided more rapidly. A rapid subsidence took place around $1: 45$ p.m., around the north rim of the depression, amounting to approximately 3 feet. A.gusher which formed a 4-foot-high, 75-foot-long wall of water accompanied this subsidence. Individual jets of water shot upwards, lasting two to three minutes. The water from these jets was black and had a sulfurous odor. This was the last major occurrence, and by 2:30 to 3:00 p.m., the subsidence appeared stable. The resulting bowl-shaped depression had a radius of roughly 1000 feet. The size of the elliptical lake formed in the center of the depression was 350 feet wide and 450 feet long. The bottom of the lake was surveyed one week after its formation and was found to be 28 feet below the original ground surface. This point of maximum..depth is located about 60 feet from the north shore of the lake. (See Peck, 1954, Appendix I.) Some additional movement was detected until March 23. This movement was local and could be attributed to the mobile clay subsoil adjusting to its new position. During this time the lake bottom rose 5.5 feet, and other portions subsided up to 2.5 feet. (See K. Terzaghi, 1954, p. 6.) 


\section{Subsidence Due to Filling of Sinkhole}

The Canadian Salt Company began filling the sinkhole on March 31, 1954, with pit run sand and gravel. This backfilling activity caused additional settlement of about 2.5 feet, due to the weight of the fill. (See Peck, 1954, p. 9.)

It was necessary to pump water out of the sinkhole to obtain the proper density of the fill material. Subsequent water seeping into the hole came from the sides and not from the bottom. No sulfur. was present in the water. The removal of water caused tension cracks to widen bcyond the edge of the crater and the area adjacent to the shoreline subsided. This movement was a result of a shift in equilibrium of the underlying $c l$ ay beneath the slopes of the bowl of subsidence. (See Peck, 1954, p. 9.)

\section{Indication of Subsidence on Buildings}

Buildings in the vicinity of the sinkhole were surveyed after the February 19, 1954 sinkhole formed to determine subsidence. All buildings adjacent to the sinkhole leaned in its direction. Cracks were discovered in the walls of the buildings located near the sinkhole and appeared to be mostiy random in nature. Most of the cracks appeared to have originated at the foundations and extend upwards towards the roofs. Building 100 (Figure 4.2.2) exhibited crack patterns indicating a consistent set of deformations from stretrhing in the east-wect dircction. Total widlh ir lhese cracks was 3 inches. (See Peck, 1954, Figures 18-20.) The east wall of Building 100 tilted 15.5 inches over a length of 270 feet. $K$. Terzaghi concludes that the cracks must have begun to open up several years beforo the major subsidence (K. Terzaghi, 1954, p. 7-8).

\section{Mechanics of Subsidence}

Two theories explaining the events that led to the formation of the sinkhole are discussed by Karl Terzaghi (1954) and Ruth Terzaghi (1970), based on the work of Carl Bays. The first is the theory of localized rock subsidence in which the surface of the bedrock surrounding the sinkhole area remained stationary and the bedrock dred within the sinkhole area settled. The second theory is of general subsidence, in which the ground surface subsidence was approximately equal to the subsidence of the rock surface. 


\section{Localized Subsidence}

The theory of localized subsidence, as explained by K. Terzaghi (1954, p. 11-13), is based on the following sequence of events. Before 1951, the intact rock below the subsided area stoped and decreased in thickness from around 900 feet to about 300 or 400 feet over an area of 70,000 square feet. Rock fragments had accumulated on the floor of the solution cavity below the remaining sound, intact rock. The bottom of the cavity was separated from the roof by 20 to $30 \mathrm{feet}$ of water. As the thickness of the intact rock decreased, due to increasing fragmentation, the rock above the center of the cavity began to subside, and the overlying clay began to flow towards the center of the subsidence. K. Terzaghi (1954, p. 13) states that the average downward movement of the intact rock increased from a few feet to almost 15 feet from 1952 to 1953. He further concludes that movement this great would be improbable unless the thickness of the rock had been reduced to less than 200 feet. The tension cracks discovered in the north wall of Building 100 are explained by radial stretching of the stiff crust above the moving clay. Radial compression of the stiff crust may account for the rate of subsidence in the center of the sinkhole being less than at its edges between 1951 and 1952. (See K. Terzaghi, 1954, p. 13-14.)

In 1953, before the sinkhole developed, the radius of the area subsiding increased by 7 or 8 feet. Bending and shear along the edges caused the rock to fail in February, 1954. Fifteen feet of water-filled space between the overlying rock and the rock fragments at the bottom of the cavity accounts for the additional 15 feet of subsidence and the large

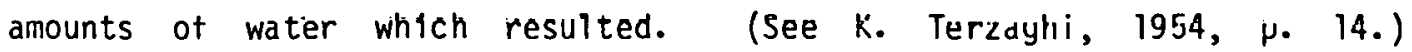

Karl Terzaghi (1954, p. 15) explains the mechanism of localized subsidence as follows:

"As soon as the process of stoping arrived at a depth of several hundred feet below the surface of the bedrock and the rock foundation of the clay stratum started to disintegrate, water under pressure rose through joints in the rock and started to invade the sandy, glacial sediments located between bedrock and clay. Since the permeability of these sediments is very high compared to that of the clay, the hydrostatic pressure was transmitted from the sinkhole area in the radial direction over long distances and the hydrostatic pressure in the pore-water of the sediments reduced the effective pressure exerted by the clay 
on the sediments to a value close to zero. At the instant of the sinkhole formation the continuity of the clay stratum was disrupted by tension cracks and the water under pressure shot out of the ground in the form of jets and of sheets of water, as described by the eye witnesses."

The theory of the flow of clay toward the center of the sinkhole area does not seem to be the correct mechanism to explain the rapid subsidence for two reasons. First, R. Terzaghi (1970, p. 305) reports that the clay is actually of a stiff and immobile character. Second, if the clay had actually flowed before the major subsidence event, it should have continued to flow after the event, because the average gradient around the depression was at least as high after the subsidence as prior to the sinkhnle formation. Therefore, this theory is considered not plausible unless check borings could prove that the amount of clay above the subsidence area had increased by at least five million cubic feet between' 1948 and 1953 ( $K$. Terzaghi, 1954, p. 15).

\section{General Subsidence}

The Windsor brine field subsidence is thought to have a similar mechanism as the 1971 Grosse Ile subsidences. Salt solutioning, whish caused the coalescence of many cavities into one massive cavity, removed much of the roof support above the cavity. The removal of this roof support induced roof sagging and concentrated the vertical stresses around the perimeter of the gallery walls. This roof sagging was first seen as a gradual downwarping of the ground above the brine wells. Further subsidence of the roof rock was caused as the gallery walls began to creep at an accelerated rate as the result of the stress concentration. As the sagging continued, cracking developed downwards in the perimeter of the cavity and upwards from the bottom of the beds in the center of the gallery. The tensile strains at the bottom of the bed in the center of the gallery were greater than those at the top of the beds around the perlimeter, indicating more intense and closely-spaced fracturing in the center. The upward movement of the fracturing and the removal of roof support eventually resulted in sinkhole formation. (See Nieto-Pescetto and Hendron, 1977, p. 38-39.)

The areas thought to have adequate roof support below the brine field are shown in Figure 4.2.2. The subsidence is approximately the same size 
as the area where the most salt was removed.

Although gradual subsidence was noted far in advance of the sinkhole formation, no attempts were made to arrest the subsidence. R. Terzaghi (1970, p. 303) illustrates the deformation of the bedrock from surface subsidence measurements over a number of years in Figure 4.2.3. The illustration is based on profiles through the west part of the sinkhole to the edge of the area where subsidence measurements were made.

Similarities exist between the Grosse Ile and Windsor collapses. The formation of each sinkhole was within well-developed bowls of localized subsidence. Both the subsidence bowls and the subsequent sinkholes had approximately equal diameters. In addition, the total subsidence over a. period of five years before collapse was about the same for each sinkhole. A significant similarity exists among the rock surface gradients of the three cases. Each gradient was about 2.5 inches per 100 feet just prior to sinkhole development. (See Neito-Pescetto and Hendron, 1977, p. 48.)

The similarities between the Grosse Ile and Windsor sinkhole formations are not surprising in view of the nearly identical stratigraphic sections of the two sites and the similarities in the salt production methods. This implies that structural modeling of sinks and prediction of future sinks will be much more successful in areas where one or more collapses have already occurred. Taken together, the Windsor and Grosse Ile sinks represent one of the best and most complete sets of data available for future model development. 


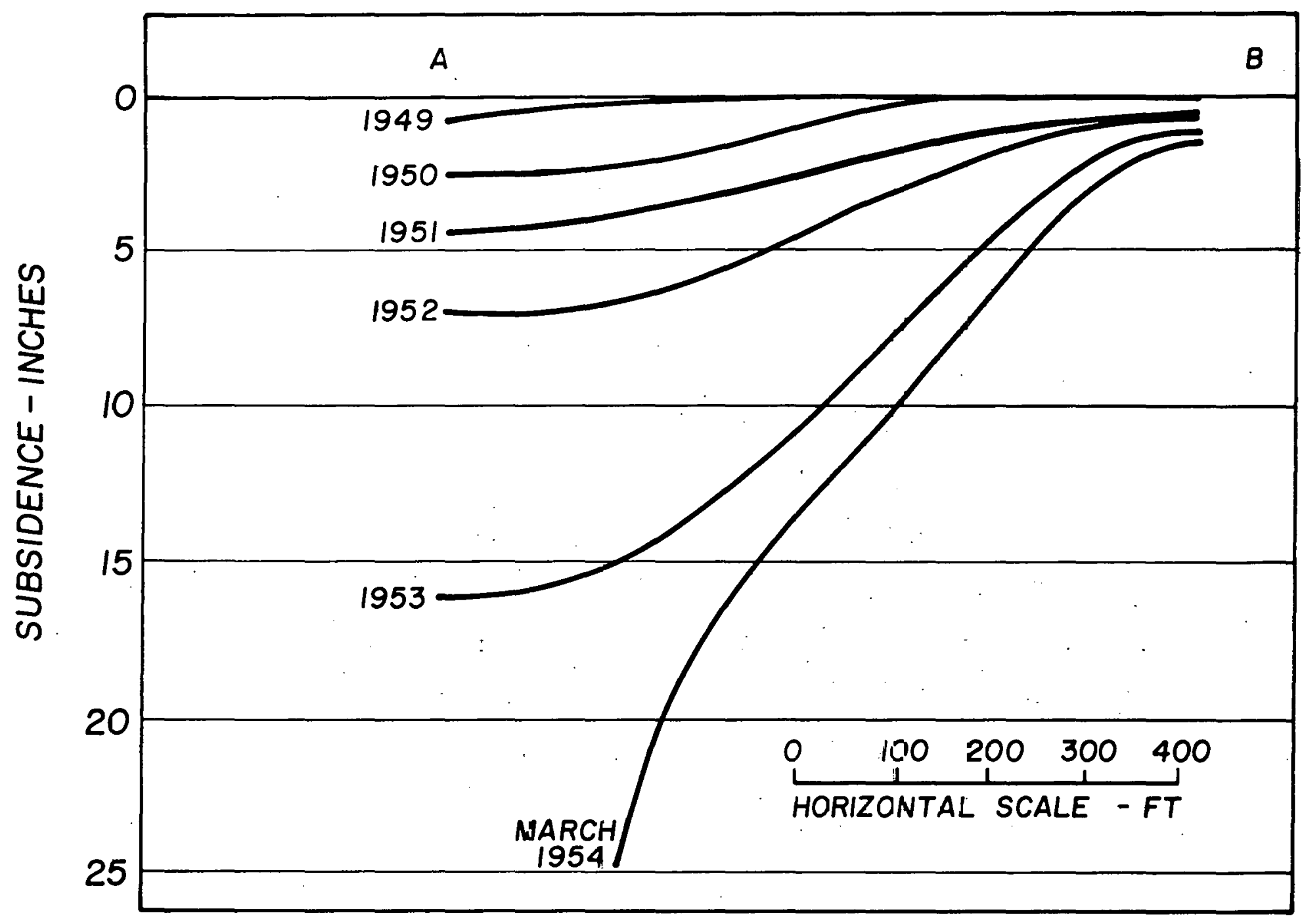

Figure 4.2.3. Profile Through the Nesterly Portion of the Subsidence Area at Windsor (After R. Terzaghi, 1970). 


\subsection{Hutchinson, Kansas, Subsidence, 1925}

\section{Introduction}

A slow subsidence of the downtown section of Hutchinson, Kansas was observed in 1925. This ground movement was attributed to the collapse of a salt cavity formed by five brine wells that were being operated by Carey Salt Company in the area. Minimal structural damage; including cracks in the walls, was observed at the courthouse. Surface cracks in the pavement were also observed. (See Walters, 1978, p. 16-17, Young, 1927, p. 811-812.)

\section{Stratigraphy}

Hutchinson, Kansas, rests on approximately 8 feet of top soil overlying a 60- to 100-foot-thick layer of water-bearing sand and gravel. Below this lies a 340-foot-thick layer of the Red Beds shale. Approximately 310 feet of Hutchinson Salt is found beneath the Red Beds. This salt is interbedded with shale that varies in thickness of up to 7 feet. ". The shale content of the salt is about 25 percent. (See Young,. 1927, p. 810.)

\section{Subsidence}

Indications of ground movement were first observed on February 24, 1925 when a supply. pipe for Carey. Salt Company's well No. 2 broke. Soon afterwards, production was terminated. Figure 4.3 .1 shows the location of the five wells. By February 27, 46 observation points were identified and elevations recorded so that the horizontal and vertical movements could be monitored. Surveys were taken between February 27 and May 22, 1925. Vertical displacement wds cenlered around well No. 2, with the grcatest change of elevation observed around an 8-inch sanitary sewer that ran between Avenue $B$ and Avenue $C$. Here, a maximum vertical displacement of approxmately one foot was observed. Horizontal movement of the east end of the courthouse was approximately 2.5 inches. Young (1927) plots elevation change as a function of time at locations where subsidence was evident. Figure 4.3.2 illustrates the change in elevation at four of these 1ocations. By May 22, subsidence had practically ceased. A series of circular cracks extended outward from well No. 2 for a distance of approximately 600 feet. Since it appeared that the subsidence was centered around well No. 2, an exploration rod was lowered into the well to determine the 


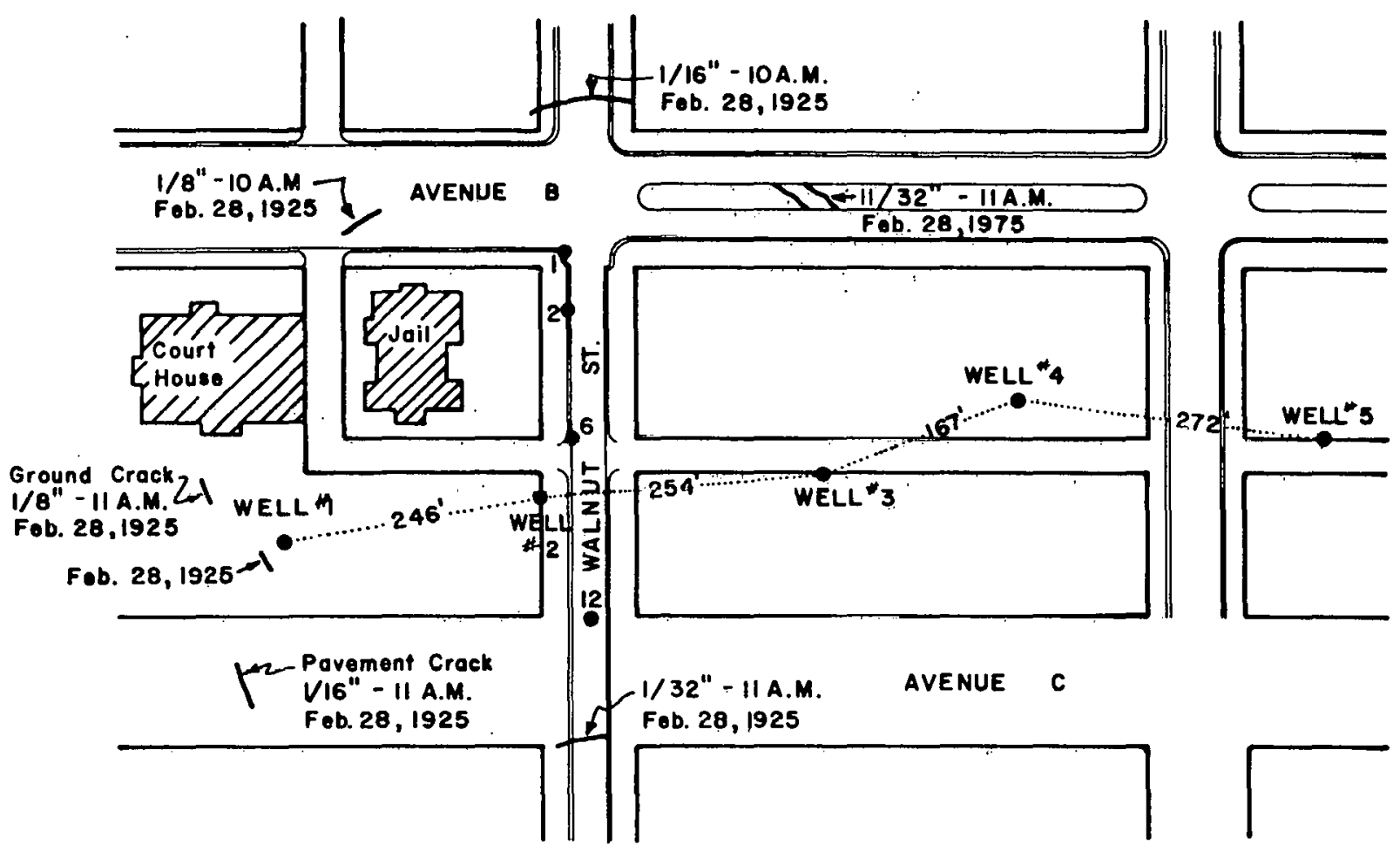

Figure 4.3.1. Location of Brine Wells and Surface Cracks in Hutchinșnn, Kancas (After Young, 1927, p. 811). 


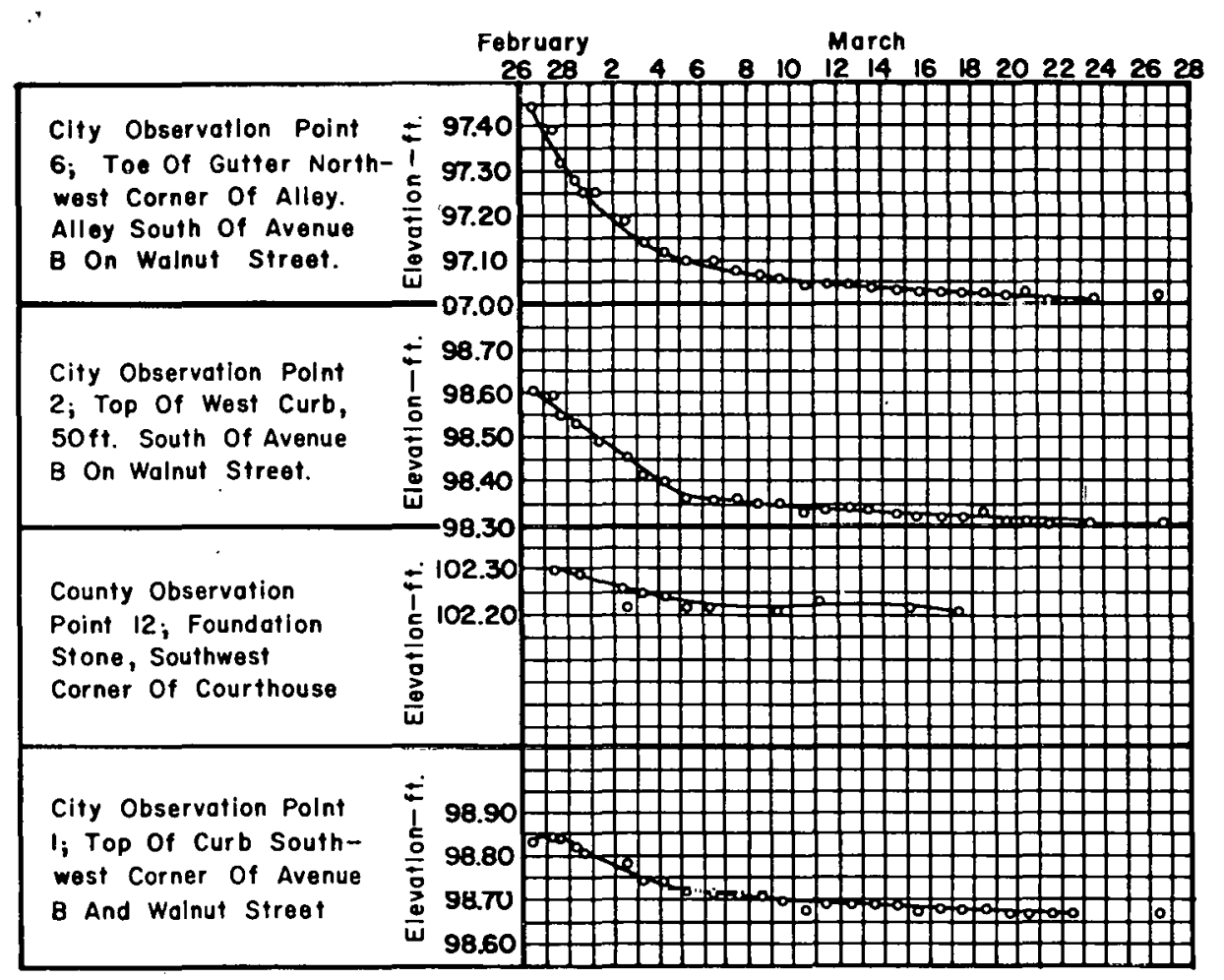

Figure 4.3.2. Surface Subsidence as a Function of Time at Various Observation Points in Downtown Hutchinson, Kansas, 1925 (After Young, 1927, p. 813). 
upper limit of the chamber. This survey indicated that the tubing was broken off near the 290-foot level and that the top of the debris pile was at the 365-foot level. (See Young, 1927, p. 811-814.)

\section{Well Descriptions and Cavity Dimensions}

Walters (1978a, p. 16-17) indicates that the 5 wells were drilled for brine production with well No. 2 subsequently being used as a fresh water inlet for well Nos. 1 and 3. Young (1927, p. 815), estimated that each well had created a cavern of approximately 235,000 cubic feet. The shape of the cavern produced by each well was not known, but it was determined that well Nos. 1, 2, and 3 were connected underground. Althnugh a pear= shaped cavity is usually formed in solutioning operations, Young (1927, p. 816 ) indicates that the shale beds may have modified the leaching process and created broader chambers.

\section{Conclusions}

Perhaps the most important aspect of this case history is that a fairly rapid ground subsidence was arrested and stabilized simply by ceasing the production of salt from the gallery. Apparently rapid subsidence does not always and inevitably lead to surface collapse and the formation of a sinkhole. 


\subsection{Barton Salt Co. Subsidence, Hutchinson, Kansas, 1952}

\section{Introduction}

The ground north of the Barton Salt Company plant at Hutchinson, Kansas, began to subside in June, 1952. The area that subsided was centered above an old G\&H Salt Company well that had been solution mining the underlying salt. Development of the resulting shallow sinkhole is believed to have been caused by the deterioration of underlying shale formations, the opening of tensile cracks, stoping, and finally the downward movement of the more or less intact shale mass. Borehole tests in and adjacent to the sinkhole and subsequent laboratory tests performed on core samples confirm these conclusions, as does the gradual deformation of a building located on the site.

\section{History of Sinkhole Formation}

The Barton Salt Company plant is located near the southeast city limits of Mutchinson in Reno County; Kansas. In 1972, Cargill, Inc. purchased the Barton Salt Company and currently operates the salt plant (Figure 4.4.1). When the sink began to form in June, 1952, water entered the bottom of the hole. It was noticed that well 60 , located more than 1000 feet south of the sinkhole, was associated with the caving taking place north of the Salt Plant building. When well 60 was turned off, this water infiltration stopped. Well records indicate that an old G\&H Company well was located in the sink area, believed to be near the center of the depression and 1100 feet north of well 60 (Figure 4.4.1). Plant operators also thought that wells $7,8,58$, and 59 were linked with a dissolution gallery that connected the subsidence area with well 60. When the G\&H well was re-entered and plugged in June, 1952, tools reportedly dropped from the 150-foot depth to the 250-foot depth. This occurrence indicated that a chimney may have formed by successive roof falls (stoping) above the cavern which was formed by salt dissolution formerly located below 400 feet. (See Walters, 1978a, p. 17.)

As late as 1974, gradual subsidence was continuing in the sinkhole area. This is evidenced by the differential settling of a warehouse built ten years after the major subsidence and by other slight deformations noticed north of the plant. 


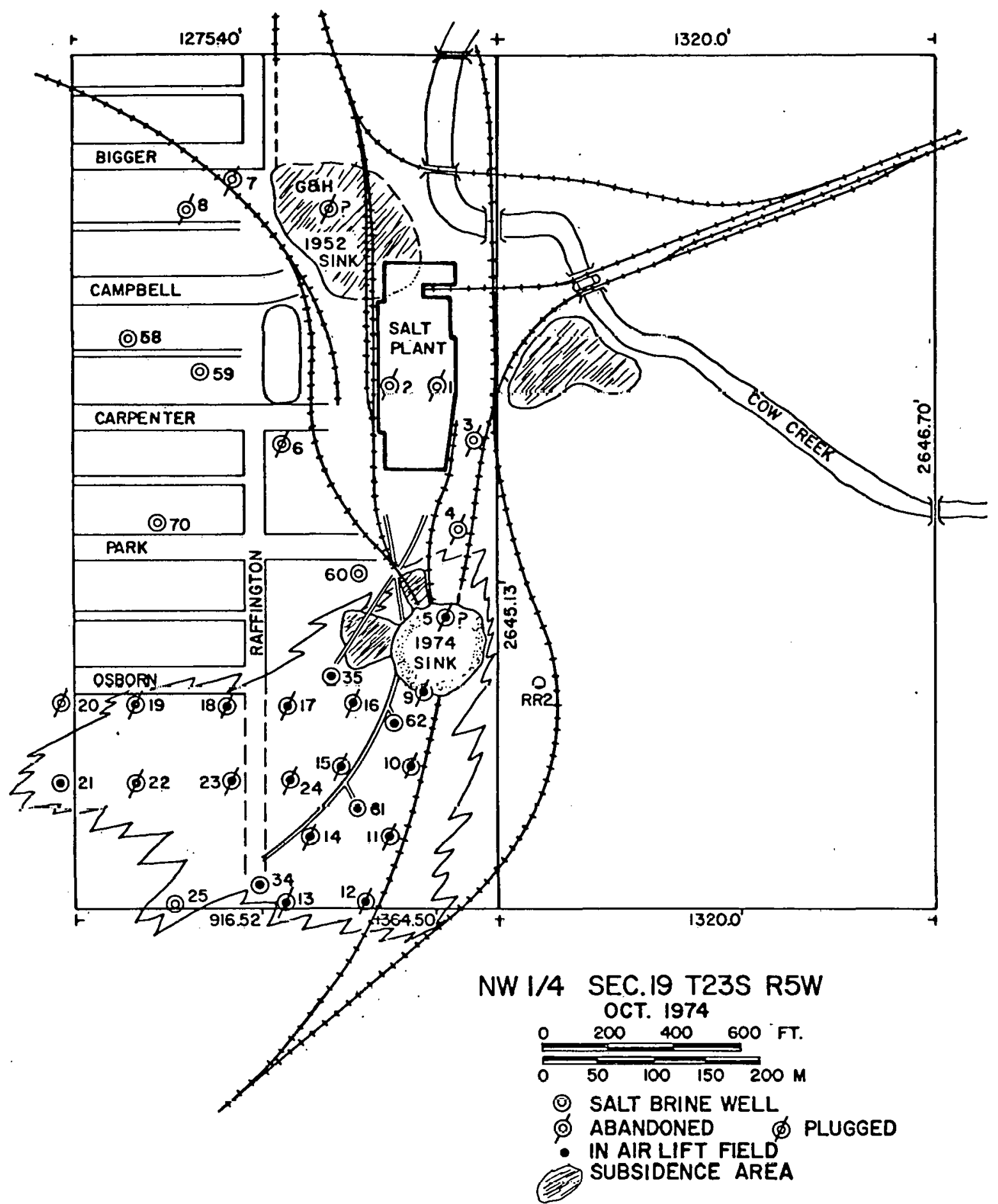

Figure 4.4.1. Map Showing the Cargill Salt Plant, Subsidence Areas, Sinkhole, Airlift Field, and Brine Wells in the HW/4 of Section 19, Township 23 South, Range 5 West (After Walters, 1978a). 
Investigations of Sinkhole

The results of field tests, including drilling, coring, and gammaneutron logging, were presented in a report by Hendron and others (1979). The observations and results of these tests are summarized in the following section.

A series of boreholes was drilled in the subsidence area (Figure 4.4.2) in an effort to determine the subsurface rock conditions to interpret the mechanisms of the sinkhole formation. Borings S-1 through S-6 are shallow and extend only through the overburden to the surface of the bedrock. These holes were drilled to determine the extent of the subsided area and also to help in selection of deeper borings. Five deep borings, $V-1$ through $V-5$, were then drilled to obtain more detailed information on the rock properties in the sinkhole area.

\section{Stratigraphy}

The stratigraphy of the undisturbed area around the sinkhole is best represented by borehole $\mathrm{V}-5$, which was drilled outside of the subsidence area. A few feet of top soil and fill were encountered before 70 to 75 feet of clean alluvial sands were reached at a depth of 8 feet. Below this surface layer, red Permian shale bedrock extends downward to 180 feet. A transition zone of red and gray shale lies between 180 and 210 feet. The underlying dark gray shale contains thin layers of fibrous gypsum, anhydrite, and argillaceous limestone. At a depth of 423 feet, rock salt was encountered. This salt has interbeds of shale and anhydrite up to 1 foot in thickness. Thin shale partings are also present at this depth. The various shales composing the bedrock recovered from borehole V-5 were judged to be competent and of excellent quality. (See Hendron and others, 1979, p. 8-9.)

\section{Results of Testing}

The results of the borehole probes show a sinkhole about 25 feet deep and approximately 240 feet in diameter. Presuming that the various layers of intact rock were flat-lying before subsidence occurred, Figure 4.4.3 shows the downward deformation of the strata. Zones of very rapid drill penetration, numerous rod drops, and zones of lost circulation can be seen 


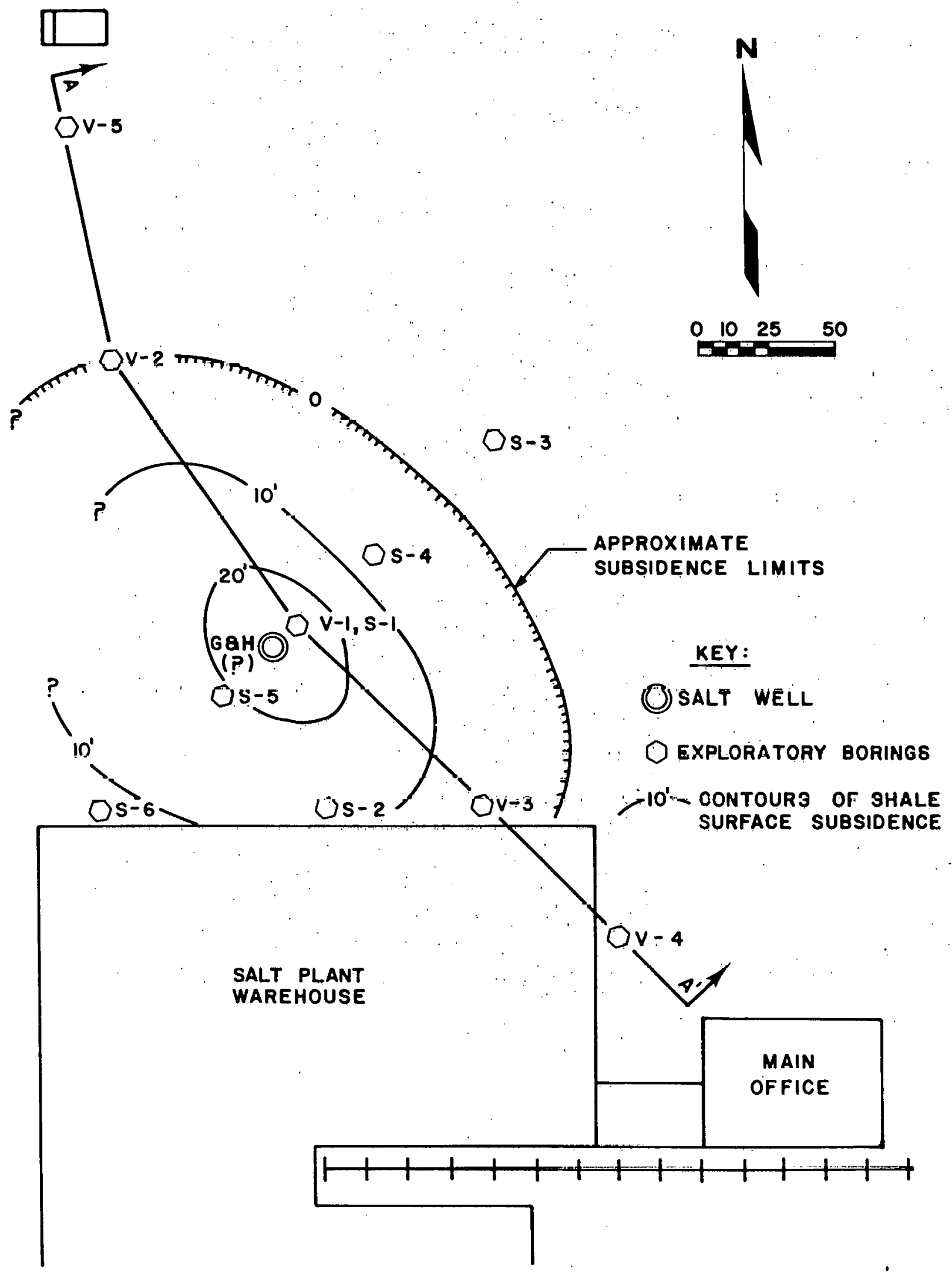

Figure 4.4.2. North Boring Layout for the Barton Sinkhole (After Mendron and others, 1979). 


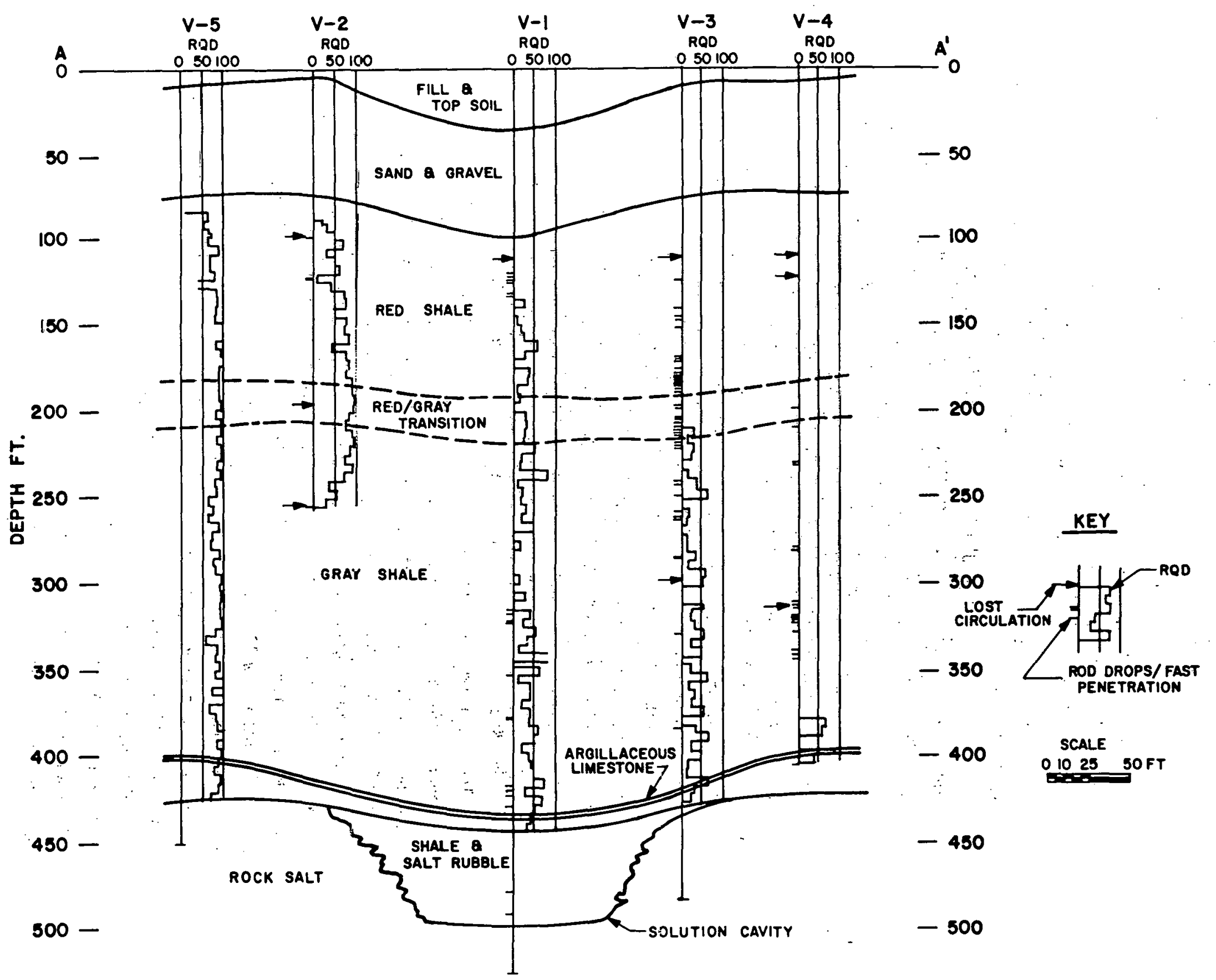

Figure 4.4.3. Nortn Boring Results for the Barton Sinkhole (After Hendron and Others, 1979). 
in borings $V-1, V-2$, and $V-3$. Cores recovered from these zones show very soft, weathered shale or brecciated and weathered shale. Also included in Figure 4.4.3 are the RQD's from the borings which were cored. (See Hendron and others, 1979, p. 7-8.)

Laboratory tests on the core samples show that the intact shales have a moderately high compressive strength (1800 to 3500 psi), but when the shales come into contact with water, they deteriorate rapidly (Hendron and others, 1979 , p. 24, 26).

Merhanisms

The formation of the sinkhnle on the fargill plant site is thought to be a culmination of several processes, including the deterioration of the shale overlying the solution cavity, the opening of tensile cracks, stoping, and the eventual downward, movement of the more or less intact shale mass. The discovery from boring $V-1$ that the cavity roof (intact shale) was in contact with the roof-fall rubble filling the cavity indicates that the cavity roof contained no salt and that about 20 feet of roof shale had fallen into the cavity. Laboratory tests showed that the shale. possessed moderate to very low durability and slaked readily when immersed in fresh or salt-saturated water. Examination of the fresh shale cores showed that the shale had little tensile strength perpendicular to the bedding and low shearing strength along the bedding. These characteristics caused subsequent softening of the shale roof and the overstressing of the lower shale beds so that near vertical tensile cracks opened in the shale above the roof. These cracks allowed wetting of the upper shale beds and caused a reduction in strength and a loss of the roof's ability to span the cavity by arching. (See Hendron and others, 1979, p. 28-29.)

Another explanation of the $G \& H$ well subsidence involves the well's connection with others wells $(7,8,58,59,60)$ in the area. Just before and during the subsidence the G\&H well spouted water or brine. The well quit flowing and subsidence occurred upon shutdown of some of these wells $(7,8,58,59$ or 60$)$. Mining in the well gallery may have caused dissolution of salt near the G\&H well, enlargement of the roof span, and deterioration of the roof. A combination of this series of events may have caused the roof rock to lose its ability to span the distance overlying the cavity and collapse. (See Hendron and others, 1979, p. 30.) 
It is not known for sure which mechanism or combination of mechanisms caused the 1952 subsidence at the Cargill plant site. Future subsidence may result from further consolidation of the roof fall rubble if additional deterioration of the shale and further dissolution of the salt blocks occurs. Slow settlement can be seen in the warehouse building that is located on the subsidence site. Other settlement in the north part of the plant is evident by misfitting sliding doors, sandfill occasionally required in the driveway, and the westward tilt of the truck loading dock (Walters, 1978a, p. 17). 


\subsection{Cargill Subsidence, Hutchinson, Kansas, 1974}

Introduction

In 1974 a new sinkhole developed in the brine field of the Cargill salt processing plant (previously Barton Salt Co.) near Hutchinson, Kansas. The subsidence occurred over a three day period, the apparent result of solution mining activities. Well records indicated that there were abandoned salt wells in the area of the subsidence (Walters, 1978a, p. 17). Included in this report are the studies of several authors who investigated the mechanisms of the subsidence.

\section{Stratigraphy}

Figure 4.5.1 depicts the geological conditions that underlie the Cargill salt processing plant. A borehole drilled on the northwest bank of the sinkhole, designated $V-3$ in Figure 4.5.2, yielded a typical section of the sediments underlying the sinkhole area which is, of course, nearly identical to the stratigraphy described in the previous section of this report. The upper 70 feet consists, of loose Pleistocene sand, with grain size increasing downward to $3 / 8$-inch diameters in the lower two feet, Beneath the sand layer is 10 feet of soft Permian shale which showed evidence of swelling from water absorbtion. A hard, red shale is found at depths of 80 to 190 feet, with thin qypsum layers in the lower 10 fect, $A t$ depths of 190 to 205 . fect a zone of allernallng red and gray shale layers exists. A competent, gray shale was encountered from 205 to 242 feet. A 5-foot fractured and deteriorated zone is found at 242 feet. The competent, gray shale is once again continued to 420 feet, with thin layers of gypsum and 8-inch anhydrite layers present. At 420 feet the Permian Hutchinson salt is reached. Gray shale layers can be found throughout the salt zone. A 2.5-foot-thick void is found at the 480-foot level. The salt layer is solid to the 527-foot level, with the exception of dark and light: layerèd salt from 512 to 527 feet. (See Walters, 1978a, p. 79-80.)

\section{$\underline{\text { History }}$}

The location of the sinkhole is just south of the Cargill plant near the southeast city limits of Hutchinson, Kansas. Many abandoned salt wells 


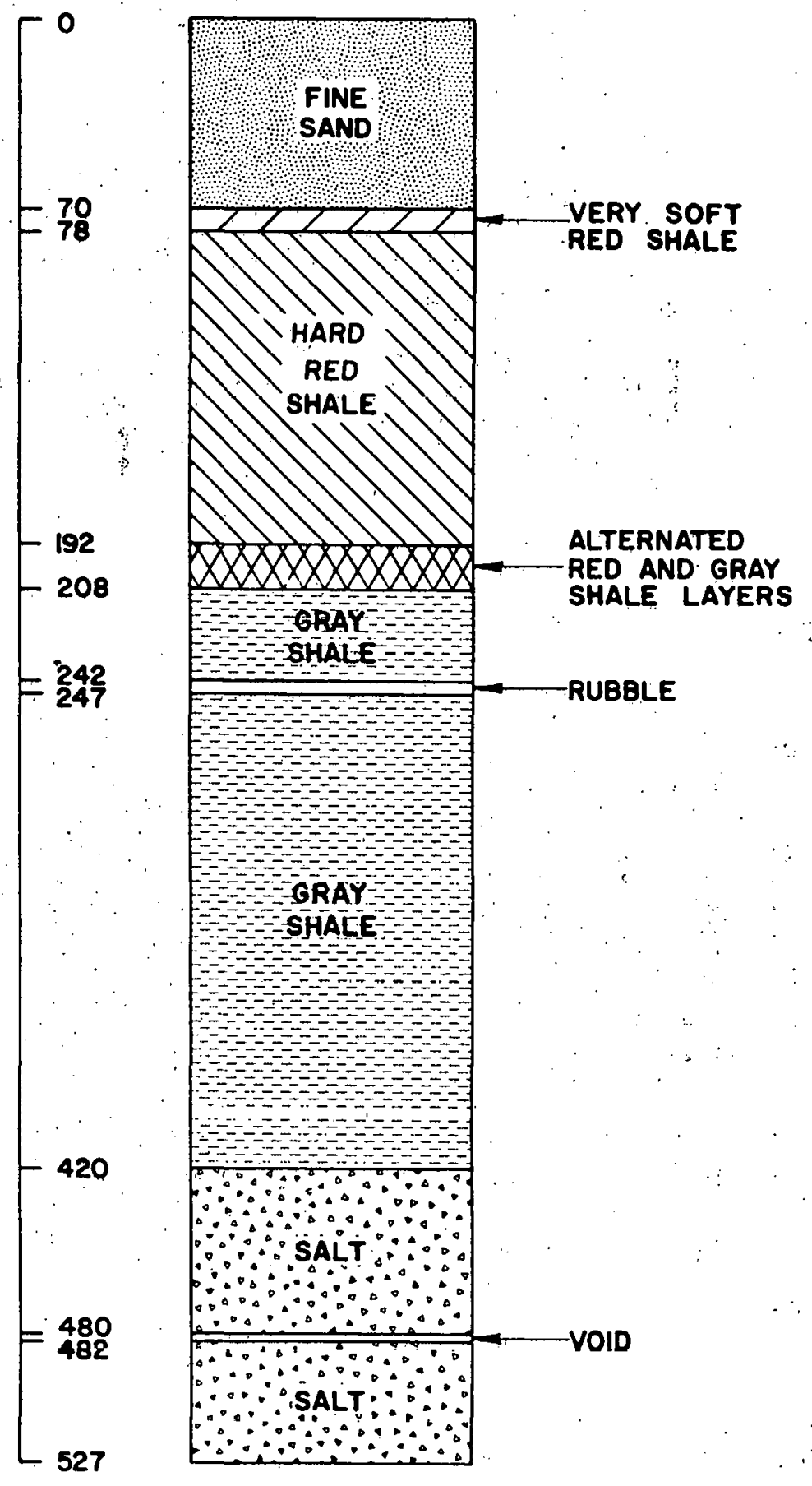

Figure 4.5.1. Typical Geologic Section Underlying Cargill Salt Plant. 


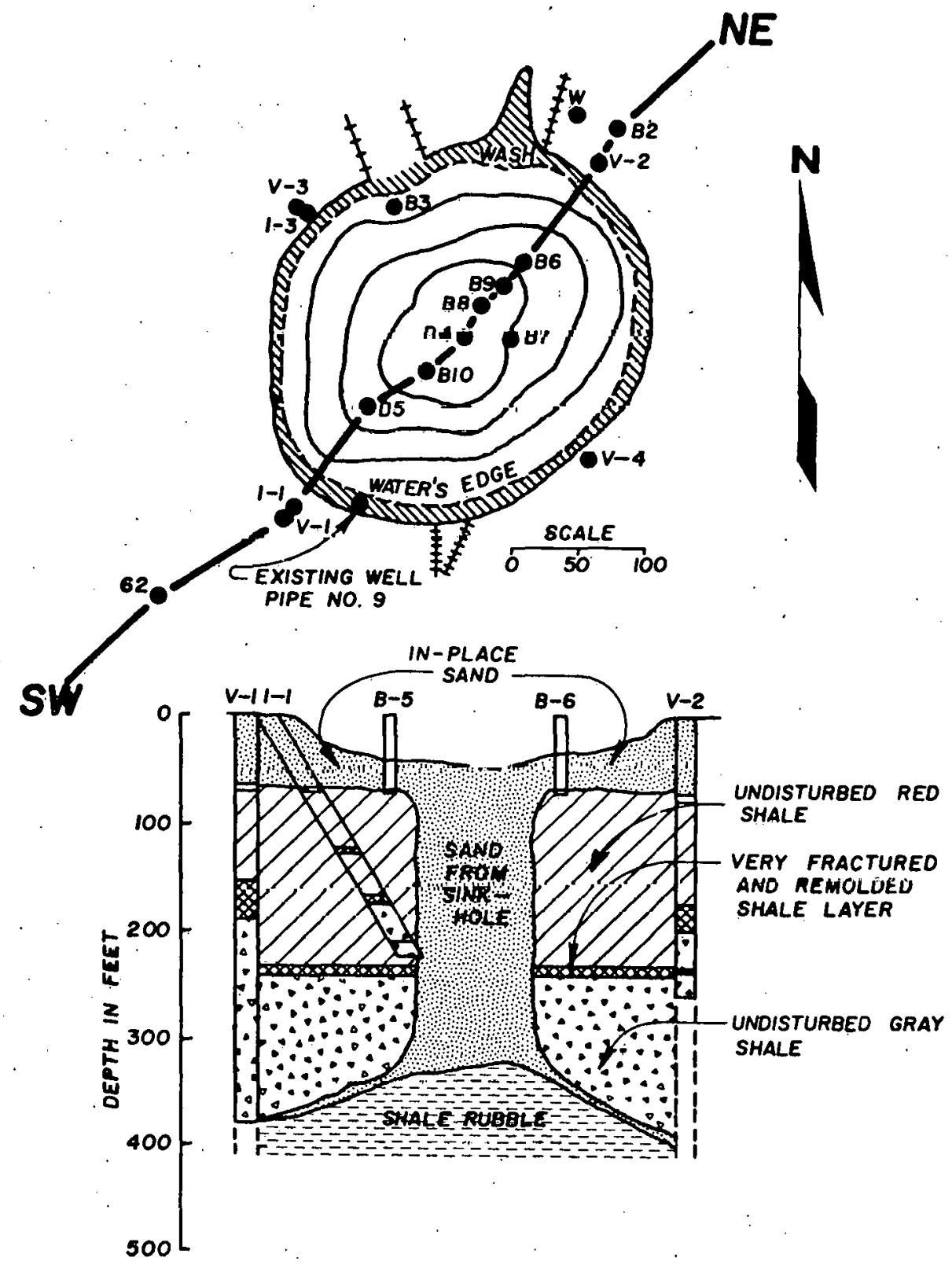

Figure 4.5.2. Index Map and Conceptual Sketch of the Cargill Sinknole, Showing Underground Conditions aiong a Northeast-Snuthwest. Cross Section (After Valters, 1978a. Prepared for the Solution Mining Research Institute by Hendron, Heuer, and Fernandez-Del gado, June 13, 1977). 
are thought to exist in the area where the subsidence took place, but exact locations are not known because of a lack of records from the time that these wells were operated.

Company records indicate that at least one abandoned salt well is located within the perimeter of the sinkhole. : This well was drilled in 1914, and records show that in 1924 it was repaired and was being used as a return brine supply well for several other wells. The well was abandoned and plugged in 1928. (See O'Connor, 1975; p. 9.).

\section{Sinkhole Formation}

The sinkhole was first observed to be forming around 8:00 a.m. on October. 21, 1974, beneath the Missouri-Pacific Railroad's WichitaHutchinson tracks. The tracks were left suspended in the air as the sinkhole deepened. A rolling motion of the water within the sinkhole was reported by Cargill personnel at the time the sinkhole was first observed. The rolling motion quieted when wells near the sinkhole being operated by the airlift. method were closed down. Communication between the sinkhole and the wells in the "air lift" field was indicated by this occurrence. By noon the sinkhole had a diameter of about 200 feet. The sinkhole was stabilized by noon on October 23 with a diameter of 300 feet. The walls of the hole were nearly vertical. Walters (1978a, p. 26) reports that the volume of the sinkhole was calculated to be 90,000 cubic yards. The water which had entered the hole was 21.5 feet below the ground level and 37.5 feet deep at its deepest point. Water sampled during the collapse had a chloride content of 87,000 to 89,000 parts per million, which indicates that some dilute brine had entered the sinkhole (0'Connor, 1975, p. 10). On December 5, 1974, the concentration was 1525 parts per million, indicating that brine which had entered the sinkhole had been replaced by ground water.

Three wells, 61, 62, and 34, in the air lift field were being operated as a gallery with well 35 at the time the crater began forming. Figure 4.5.3 shows the approximate locations of these wells. Wells 61,62 , and 34 were being used for the disposal of waste solids, including calcium sulfate and magnesium chloride-enriched brine. Gravity was used to flow the wastes down well 34 into the cavity which interconnected all four wells and moved towards well 35. After the heavier solids settled out, the upper flow 


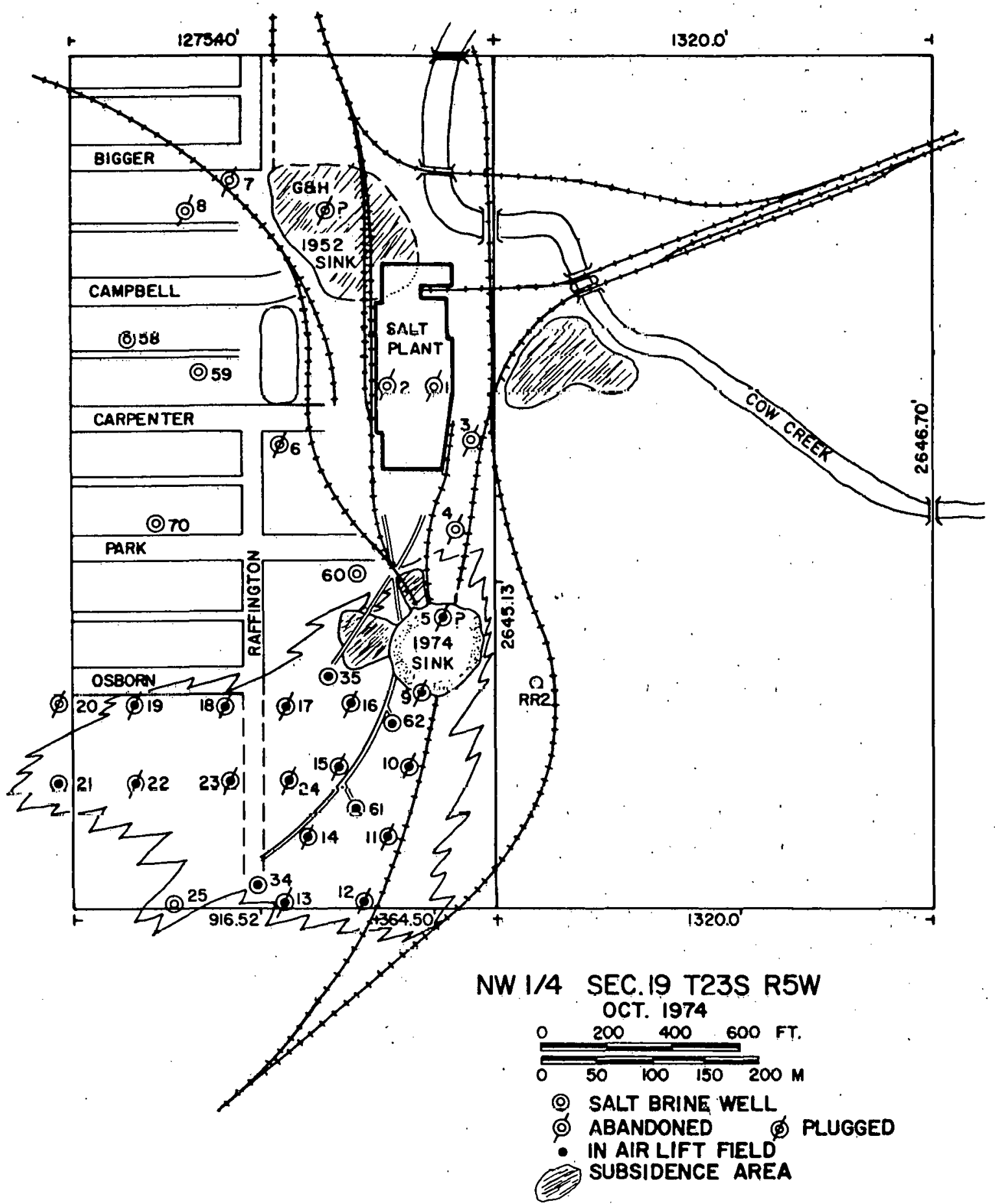

Figure 4.5.3. Nap Showing the Cargill Salt Plant, Subsidence Areas, Sinkhole, Airlift Field, and Brine Wells in the NW/4 of Section 19, lownship 23 South, Range 5 West (After Walters, 1978a). 
water was removed through well 35 by the airlift method to brine storage tanks. Air, with enough pressure to escape from the bottom of a small tube extending into the fluid of well 35, was the likely cause of the rolling motion reported by the Cargill personnel. When the air lift was shut down, this motion quieted. After the sinkhole formed, some tubing was removed from the four wells. Because of the crookedness and small size of the holes, it was, impossible to $\log$ the wells. (See Walters, 1978a, p. 20-21.)

The formation of the sinkhole caused no disruption of plant operations. The only damage was to Missouri-Pacific's main line tracks." No principal water lines were disrupted and no buildings. were damaged.

\section{Post-Subsidence Activities}

Activities conducted after the subsidence included core drilling and seismic surveys requested by Missouri-Pacific so that they could reroute their main line, water quality testing by the State of Kansas Department of Health and Environment, and borehole drilling by the Solution Mining Research Institute to investigate the mechanisms of the subsidence.

Two testholes drilled for Missouri-pacific to the 250-foot level encountered shale bedrock at 68 feet. A third hole drilled in salt to 519 feet revealed no cavernous conditions. This hole was used for a limited refraction seismic survey which showed void spaces due to salt dissolution in the airlift field area and in a poorly drained low area east of the salt plant, indicated on Figure 4.5.3. These tests corifirmed that an area east of wells 10, 11 , and 12 contained no cavernous conditions and was competent enough for the new tracks: (See Walters, 1978a, p. 23-24.)

The State of Kansas Department of Health and Environment made a series of well tests to determine chloride contamination of ground water. Samples collected from 39 water wells in the area on 0ctober. 24 and 25, 1974 showed chlorides present averaging $367 \mathrm{ppm}$. In November, more tests showed $488 \mathrm{ppm}$ to $52,000 \mathrm{ppm}$ chlorides. Chloride contamination was only evident initially, and as of February, 1976, no further contamination was noted. (See Walters, 1978a, p. 24.)

The Solution Mining Research Institute (SMRI) had a series of holes drilled in the sink area in November, 1975. The results of these drillholes revealed that stoping of underlying shale beds produced' a collapse with a diameter of approximately 100 feet. The surface sink enlarged to 
approximately 325 feet in diameter as a result of sloughing of the loose sand and gravel above the bedrock.

Causes and Mechanisms

Salt has been mined in the Hutchinson area since 1888. The older methods of uncontrolled dissolution mining, in which fresh water was pumped down a central tubing and brine forced up through the casing annulus, left cavities of unknown extent. The location of many old cavities is not even known due to the abandonment of old wells and missing well records. This sinkhole developed in an active brinefield which included operating and abandoned wells and mined cavities of unknown size. (See Waltẹs. 1978a, p. 25-27.)

Walters (1978a) investigated the possible causes and mechanisms of the 1974 collapse on the Cargill property in 1977. A series of borehole testing was conducted at the plant site, and the results of these investigations are contained in a report by Hendron, Heuer, and Fernandez-Delgado (1978). The following section makes extensive use of the data contained in these reports.

Four vertical boreholes $(V-1, V-2, V-3, V-4)$ and two inclined boreholes ( $1-1$ and $1-3,30^{\circ}$ from vertical) were drilled into the rock strata beneath and in the vicinity of the sinkhole. The location of these boreholes is illustrated in Figure 4.5.2. This figure is based on data collected from borehole $V-3$ because of the excellent recovery of the core.

Boreholes $V-3$ and $V-4$, located 300 feet apart, both encountered salt at 420 feet. Some dissolution of salt was apparent in the subsurface; but no massive cavity was found.

Boreholes $V-1$ and $V-2$ showed evidence of disturbance and voids in the gray shale from 240 to 245 feet. At 388 feet a void containing sand was found in borehole $V-1$. Walters (1978a, p. 81) concludes that these dat.a indicate that an elongated cavity running southwest-northeast under the sinkhole had formed among the brine wells, caused by dissolution activities. The length of the gallery may be greater than 1300 feet, which may have exceeded the span capabilities of the shale layers above the cavity.

Measurements indicate that about 30 feet of the roof shale in borehole $V-1$ had collapsed downward. Movement of large blocks of rock were noted 180 feet above the cavity. The sand-filled chimney, illustrated in Figure 
4.5.2, is centered below the sinkhole from 70 to approximately 370 feet. Studies of the region below the sinkhole reveal some important features. These include: 1) a vertical, sand-filled, roof-fall chimney, 2) bedding plane dilation cracks in the Permian shales due to slight downward movement of large shale blocks, 3) open solution voids extending vertically up to 2.5 feet in the upper salt beds, and 4) a iarge solution cavity, which has been plugged, with roof-fall rubble (Walters, 1978a, p. 81).

Although the exact cause of the sinkhole is not known, a theory based on the mechanism of stoping: appears plausible. A solid roof rock, overlying an old well bore and previously solutioned cavity, begins to separate and fall because of inadequate support. Overlying layers are in turn exposed, break off, and fall downwards, filling the void previously left from salt solutioning. The upward stoping of the shale causes a coneshaped rubble pile to form along the well bore. As the loose materials continue to migrate downwards, the inadequately supported roof rock collapses, forming a sinkhole on the surface.' (See Walters, 1978a, p. 80-81.) 
4.6. Interpace Corporation - Carey Salt Division, Subsidence, Hutchinson, Kansas, 1978

\section{Introduction}

Two different subsidence areas formed around separate brine wells in the Carey brinefield in 1978. The wells are part of a gallery connecting other wells. There was no damage to plant property, and only a brief interruption in plant operations. The two craters are the result of the development of large roof spans above cavities where shale had been exposed to the brine and deteriorated from well operation. Roof collapse and. sagging of the shale above the cavities caused the surface subsidence.

\section{Stratigraphy}

Figure 4.6.1 gives a typical section of the geology underlying the Hutchinson area. The upper 70 feet of the area where the Carey Salt plant is located consists of loose Pleistocene sand with a few feet of topsoil. Beneath the sand layer is 10 feet of soft, Permian shale. A hard, red shale is found at depths of 80 to 190 feet, with thin gypsum layers in the lower 40 feet. Competent, gray shale is found to a depth of about 400 feet, where the Permian Hutchinson salt begins. The salt bed is between 300 and 325 feet thick, interbedded with flat-lying layers of shale, anhydrite, and carbonates, comprising 15 to 20 percent of the salt formation.

\section{History}

The Carey brinefield has been in production since 1909. The salt plant and brinefield are located southeast of the city limits of Hutchinson, Kansas. As of 1978, there were a total of 108 salt wells drilled on $300-$ foot spacing. (See Walters, 1978b.) Figure 4.6 .2 shows the location of all of the brine wells in the vicinity of the subsidence. The wells in the vicinity of the well gallery, 50 to 57, where the subsidence took place, were drilled in the early $1940^{\prime} \mathrm{s}$. They are operated by pumping water down tubing to around 700 feet under a well head pressure of about 40 to 100 psi and forcing brine back up the annular space between the tubing and the casing. Some of the wells were operated by reversing this method and 


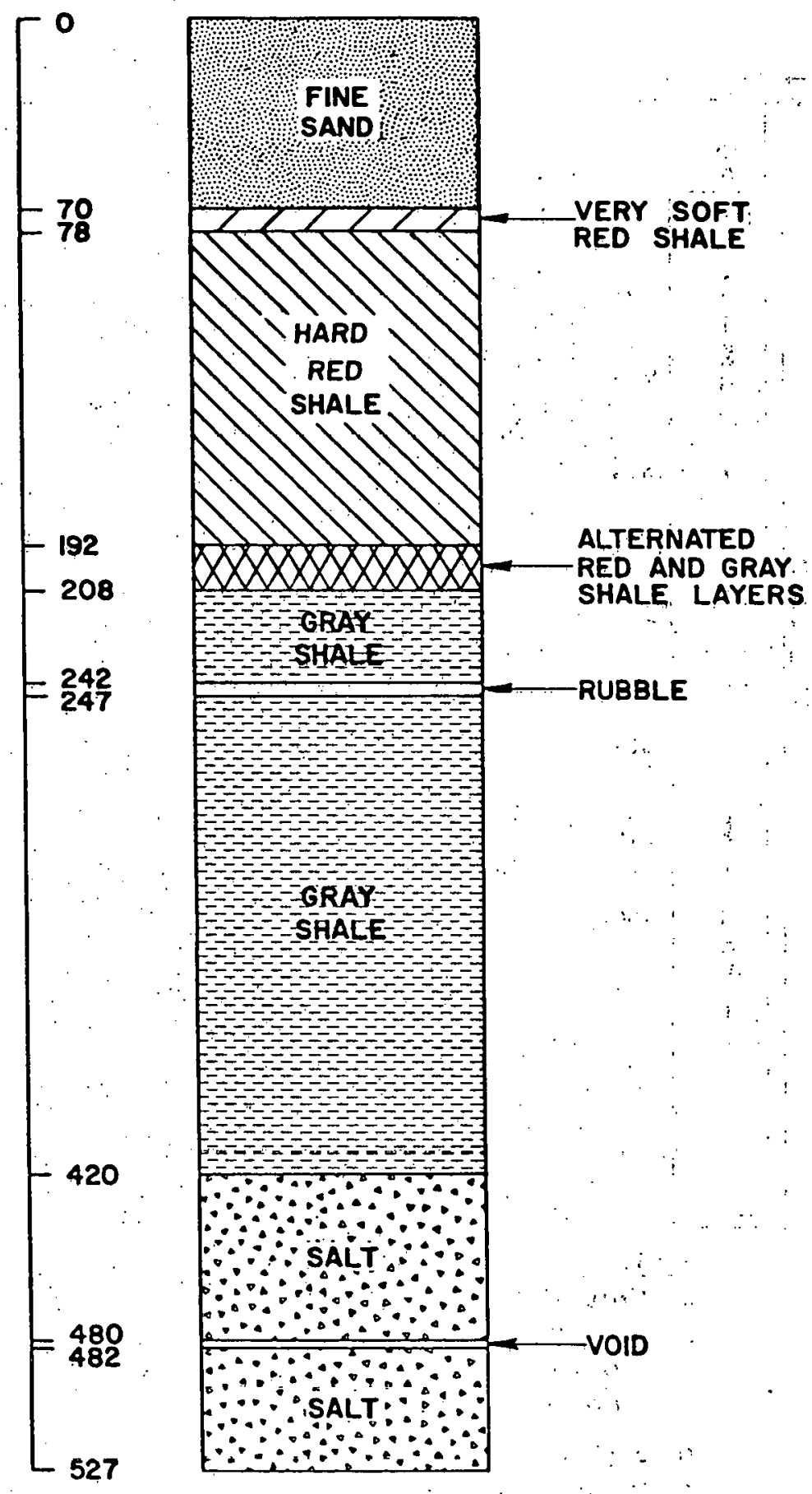

Figure 4.6.1. Typical Geologic Section Underlying Carey Salt'Plant. 


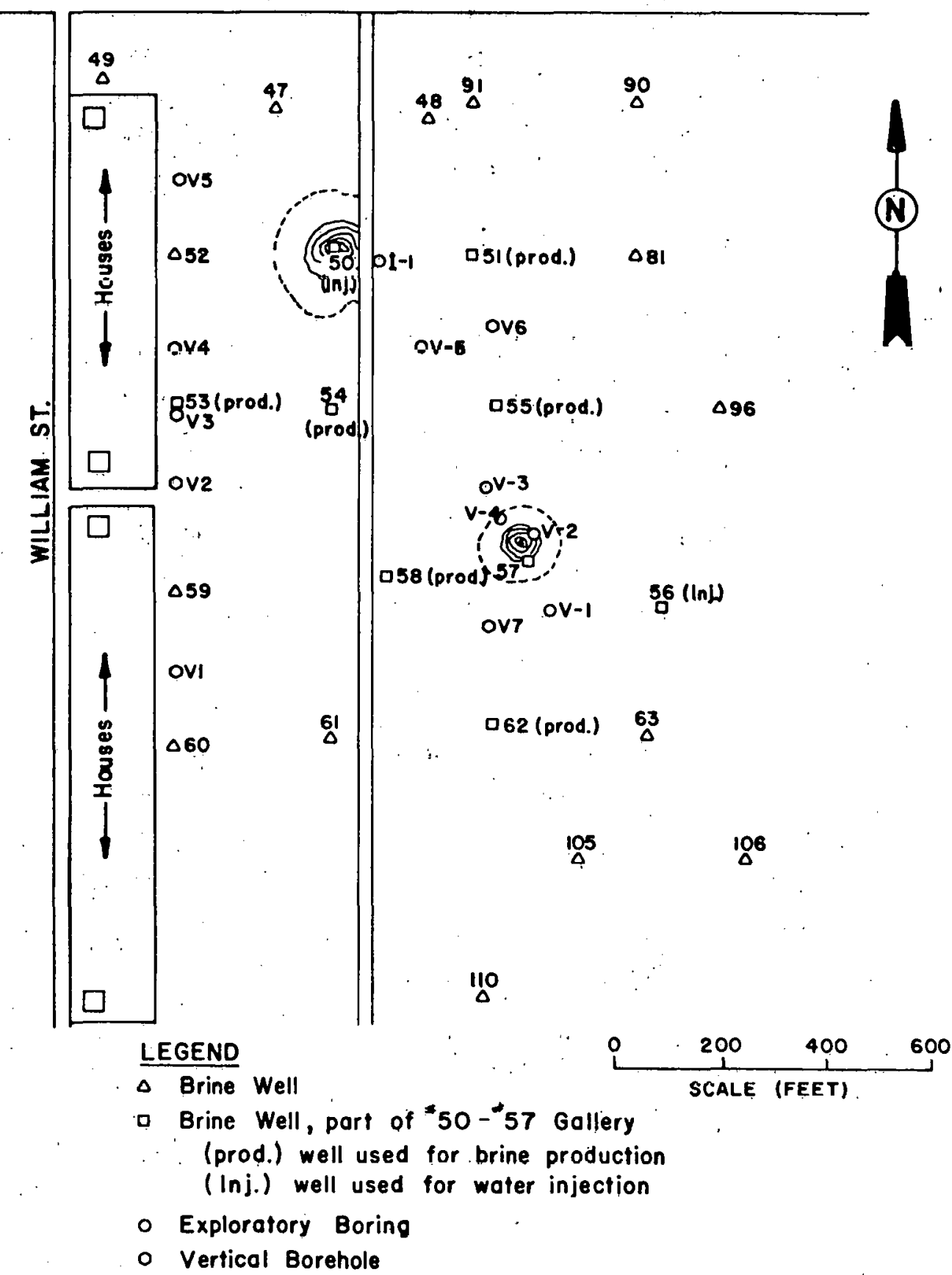

Figure 4:6.2. Brine Well and Boring Locations of Carey Salt Brine Field (After Hendron and others, 1980). 
pumping water down the annulus and returning it through the tubing. (See Hendron and others, 1980, p. 3-4.)

\section{Subsidence Activity}

On May 31, 1978, the first sign of subsidence was noted when a water line broke near well No. 57. This well was part of a gallery of nine interconnected brine wells. Fourteen months earlier these wells had been abandoned, but not plugged. The subsidence around well No. 57 continued until June 2, 1978. The circular depression which formed had a diameter of 117 feet and a maximum depth. of about 10 feet. The estimated volume was 1500 cubic yards. About a week later, on June 7, 1978, a second larger subsidence area started to form. First a water line broke near well No. 50. It was repaired, but broke again on June 8,1978 . This subsidence area continued to form around well No. 50 until June 9, 1978. The dimensions of the crater, surveyed in December, 1978, were 300 feet north-south and 215 feet east-west. The maximum vertical subsidence at the wellhead was 13 feet, and the volume was about 8500 cubic yards. (See Hendron and others, 1980, p. 6-7.) A pond was formed and the wellhead equipment, in a vertical position, was covered with water (Walters, 1978b).

\section{Investigation of Subsidence}

The results of investigations of the causes and mechanisms of the Carey brinefield subsidence are included in a report by Hendron, Fernandez, and Lenzini (1980). The following section summarizes their findings and conclusions.

An exploratory drilling and coring program was conducted on the Carey Salt Company brinefield in Hutchinson, Kansas. Five vertical boreholes and one inclined borehole were drilled around the well No. 57 subsidence area. The location of these boreholes are shown on Figure 4.6.2, with the vertical holes designated $V-1, V-2, V-3, V-4$, and $V-5$, and the inclined hole designated I-1. In addition to the borehole drilling, a subsidence monitoring system was implemented to measure ground movement. Two of the vertical borings were established as deep settlement points consisting of $3 / 4$-inch steel pipe anchored in sound bedrock in the borehole and then extended to the ground surface. A 1.5-inch PVC casing isolated the steel pipe from the surrounding rock. These deep settlement points were 
installed to measure any movement occurring in the bedrock near the anchors. (See Hendron and others, 1980, p. 13.)

Laboratory testing of selected core samples included tests for natural water content, Atterberg Limits, slake durability, and simple slaking tests. The complete results of all of the tests conducted on the subsidence site and in the laboratory are detailed in the Hendron, Fernandez, and Lenzini (1980) report.

\section{Mechanisms}

From the data obtained from drilling and coring, the following explanation is given for the rapid subsidence that occurred above well. Nos. 50 and 57. A large, 270-foot unsupported roof span was discovered above the well No. 57 cavity. Beneath the center of the sinkhole the remnants of a rubble-filled cavity were found. The shape of the cavity.resembles an inverted cone. No salt roof was found above the well No. 57 cavity, indicating that prior to collapse the solutioning process had removed the salt up to the shale roof of the cavity. Sagging shale beds, which include extensive zones of separation between individual beds, underlie the sinkhole. The rubble discovered in the cavity appears to be supporting the shale beds overlying the roof of the cavity. A similar situation was found beneath the No. 57 well. (See Hendror and others, 1980, p. 32-33.)

Stoping is believed to have progressed to a higher elevation prior to subsidence in the No. 50 well than was apparent at well No. 57 . The shale below the crater was also characterized by sagging beds and extensive bedding plane separations.

A possible mechanism to explain the stoping of the overlying shale beds into the cavity is the fracturing of the exposed shale by the pressure of the injected water in the uncased well bore. If the pressure of the water injected exceeds the weight of the overburden, sagging may result, causing cracks to develop horizontally in the shale away from the well. (See Hendron and others, 1980, p. 33-34.) Evidence of these highly pressurized cracks was found while drilling well No. 1.06 (Figure 4.6.2) in the Carey brinefield. Brine was recovered from this well at a depth of 150 feet, indicating that a hydraulic connection may have developed between wells in the gallery through horizontal cracks in the shale beds. (See Walters, 1978b, and Hendron and others, 1980, p. 41.) 
The lower shale beds overlying the solutioned salt cavities below wells No. 50 and No. 57 evidently became the roofs of the cavities due to the dissolutioning process. This exposed the shale to fresh water or weak brine during well operation. Laboratory test results show that the shale in the Hutchinson area has low durability. and tends to swell and soften when wetted (Hendron and others, 1980, p. 30).

Hendron and others (1980) concluded that the shale layer above the cavity roof was not capable of considerable arching and stress redistribution, that would be induced when the upper salt layers were removed. The bedding separations and tensile cracks which developed in the overstressed roof rock caused biocks of shale to fall from the roof and expose the overlying shale beds to further deterioration and progressive upward failure (i.e., stoping). (See Hendron and others, 1980, p. 36.)

The uncemented casings used in old brine wells, such as №. 50 and No. 57, are thought to have aggravated the conditions in the wells by exposing a considerable length of shale to possible deterioration and fracturing by injection pressures. (See Hendron and others, 1980, p. 34-36.)

No further subsidence has been noted or is expected to occur in the area of the two wells. Because of the nature of the gallery formation connecting other wells in the area; further study was recommended to predict possible subsidence above other well cavities. 


\subsection{Cheshire Basin, Cheshire, England}

\section{Introduction}

Salt has been extracted by dry mining and brining from the two salt beds of the Keuper Marl Series found in the Cheshire Basin of west central England for over 300 years. This removal of salt has resulted in subsidence of the overlying areas.

\section{Stratigraphy}

The Cheshire Basin is a synclincal structure and spans an area approximately 30 miles to the east-west and 50 miles to the north-south (Howell and Jenkins, 1976, p. 507). Salt is found in two layers interbedded in the Keuper Marl Series of Permian-Triassic age. This series composes the upper sediments of the Cheshire Basin. Around Northwich, the upper salt layer is 216 feet below the surface, and the top of the lower bed is at a depth of 330 feet (Calvert, 1915, p. 114). Both beds are approximately 84 , feet thick in this area. Saturated and unsaturated brine is found to overlie the upper salt layer (Calvert, 1915, p. 171).

\section{Subsidence Data}

Salt production by brine evaporation in the county of Cheshire, England, dates back to pre-Roman times. Natural brine springs supplied most of the salt in this area until 1682, when the first shaft was sunk directly into the salt beds. In 1732, 5285 tons of salt were mined by the room-and-pillar method, and in 1880 the annual yield was $1,104,610$ tons. Because of poor mining practices during this period, the life of these mines rarely exceeded 40 years. Failure to provide adequate roof-support pillars in the mines caused roof collapse and the development of tension cracks in the rock strata above the mines, allowing water to flood the collapsed area. (See Bell, 1975, p. 239-241.)

Salt was removed from the upper salt bed exclusively until the late eighteenth century, when the lower salt bed was discovered. Mining operations at this level did not account for the increased weight of the overburden, and collapse and flooding again resulted. Large underground galleries were formed when the water in a collapsed mine penetrated the 
surrounding walls and pillars and came into communication with other collapsed mines. (See Bell, 1975, p. 240-241.)

In addition to the conventional room-and-pillar salt mining in Cheshire County, the "wild brine pumping" method was used to remove brine from preexisting natural brine runs. (Bell, 1975, p. 242). This technique also contributes to the formation of extensive solution galleries in the salt beds. When extensive pumping caused natural brine levels to drop, wells were sunk deeper and deeper.

Subsidence above brining operations usually forms by trough subsidence, a downwarping of the cavity roof into the cavity. When the saturated brine at the interface of the salt bed is removed, the undersaturated brine which replaces the saturated brine causes further dissolutioning of the roof salt. Further leaching into the strata directly above the cavity causes it to weaken and lose its ability to span the cavity, and subsidence occurs.

Trough subsidence above a brine run is normally concentrated in the area where fresh water enters the system (Be11, 1975, p. 242). Therefore, subsidence can occur at distances of four to five miles from a pumping station.

One million tons of rocksalt were mined in Cheshire in 1968, and 500 million gallons of wild brine and 3900 million gallons of controlled brine were extracted. In 1969, 42,340 million gallons of fresh water were pumped from the sandstone aquifers near the rocksalt areas. The resulting groundwater migration from the salt areas may have triggered subsidence in this area by disturbing the brine/freshwater interface. (See Howell and Jenkins, 1976, p. 517.)

Sinkholes, caused by wild brine pumping, have caused extensive damage to property in Cheshire county. These localized subsidence features form almost instantaneously above areas where brine runs have caused cavities to form in the underlying glacial sands. The size of these hollows are usually about 30 feet deep and 230 feet in diameter (Be11, 1975, p. 243). This trough subsidence can be controlled if the brine that is initially removed from a cavity is replaced with saturated brine, preserving the integrity of the cavern roof.

Brine production in Cheshire County today is by a controlled method. Sonar surveys control cavity size and shape, and the borehole leading into 
the cavity is sealed with steel tubing and grouted into place to prevent any leakage. A cushion of air or oil prevents the roof of the cavity from being solutioned. Large pillars are left to support the roof, and the rock surrounding the cavities is dry, preventing any uncontrolled dissolving of the pillars. As a result of these mining techniques, no detrimental subsidence has occurred. (See Bel1, 1975, p. 241.) 


\section{SUBSIDENCE DUE TO SULFUR MINING.}

\subsection{Fannett Salt Dome, Jefferson County, Texas}

Introduction

Sulfur has been mined by the Frasch process from the upper region of the caprock above Fannett salt dome by Texasgulf Sulfur Company since 1958 (Hawkins and Jirik, 1966, p. 30). Ground subsidence data were kept for a 2.5 year period following initiation of production. The following information, unless otherwise noted, is from an investigation by Deere (1961).

\section{Stratigraphy}

Fannett salt dome is located 16 miles southwest of Beaumont, Texas. Salt is reached at a depth of 2080 feet with the caprock at the 741-foot level. The caprock is typical of that found on many Gulf Coast domes, consisting of limestione, gypsum, and anhydrite. Beds of unconsolidated sediments (i.e., sands, gravels, and clays) lie above the caprock. Sulfur is mined from the caprock above the center and outer edges of the dome in the 1300 to 1600 foot level. Halbouty $(1979, p .140)$ records that between 1958 and 1974, approximately 3.2 million long tons of sulfur had been produced.

\section{Subsidence}

While sulfur was being mined, surface subsidence occurred above the mined region. A grid system was laid out over the subsidence area about three months after mining began. Vertical and horizontal motion of the surface was recorded periodically for 2.5 years. Initially, data were collected every two weeks, but later were collected at one to two month intervals. In addition to vertical and horizontal motion of the surface, horizontal motion at depth was recorded by cementing plastic casings into 200- to 500-foot-deep drillholes and then monitoring the change in inclination of these holes by lowering a special instrument into the hole.

Figure 5.1 .1 shows vertical subsidence contours after nine months. Approximately thirty wells operated during this period; the production rate, however, is unknown. Maximum subsidence was 1.5 feet at this time. This displacement does not include an estimated three to six inches addi- 


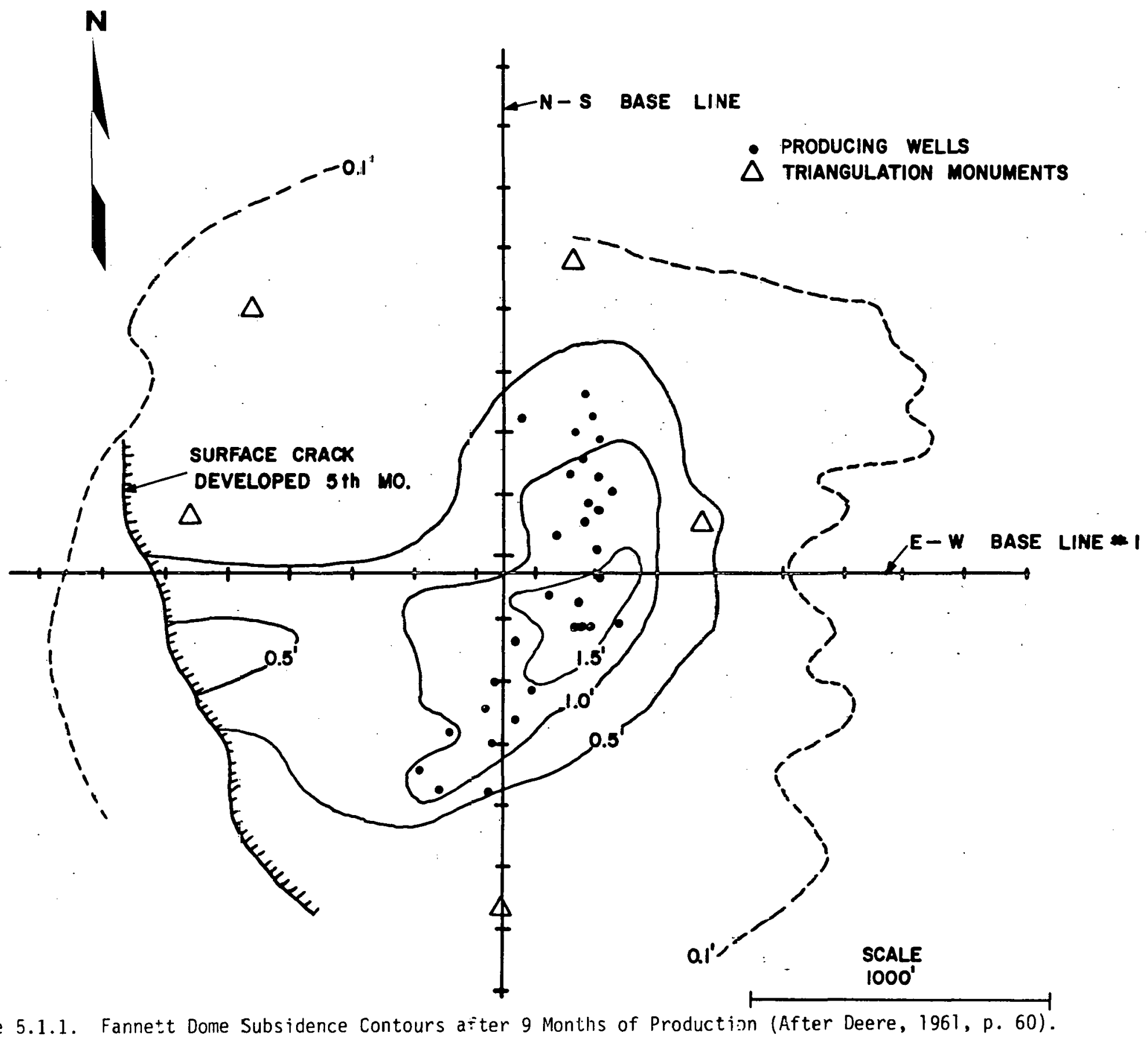


tional subsidence that occurred during the three months prior to establishment of the grid. Initially, a slightly asymmetrical trough formed over the mining and extended outward for about 1000 feet. Development of this subsidence pattern was interrupted during the fifth month of production by the formation of a 2000-foot-liong tension crack west of the trough, as shown in Figure 5.1.1. Differential settlement occurred across this crack, and immediately to the east of the crack one to four inches of additional settl ement was recorded.

Figures 5.1.2, 5.1.3, and 5.1 .4 plot subsidence contours after 15 months, 21 months, and 31 months of production, respectively. These figures also show the location of additional wells that were drilled and operated during these periods. After 15 months, the maximum subsidence increased to three feet, twice that recorded after nine months. After 21 months, the maximum subsidence increased to four feet. Although the fourfoot contour is the maximum shown in Figure 5.1 .4 , Deere reports that some points settled as much as 4.9 feet. Figure 5.1 .4 also shows that the crack extended north and that a small sinkhole formed at the southern end of the crack.

Relative horizontal motion. was measured initially along two perpendicular lines, one east-west line and one north-south line. Later, a second east-west line was established. Figure 5.1 .3 shows the location of these three lines. Horizontal displacement between stations along these lines were used to calculate surface strain. Figures 5.1 .3 and 5.1 .4 show the lengths along the three lines that are in compression. Figure 5.1 .5 plots strain and subsidence along one of the east-west lines. These data do not include subsidence and strain accumulated during the first five months. This plot shows that the strains are compressive over the mined region and become tensile as distance from the mined region increases as expected. The maximum compressive strain is about 0.65 percent and occurs roughly at the point of maximum subsidence. The plot shows increased tension in the vicinity of the crack locited west of the mined area. This is, however, probably not strain in the surface, but simply opening of the erack.

In addition to measuring relative motion on the surface, five monuments were established to measure absolute horizontal motion. The location of these monuments is shown by the symbol $\Delta$ in Figures 5.1 .1 through 5.1.4. 


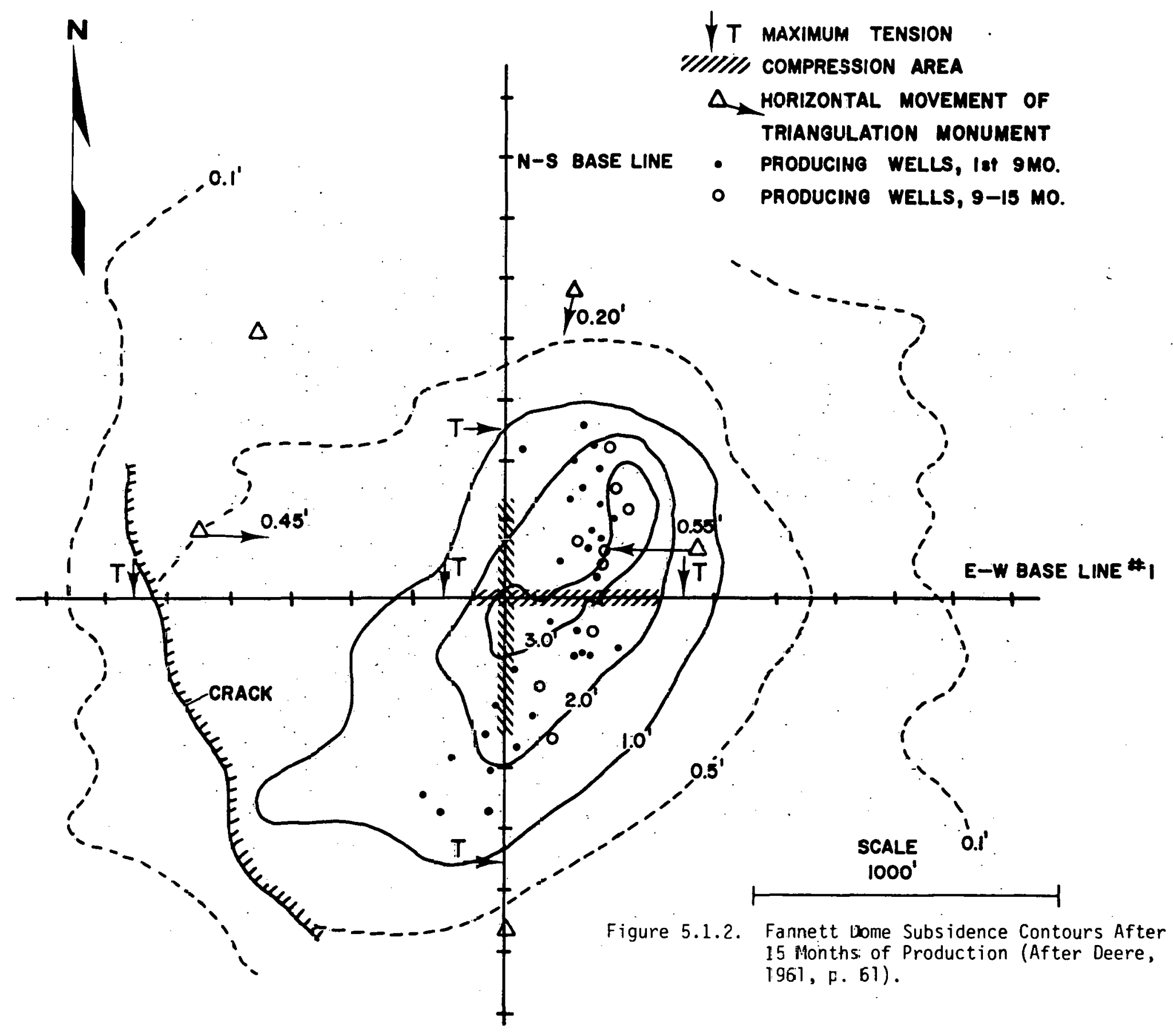




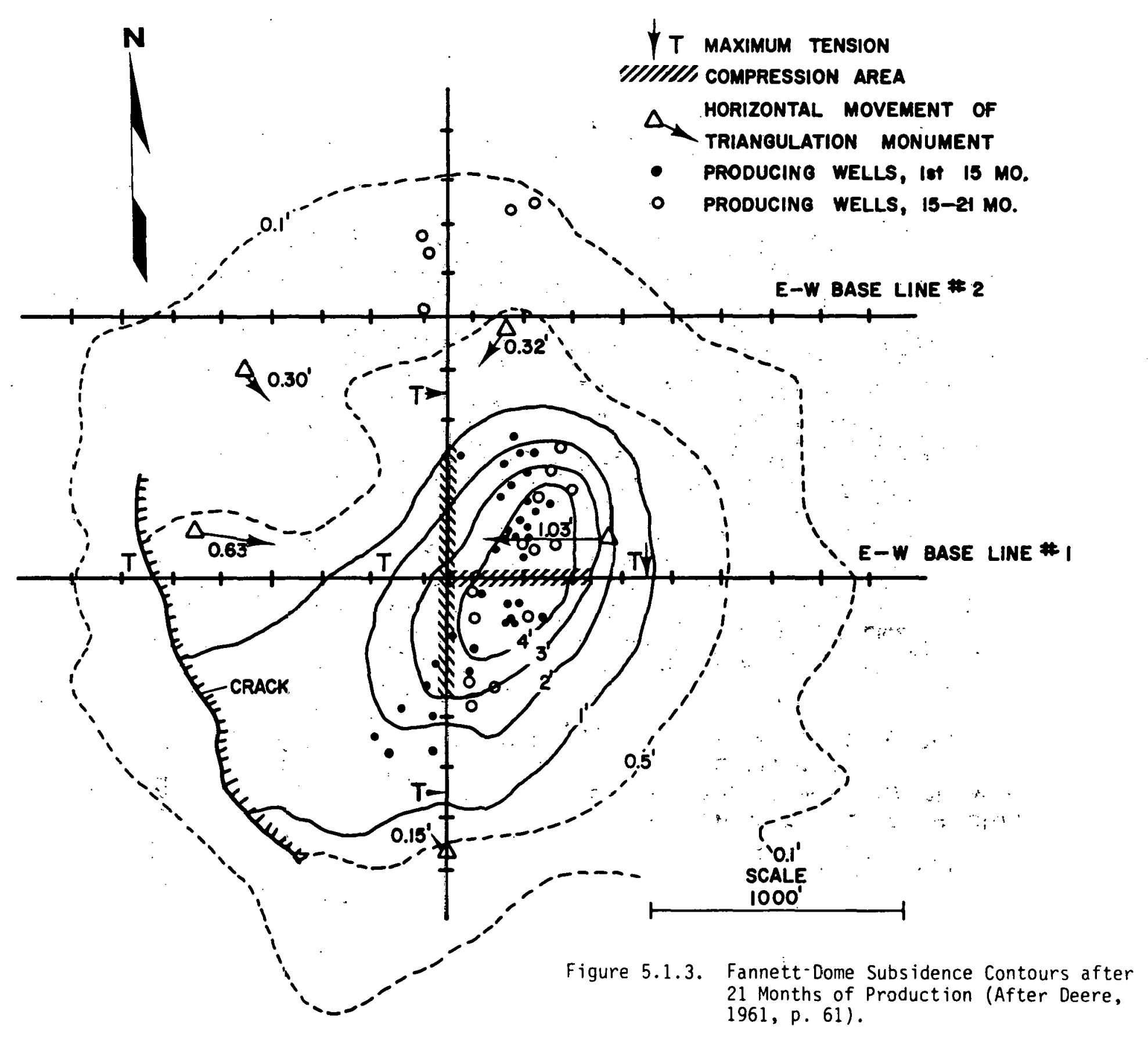




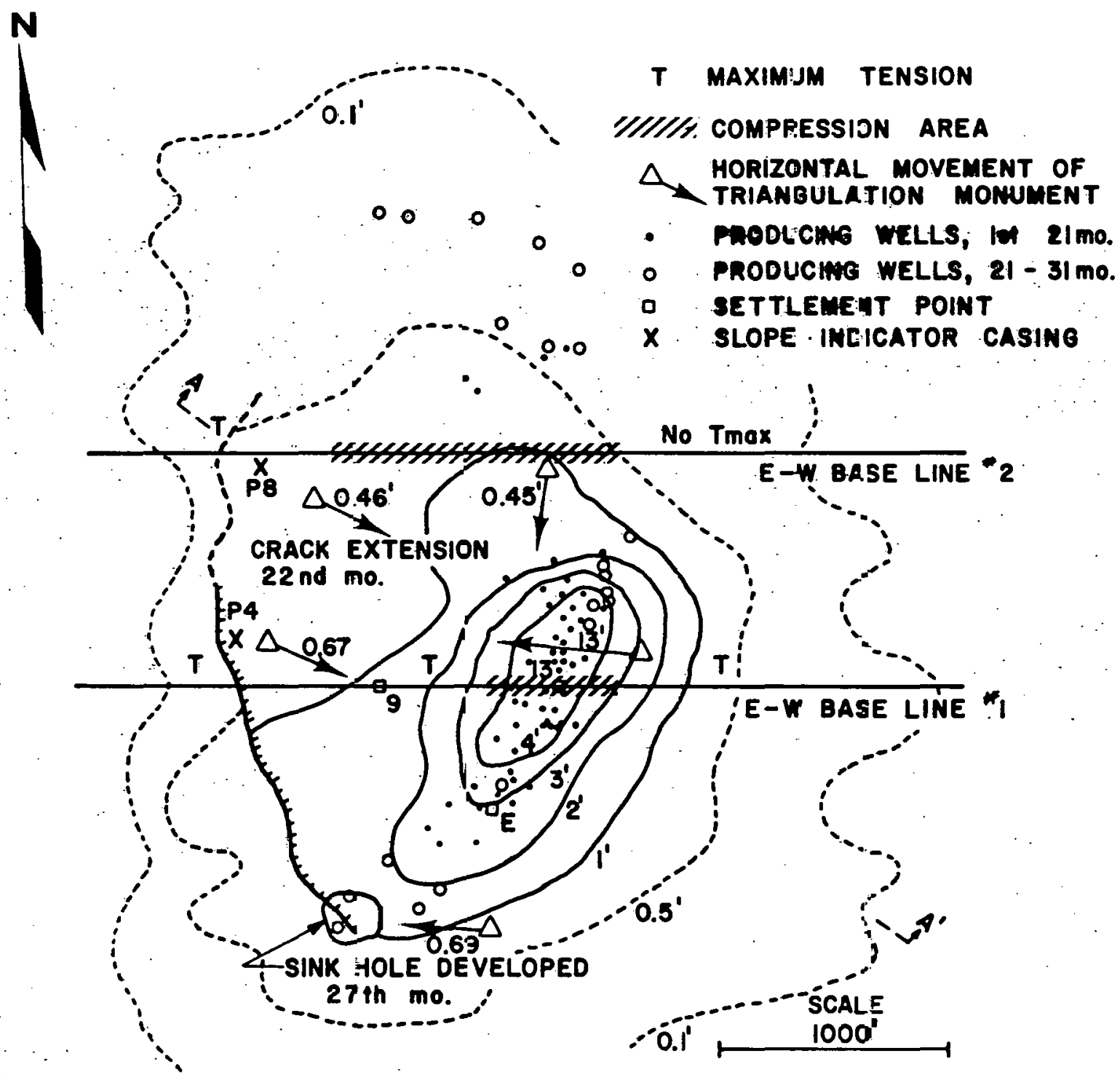

Figure 5.1.4. Farnett Dome Subsidence Contours after 31 Months of Product os: (After Deere, 1961, p. 62). 

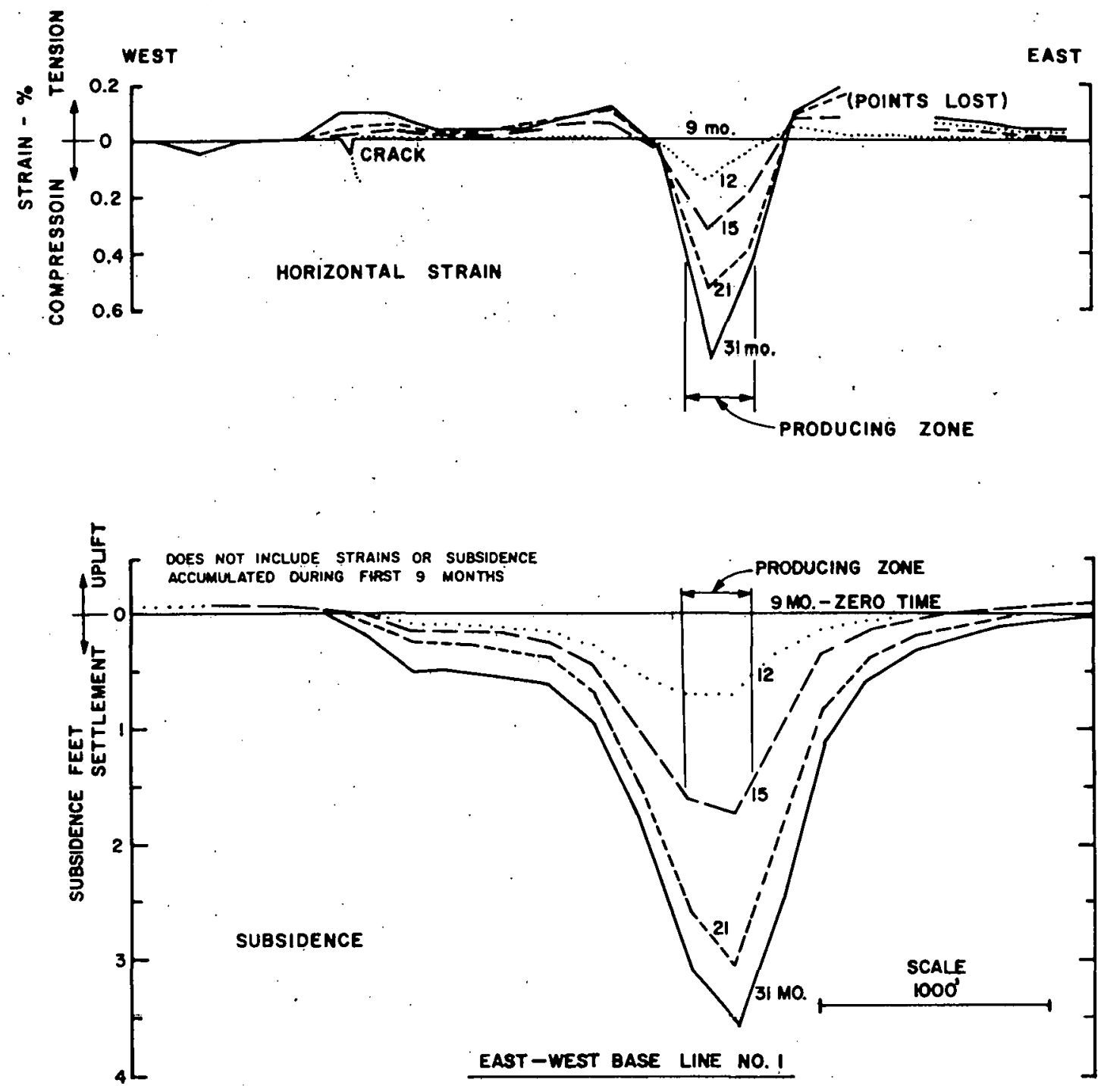

Figure 5.1.5. Subsidence Profile Along East-West Base Line No. 1 (After Deere, 1961, p. 63). 
These monuments moved toward the center of the subsidence by amounts ranging between 0.45 and 1.3 feet.

Measurement of horizontal displacement at depth shows that, within the accuracy of the measurement technique, no motion occurs. An exception is that displacements as large as 4 inches were recorded in the vicinity of the crack, which suggests that the crack extends downward to the east, i.e. toward the mining.

Figure 5.1.6 shows subsidence as a function of time for three points. These three points are labeled 9, 13, and $E$ in Figure 5.1.4. Initially, the subsidence rate is fairly high, about 0.3 feet per month for point 13; located near the center of the subsidence. After about twenty months, however, the subsidence rate dropped by a factor of ten. At point 13, the subsidence rate was approximately 0.04 feet per month. This decrease in subsidence rate corresponds to a decrease in the production rate, so that subsidence and production appear to be closely related. This implies that subsidence will stop soon after production is terminated. 


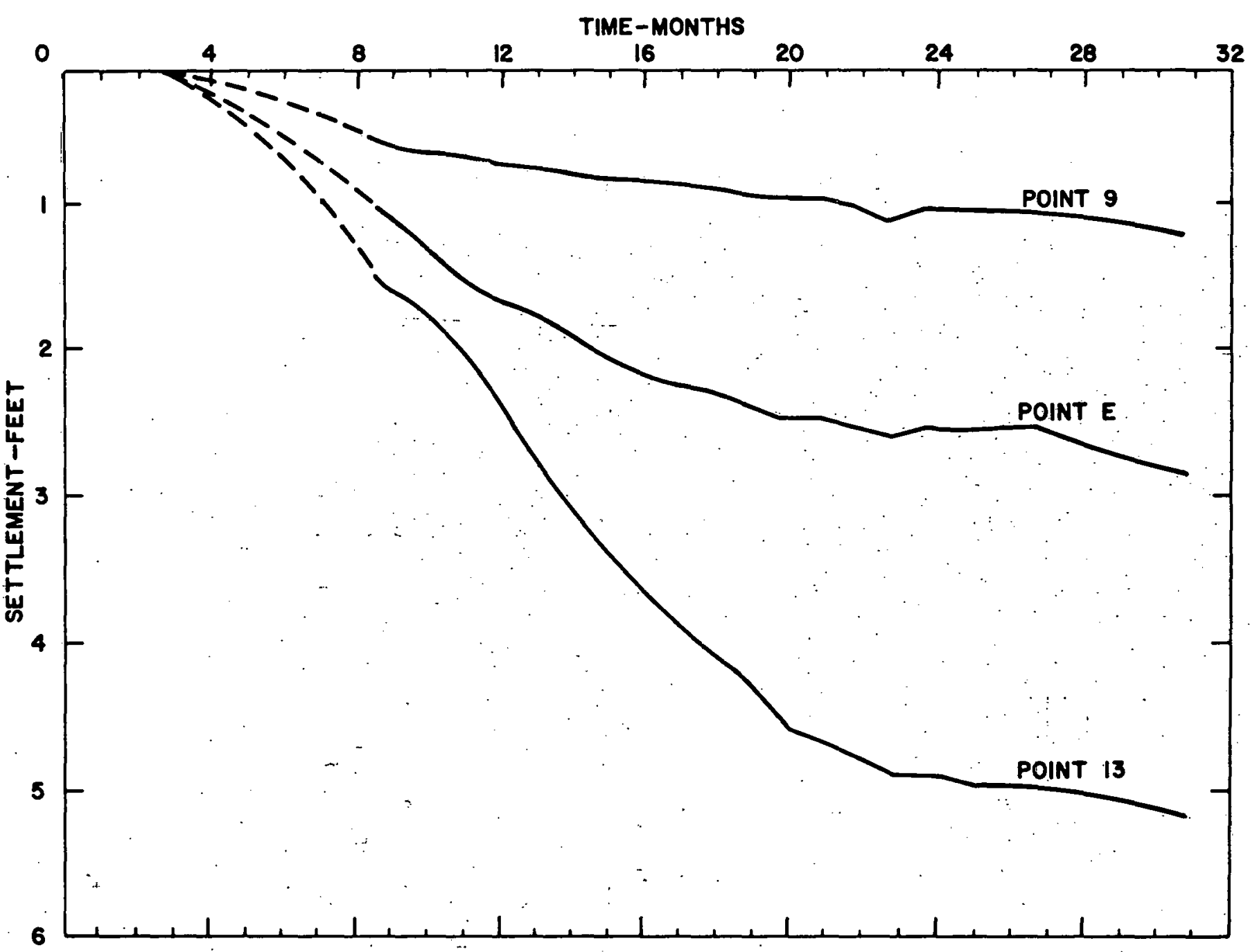

Figure 5.1.6. Fannett Dome Settlement-Versus-Time Curves for Three Points (After Deere, 1961, p. 63). 


\subsection{Sulphur Mines Salt Dome, Calcasieu Parish, Louisiana}

\section{Introduction}

Sulphur Mines salt dome is located in Calcasieu Parish, Louisiana, 15 miles west of Lake Charles, Texas. Frasch sulfur mining occurred between 1894 and 1924 and then again between 1966 and 1970. Subsidence resulting from sulfur mining has occurred in the mining area with as much as 20 feet of vertical displacement at some points.

\section{Stratigraphy}

The salt stock is somewhat flat-topped, having steeply sloping sides. Depth to the top of the salt is approximately 1460 feet. Directly above the salt lies 1100 feet of caprock. This caprock can be divided into 3 layers with the lower portion composed of 400 to 900 feet of pure anhydrite. Above this anhydrite is a transition zone containing limestone, dolomite, anhydrite, gypsum, and vast quantities of, sulfur. Sulfur was mined from this transition at a depth between 800 and 1200 feet. The uppermost layer of caprock, approximately 100 feet, is composed primarily of calcite and extends down the flanks of the dome. (See Bauernschmidt, 1930, p. 1081; PB/KBB, 1978, 3-3 - 3-4.)

\section{Sulfur Mining}

Between 1894-1924, the Union Sulfur Company extracted approximately 9.4 million long tons of sulfur from the Sulphur Mines dome. (Halbouty, 1979, p. 140). $\mathrm{PB} / \mathrm{KBB}(1978$, p. 3-7) indicates that over 10.5 million tons of sulfur was extracted over the same period. If sulfur was extracted evenly over the entire dome, this would be equivalent to a 48-foot-thick layer being removed from the entire dome at the 1100-foot contour level.

As expected, with this much sulfur being removed between 1844 and 1924 , subsidence of the overlying strata has been considerable. Subsidence has been restricted to a 40 -acre area within the 100 -acre production field (SPR, 1977, p. 2-11). Depressions of up to 20 feet have been backfilled in this field and mud has been pumped down into the sulfur-bearing zone to act as a filler for the voids created during the mining process. This was done as an aid to prevent further subsidence. (See PB/KBB, 1978, p. 3-7.) 
Between 1966 and 1970, Pittsburgh Plate and Glass Ind., (PPG) opened a pilot sulfur production operation in the same field that had previously been mined. Halbouty (1979, p. 140) notes that almost 70,000 long tons of sulfur was removed during the pilot operation. Production ceased in 1970 because it was not economically feasible to remove the sulfur.

\section{Subsidence Data}

Between 1967 and 1976, PPG established reference points so that subsidence rates over the field could be recorded. The initial elevations, and those rcad in 1969, were obtained while the pilot plant production was in progress. The last two surveys, those of 1973 and 1976, were taken after production had ceased. Table 5.2.1 shows the change in elevation between each survey and the total elevation change for specified reference points.

\begin{tabular}{|c|c|c|c|c|}
\hline Location & $\begin{array}{l}\text { Change in Elev. } \\
\text { (ft.) between } \\
9 / 14 / 67- \\
11 / 10 / 69\end{array}$ & $\begin{array}{l}\text { Change in Elev. } \\
(\mathrm{ft} .) \text { between } \\
11 / 10 / 69- \\
4 / 3 / 73\end{array}$ & $\begin{array}{l}\text { Change in Elev. } \\
(\mathrm{ft} \text {.) between } \\
4 / 3 / 73 \text { - } \\
9 / 9 / 76\end{array}$ & $\begin{array}{l}\text { Change in Elev. } \\
(\mathrm{ft} \text {.) between } \\
9 / 14 / 67- \\
9 / 4 / 76\end{array}$ \\
\hline $\begin{array}{c}\text { Pump House } \\
\text { No. } 3 \text { Well } \\
\text { No. } 4 \text { Well } \\
\text { No. } 5 \text { Well } \\
\text { No. } 2 \text { Well } \\
\text { No. } 7 \mathrm{~A} \text { Well } \\
\text { No. } 7 \mathrm{~B} \text { Well } \\
\text { No. } 6 \mathrm{X} \text {, No. } 6 \mathrm{Y} \\
\text { Wells } \\
\text { No. } 1 \text { Well } \\
40 ! \text { dia. X } 20^{\prime} \\
\text { Tank } \\
85^{\prime} \times 20^{\prime} \\
\text { Tank Pump Pad } \\
\text { Microwave Tower }\end{array}$ & $\begin{array}{c}-0.234 \\
-0.178 \\
-0.138 \\
--- \\
--- \\
--- \\
-0.093 \\
-0.101 \\
0.175 \\
-.- \\
---\end{array}$ & $\begin{array}{l}-0.412 \\
-0.394 \\
-0.263 \\
-0.212 \\
-0.303 \\
-0.159 \\
-0.157 \\
-0.215 \\
-0.450 \\
0.518 \\
0.491 \\
-0.486\end{array}$ & $\begin{array}{l}-0.329 \\
-0.354 \\
-0.222 \\
-0.225 \\
-0.282 \\
-0.169 \\
-0.170 \\
-0.264 \\
-0.340 \\
0.237 \\
0.293 \\
-0.292\end{array}$ & $\begin{array}{c}-0.975 \\
--- \\
-0.663 \\
-0.575 \\
-- \\
-- \\
-- \\
-0.572 \\
-0.891 \\
0.930 \\
-.- \\
---\end{array}$ \\
\hline
\end{tabular}


These four surveys were taken at approximately the same time intervals; 26, 29, and 31 months. Calculation of the average elevation change per year shows that the subsidence rate was greatest between 1969 and 1973 . This is the period immediately following termination of production. The rate of subsidence between 1967 and 1969 (during production) was less than that between 1973 and 1976 (after production ceased). This indicates that the subsidence rate increased after operations were curtailed and then tapered off somewhat.

Although sulfur has not been mined since February, 1970, subsidence of the field has still been observed (PB/KBB, 1978, p. 3-7). Settlements between 0.7 and 1.3 inches were noted in 1978 . 


\subsection{Hoskins Mound Salt Dome, Brazoria County, Texas}

\section{Introduction}

Hoskins Mound salt dome, located 13 miles east of Angleton, Texas, was mined for sulfur using the Frasch process between 1923 and 1955 by Freeport Sulphur Company. Approximately 10.9 million long tons of sulfur were removed during this time "(Halbouty, 1979; p. 140). Subsidence over the sulfur field after the first five years of production amounted to only four inches (Haynes, 1942, p: 117).

\section{Stratigraphy}

Salt at Hoskins Mound dome is reached at a depth of 1100 feet and the caprock is encountered at 574 feet (Halbouty, 1979, p. 127). The dome is relatively circular and underlies approximately 400 to 500 surface acres. The caprock can be divided into three layers. Immediately overlying the salt and extending down the flanks is a layer of nonporous anhydrite. Above this is the sulfur-bearing limestone which is capped by a layer of porous barren limestone. Figure 5.3.1 details the depth to the salt by the use of a structural contour map. Figure 5.3.2 is a profile of the caprock. As seen in Figure 5:3.2, this sulfur-bearing zone is relatively thin at the center of the dome and becomes increasingly thicker as it extends to the flanks (See Marx, 1936, pp. 155-168).

\section{Subsidence Data}

As was expected, subsidence occurred after mining operations began. In 1924, nitroglycerine was detonated in three wells to induce subsidence because the overlying strata was not settling as fast as operators wanted (Haynes, 1942, p. 117). Freeport Sulphur Company, who produced sulfur from Hoskins Mound, maintains detailed records of subsidence rates and production rates for most of their sites including Hoskins Mound, Grand Ecaille, Lake Pelto, and Straton Ridge. However, company policy does not permit the release of these data. 


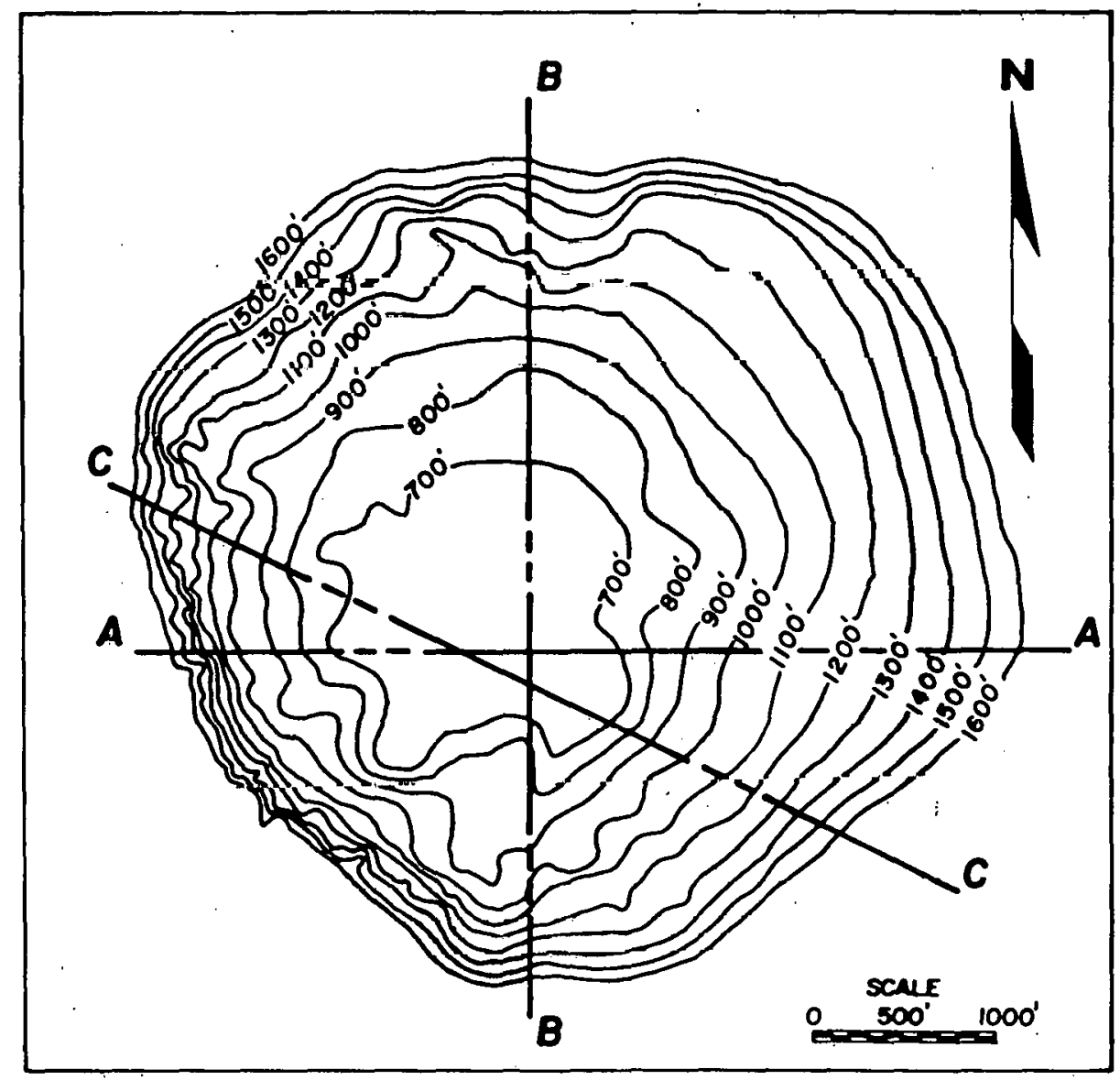

\section{CONTOURS ON TOP OF CAP ROCK HOSKINS MOUND \\ BRAZORIA COUNTY, TEXAS}

Figure 5.3.1. Contour Map Depicting the Depth to =:e Caprock on Hoskins llound (After Marx, 1930, =. 160). 

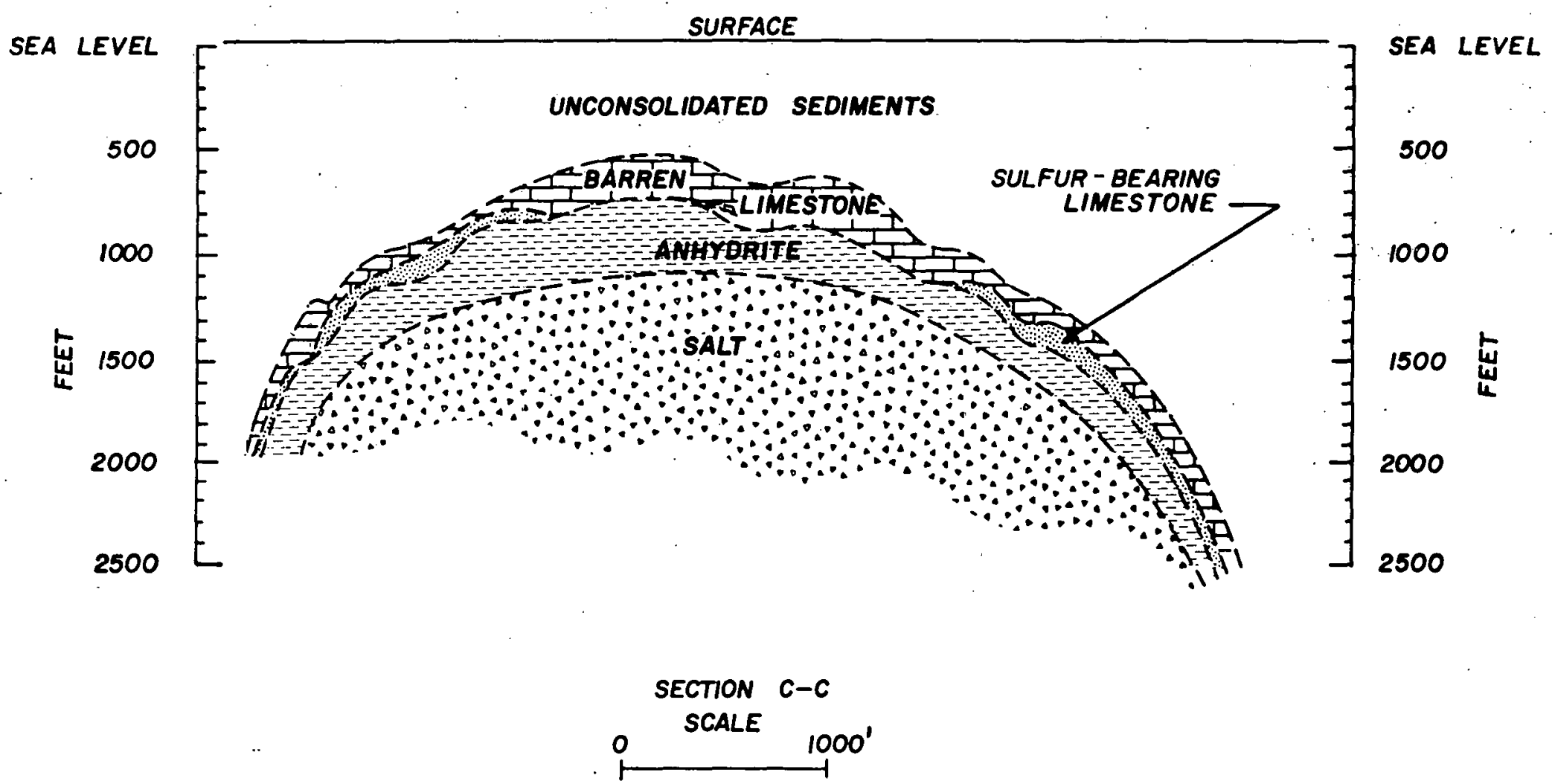

Figure 5.3.2. C-C Cross Section of Hoskins Mound, Texas (After Marx, 1930, p. 164). 


\subsection{Grande Ecaille, Plaquemines Parish, Louisiana}

\section{Introduction}

Grande Ecaille, also known as Lake Washington, was mined for sulfur using the Frasch process between 1933 and 1978. Halbouty (1979, p. 140) records that through 1975, approximately 39 million long tons of sulfur had been removed. This sulfur mining resulted in a significant amount of subsidence of the sulfur field.

\section{Stratigraphy}

The top of the salt ic reached at a depth of 1565 fept with r.aprnok at. the 1094 foot level (Halbouty, 1979, p. 1270). As typical of many Gulf Coast salt domes, the caprock can be divided into three layers. Directly above the salt is an anhydrite layer, followed by the sulfur-bearing 1 imestone, then capped by barren porous limestone. Sulfur was mined from the caprock between the 1200 and 1700 foot level.

\section{Subsidence and Mining}

The sulfur mining operations at Grand Ecaille were restricted to a 1040 -acre field. Smith (1980, p. 24) reports that approximately 1200 producing wells were drilled within this field. The field extended 1.5 miles in the east-west direction and 1.25 miles in the north-south direction, and covered most of the underlying salt dome. Approximately 3900 tons per day of sulfur was produced in 1952. By 1978, when operations were abandoned, 677 tons of sulfur were being recovered each day.

Subsidence over the mining area was nearly 30 feet in some areas. The volume of the overall surface subsidence approached 125 percent of production, so that the entire volume of surface settlement was greater than the volume of sulfur removed. The porous, barren limestone above the sulfur zone may have played a factor in the subsidence-sulfur extraction ratio. As the overlying strata began to collapse with the removal of the sulfur, the voids in the porous limestone were closed, resulting in a mure compact arrangement of sediments. 
Subsidence Data

Annual measurements of subsidence rates and production rates for Grande Ecaille are on file with Freeport Sulfur Company, but once again, access to this data was not permitted. 


\subsection{Spindletop Salt Dome, Jefferson County, Texas}

Introduction

Subsidence resulting from sulfur production has occurred in the sulfur fields that overlie the Spindletop salt dome. In some areas, subsidence has been as great as 25 feet.

\section{Stratigraphy}

Spindletop salt dome is located in Jefferson County, Texas, 3 miles southeast of Beaumont. Spindletop is characterized by a surface mound that rises approximately 16 feet above the surrounding plain. The dome is roughly circular, flat-topped, and has an approximate diameter of one mile. Salt is reached at a depth between 1200 and 1600 feet over the center of the dome (Barton and Paxson, 1926, p. 482-484). The caprock is located at a depth of about 700 feet, and is shaped somewhat like an inverted bowl, leaving the south and southwestern flanks uncovered (Hawkins and Jirik, 1966, p. 31; Barton and Paxson, 1926, p. 485). Gypsum, anhydrite, and limestone are the primary constituents of this caprock. The caprock is extremely porous and oil well logs show some large caverns. Native sulfur was found in crystal form as lining in these caverns. Sulfur was also found as cavity linings in the oil-bearing zone of the caprock (See Barton and Paxson, 1926, p. 486-487).

\section{Mining Operations}

Sulfur has been mined from the caprock using the Frasch method from depths of 900 to 1200 feet (Hawkins and Jirik, 1966, p. 31). Halbouty (1929, p. 140) records that approximately 9.7 million long tons of sulfur were removed between 1952 and 1975. Data indicating the quantity of sulfur removed prior to 1952 and after 1975 are not available.

\section{Subsidence Data}

Subsidence due to the mining of sulfur has been considerable. Some areas record settlements of up to 25 feet. Three ponds resulting from ground settlement and having high $\mathrm{pH}$ values have been created in the sulfur field. 
Data Availability

Texasgulf Company keeps records and maps documenting annual subsidence rates and production rates. However, Texasgulf has a policy similar to that of Freeport Sulfur, and does not permit the release of these data. 


\subsection{Boling Salt Dome, Wharton County, Texas}

\section{Introduction}

Sulfur mining operations began at Boling dome in 1928 and are currently being performed by Texasgulf Sulfur Company. Subsidence of the sulfur field due to the mining operations has been observed.

\section{Stratigraphy}

Boling salt dome, also referred to as Newqulf dome, is located in Wharton County, Texas, 13 miles east-southeast of Wharton. Halbouty (1979, p. 222..223) indicatcs the jizc and shape of Boling dome to be somewhat larger than many other Coastal domes. Boling dome is 5.5 miles long and 3.5 miles wide, elongated on a NW-SE axis. A thrust fault occurs along the southern flank. The shallowest recorded depth to the salt is 975 feet, and the shallowest depth to the caprock is 383 feet (Halbouty, 1979, p. 222).

\section{Mining Operations}

Sulfur mining by the Frasch method first began on the dome in 1928. Four companies have had mining operations at Boling dome, with Texasgulf being the sole operator at present (See Halbouty, 1979, p. 140). Boling dome has been the largest single American producer of sulfur using the Frasch process (Hawkins and Jirik, 1966, p. 30). Table 5.6.1, which contains information on the amount of sulfur produced by each company, is compiled from information found in Halbouty's table (1979, p. 140).

\begin{tabular}{|c|c|c|}
\hline \multicolumn{2}{|c|}{ TABLE 5.6.1. } & SULFUR PRODUCTION AT BOLING DOME \\
\hline COMPANY & OPERATION DATES & $\begin{array}{c}\text { LONG TONS OF SULFUR } \\
\text { REMOVED AS OF 1975 }\end{array}$ \\
\hline Union & $1928-1929$ & 8,009 \\
Texasgulf & $1929-1979$ & $70,660,392$ \\
Duval & $1935-1940$ & 571,123 \\
Baker Williams & 1935 & 1,435 \\
\hline
\end{tabular}




\section{Other Texasgulf Operations}

Texasgulf operated at Big Hill salt dome, also referred to as Gulf or 01d Gulf. Between 1919 and 1936, approximately 12.3 million long tons of sulfur had been removed (Halbouty, 1929, p. 140). Haynes (1942, p. 193) reported that subsidence here was encountered from the onset of the operation, with subsidence sometimes exceeding the amount of sulfur withdrawn as cavities in the caprock collapsed. Texasgulf reopened and operated at Big Hill between 1965 and 1970, removing approximately 502,000 long. tons of sulfur (Halbouty, 1979, p. 140). 


\section{CONCLUSIONS}

An engineering data base was constructed relevant to failure of salt cavities and to surface subsidence caused by sulfur mining. Construction of this data base is the first step to develop capability to perform stability and failure analyses for cavities in salt. One result of this effort is a bibliography comprising more than 150 references germane to cavity failure in salt and surface subsidence due to sulfur mining.

Nineteen failure and subsidence events were documented. Two of these events have sufficient data to be used to verify stability and failure models. The other events lack some critical pieces of data needed for modeling, primarily cavity size and shape and measurements of the failure sequence such as subsidence rates.

The composite data set from these nineteen events is also insufficient to determine quantitatively the influence on cavity stability and failure of parameters such as cavity size and shape, cavity location and stratigraphy. However, some general statements can be made. First, in the cases of excessive cavity closure such as occurred at Eminence and Kiel 101, the cavities are deep, located several thousand feet into the salt. The failures were caused by reduction of the cavity pressure to well below the overburden (in situ) stress. When the cavity pressure is less than the overburden stress, the overburden is supported by a shear (effective) stress in the salt surrounding the cavity. The magnitude of this shear stress is proportional to the difference between the cavity pressure and the overburden stress. The salt creeps in response to this shear stress at a rate determined by the magnitude of the shear stress. Typically, the creep rate in salt depends on shear stress raised to a power that lies between 3 and 5 . Deep cavities, subjected to large overburden stress, then are more likely to suffer excessive closure because the potential for large shear stress is greater than it is for shallow cavities.

In the cases in which the cavity collapsed and produced surface sinkholes, the primary factor contributing to these failures appears to have been the closeness of the cavity roof to the top of the salt. The thickness of the salt above the roof at failure depends on factors such as the length of the roof span and the strength of the strata overlying the salt. As salt is leached from the cavity roof and as the salt creeps under the load of the overburden, load is transferred to the strata above the 
salt, increasing the stress in these less ductile layers. When the strength of these layers is reached, the cavity roof begins to fail. In some cases, failure results when all the salt is leached from the roof and failure is aided by brine intrusion into the overlying argillaceous layers, reducing the strength of these layers. Surface subsidence over these cavities can be the result of the operation of a number of mechanisms such as troughing, stoping, plugging, and piping. The relative contribution of each mechanism to the subsidence influences the sink formation sequence and geometry.

Generally, trough subsidence occurs over areas of sulfur mining and the maximum vertical displacement is approximately equal to the effective thickness of the sulfur layer. Subsidence caused by stoping usually begins soon after mining begins and continues for some time after mining ends. Because stoping enhances production, surface subsidence has been induced with explosives on some occasions when the sulfur-bearing stratum is so competent that it does not fail and result in subsidence.

To predict the onset of failure, failure rate and post-failure geometry requires a model based on a fundamental understanding of the influence on failure mechanisms of parameters such as cavity size, cavity location and stratigraphy. This is probably the largest obstacle in the development of a model to analyze cavity failure because operation of some failure mechanisms depends critically on stratigraphy and the constitutive behavior of the materials it comprises. Therefore, to assess cavity stability and to determine the potential for damage to other structures by cavity failure requires extensive knowledge of stratigraphy, and constitutive behavior in addition to other data such as cavity size, shape and location.

Sillce only sparce data currently exist concerning failure of cavities in salt, model development for stability and failure analyses can by aided by establishing a data base relevant to existing cavities. This data base has three uses. First, it determines normal parameters for intact cavities, such as average depth and average size that can guide design of new cavities. Second, since the failure events documented in this report often lack pre-failure cavity parameters, this data base can provide such information if one of the cavities that has been surveyed fails at some later time. Finally, models developed to analyze cavity stability and failure can be checked against this data base by attempting to predict that existing cavities are stable. 
Allen, A. S., 1969, Geologic settings of subsidence, in Varnes, D. J., and Kiersch, G., eds., Reviews in engineering geology, v. 2: Geol. Soc. America, p. 305-342.

Allen, Kermit, 1971, Eminence - natural gas storage in salt comes of age: Am. Inst. Mining and Metall. Engineers Trans., v. 250, p. 276-279.

Allen, Kermit, 1972, Eminence dome - natural-gas storage in salt comes of age: Journal of Petroleum Technology, p. 1299-1301.

Baar, C. A., 1977, Applied salt-rock mechanics, 1 - The in-situ behavior of salt rocks: New York, Elsevier Scientific Publishing Company, p. 141151.

Barton, D. C., and Paxson, R. B., 1926, The Spindletop salt dome and oi fields, Jefferson County, Texas, in Geology of salt dome oil fields: Am. Assoc. Petroleum Geologists, p. 478-496.

Barton, D. C., 1931, Belle Isle torsion - balance survey, St. Mary Parish, Louisiana, in Am. Assoc. Petroleum Geologists Bull., v. 15, p. 1335-1350.

Bauernschmidt, A. J., Jr., 1930, Sulfur Dome, Calcasieu Parish, Louisiana: Am. Assoc. Petroleum Geologists Bull., v. 14, pt. 2, p. 1079-1086.

Belchic, H. C., April 1-2, 1960, The Winnfield salt dome, Winn Parish, Louisiana: Shreveport Geological Society, Guide Book, 1960 Spring Field Trip, p. 29-44.

Bell, F. G., 1975, Salt and subsidence in Cheshire, England: Engineering Geology, v. 9, no. 3, p. 237-247.

Bell, F. G., ed., 1978, Foundation engineering in difficult ground: Boston, Newnes-Butterworths, p. 356-3.59.

Brandt, C. T., and Nair, K., [1.969], An investigation of the Keil 101 gas storage cavern: Tulsa, Oklahoma, Fenix \& Scisson, Inc., 19 p.

Calvert, A. F., 1915, Salt in Cheshire: Great Britain, Turnbull \& Spears, Edinburgh, $1206 \mathrm{p}$.

Deere, D. V., 1961, Subsidence due to mining - a case history from the Gulf Coast region of Texas, in Fourth Symposium on Rock Mechanics, Proceedings, March 30 - April 1, 1961, p. 59-64.

Fenix \& Scisson, Inc., [1975], Analysis of data from Eminence dome storage caverns: unpublished report prepared for Transcontinental Gas Pipe Line Corporation, $46 \mathrm{p}$.

Fisher, W. L., 1965, Rock and mineral resources of east Texas: Texas Bureau of Economic Geology, Report of Investigation, no. 54, p. 310-311. 
Hager, D. S., and Stiles, E., 1925, The Blue Ridge salt dome, Fort Bend county, Texas: Am. Assoc. Petroleum Geologists Bull., v. 9, no. 2, p. 304-316.

Halbouty, M. T., 1979, Salt domes - gulf region, United States and Mexico (2nd ed.): Houston, Texas, Gulf Publishing Co., 561 p.

Hanna, M. A., 1953, Fracture porosity in Gulf Coast: Am. Assoc. Petroleum Geologists Bull, v. 37, no: 2, p. 266-281.

Hanna, M. A., [1958], Salt domes: unpublished report, 66 p.

Hawkins, M. E., and Jirik, C. J., 1966, Sulfur deposits, in Salt domes in Texas, Louisiana, Mississippi, Al abama, and offshore tidelands - a survey: U. S. Bur. Mines Inf. Circ. 8813, p. 26-41.

Haynes, W., 1942, Brimstone - the stone that burns - the story of the Frasch sulphur industry: D. Van Nost rand Company Inc., 308 p.

Haynes, W., 1942, The stone that burns: D. Van Nostrand Co., Inc., p. 193.

Hendron, A. J., Heuer, R. E., and Fernandez-Delgado, G. , August, 1978, Final report on field investigations at Cargill sinkhole, Hutchinson, Kansas, 8 p.

Hendron, A. J., Jr., Fernandez-Delgado, G., and Lenzini, P. A.., January, 1979, Preliminary report on field investigations of north subsidence area at Cargill, Kansas, for Solution Mining Research Institute, Inc., $32 \mathrm{p}$.

Hendron, A. J., Jr., Fernandez, G., and Lenzini, P., July, 1980, Field investigations of subsidence areas at Carey Salt brinefield, Hutchinson, Kansas, for Solution Mining Research Institute, 44 p.

Hopkins, 0. B., and Powers, S., 1923, The Brooks, Steen and Grand Saline salt domes, Smith and Van Zandt counties, Texas, in Contributions to Economic Geology: U. S. Geol, Survey Bul1. 736, p. 179-239.

Howell, F. T., and Jenkins, P. L., 1976, Some aspects of the subsidence in the rocksalt district of Cheshire, in International Association of Hydrological Sciences Publication, no. 121, Proceedings: Anaheim Symposium, December, 1976, p. 507-520.

Hoy, R. B., Foose, R. M., and 0'Neill, B. J., Jr., August, 1962, Structure of Winnfield salt dome, Winn Parish, Louisiana: An. As soc. Petroleum Geologists Bull., v. 46, p. 1444-1459.

Jaron, M. G., 1970, Investigation of solution collapse breccia in mature salt cavities, in 3rd Symposium on salt, v. 1: Northern Ohio Geol. Soc., p. $422-428$.

Kumar, M. B., and Hoda, B., December 31, 1978, IV-E. Hydrologic studies of Belle Isle salt mine, in An investigation of the utility of Gulf Coast domes for the storage or disposal of radioactive wastes: Louisiana State University, Baton Rouge, LA, Prepared for DOE, ONWI, BMI EW-78-C-05-5941/53, p. 153-187. 
Landes, K. K., and Piper, T. B., April, 1972, Effect upon environment of brine cavity subsidence at Grosse Ile, Michigan-1971: Solution Mining Research Institute, Inc. and BASF Wyandotte Corp., 72-0003-SMRI, 52 p.

Martinez, J. D., Thoms, R. L., Kupfer, D. H., Smith, C. G., Jr., Kolb, C. R., Newchurch, E. J., Wilcox, R. E., Manning, T. A., Jr., Romberg, M., Lewis, A. J., and Rovik, J. E., Sept. 30, 1976, An investigation of the utility of Gulf Coast salt domes for the storage or disposal of radioactive wastes: Institute for Environmental Studies, Louisiana State University, Baton Rouge, Louisiana, Prepared for the Office of Waste Isolation, Union Carbide Corp. - Nuclear Division, U.S. Energy Research and Development Administration, ORNL-SUB-4112-25, p. 317-320.

Marx, A. H., 1936, Hoskins Mound salt dome - Brazoria County, Texas: Am. Assoc. Petroleum Geologists Bull., v. 20, no. 2, p. 115-178.

McIntyre, R. L., May 15, 1980, Report no. 4 - Eminence storage facility, station 77 - operating summary - November, 1979, through April, 1980: unpubl ished report.

Nieto-Pescetto, A. I., and Hendron, A. J., Jr., November, 1977, Study of sinkholes related to salt production in the area of Detroit, Michigan: Solution Mining Research Institute, Inc., 77-0007-SMRI, 50 p.

0 'Connor, R. E., March 17, 1975, Sinkhole on Cargill, Inc. property, Hutchinson, Kansas: The State Department of Health and Environment, Division of Environment, $45 \mathrm{p}$.

$0 i 1$ and Gas Journal, February 15, 1971, Gas stored in salt-dome caverns, v. 69, no. 7, p. 67-70.

Paine, W. R., Mitchell, M. W., Copeland, R. R., Jr., and Gimbrede, L. de A., 1965, Frio and anahuac sediment inclusions, Belle Isle salt dome, St. Mary Parish, Louisiana: Am. Assoc. Petroleum Geologists Bull., v. 49, pt. 1, no. 5, p. 616-620.

PB/KBB, 1978, Properties of caprock in salt dome study, Sulphur Mines, Louisiana: Department of Energy Strategic Petroleum Reserve Program, p. 3-2 - 3-8.

Peck, R. B., July 2, 1954, Memorandum concerning subsidence at Windsor, Ontario: unpublished report, $13 \mathrm{p}$.

Plimpton, H. G., Foster, R. K., Risbeck, J. S., Rutherford, R. P., King, R. F., Buffington, G. L., and Traweek, W. C., 1979, Final report of mine explosion disaster, Belle Isle mine, Cargill, Inc., Franklin, St. Mary Parish, Louisiana, June 8, 1979: U. S. Department of Labor, Mine Safety and Health Administration, $135 \mathrm{p}$.

Powers, S., 1926, Interior salt domes of Texas, in Geology of salt dome oil fields: Am. As soc. Petroleum Geologists, p. 209-344.

Röhr, H. U., 1974, Mechanical behavior of a gas storage cavern in evaporite rocks, in 4th Symposium on salt, v. 2: Northern Ohio Geol. Soc., p. 93-100. 
Short, N. M., 1968, Failure of rock salt by explosive loading at the Winnfield salt mine, Louisiana: Geol. Soc. America Special Paper 88, p. 631-641.

Smith, T. P., March 2, 1980, It just wouldn't say goodbye, in Dixie, The Times-Picayune, New Orleans, Louisiana, p. 22-26.

Strategic Petroleum Reserve, September, 1977, Draft environmental impact statement for Sulphur Mines salt dome, in DES-77-6: Federal Energy Administration, Strategic Petroleum Reserve Office, FEA/S-77/213, p. 2-11-2-12.

Taylor, M., 1930, Shaft sinking at a Texas salt mine: Mining and Metallurgy, v. 2, p. 580-583.

Terzaghi, K., 1954, Report on the subsidence of February 19, 1954, in the brine field of the Canadian Salt Company and Canadian Industries Ltd. in Windsor, Canada: unpublished report, $18 \mathrm{p}$.

Terzaghi, R. D., 1970, Brinefield subsidence at Windsor, Ontario, in 3rd Symposium on salt, v. 2: Northern Ohio Geol. Soc., p. 298-307.

Tillerson, J. R., [in press], Failure of cavern No. 7 at Bayou Choctaw: Albuquerque, New Mexico, Sandia National Laboratory.

U. S. Geol. Survey, [in press], Solution mining and subsidence in evaporite rocks in the United States: Denver, Colorado, U.S. Geol. Survey Misc. Inv.

Vaughan, F. E., 1926, The five islands, Louisiana geology of salt dome oil fields: Am. Assoc. Petroleum Geologists, p. 383-392.

Walters, R. F., 1978a, Land subsidence in central Kansas related to salt dissolution, in Bulletin 24, Kansas Geological Survey, University of Kansas, Lawrence, Kansas, $82 \mathrm{p}$.

Walters, R. F., 1978b, Abstract: Brinefield subsidence, June 1978, Interpace Corporation - Carey Salt Division, Hutchinson, Kansas, [abs.]: Solution Mining Research Institute, Inc., 78-0003-SMRI, 5 p.

Woodall, Howard, pub., Grand Saline Sun, April 29, 1976.

Woodall, Howard, Pub., Salt well cave-in attracts wide interest: Grand Saline Sun, May 6, 1976.

Young, C. M., 1927, Subsidence around a salt well: Am. Inst. Mining and Meta11. Eng. Trans., v. 74, p. 810-817. 


\section{BIBLIOGRAPHY}

Alan, M. H., 1966, Natural gas storage in Saskatchewan, in 2nd Symposium, on salt, v. 2: Northern Ohio Geol. Soc., p. 412-421.

Albrecht, H., and Langer, M., 1974, The rheological behavior of rock salt and related stability problems of storage caverns, in Advances in rock mechanics: Third Congress of the International Society for Rock Mechanics, Denver, Colorado, 1974, v. II, pt. B, p. 967-974.

Allen, A. S., 1969, Geologic settings of subsidence, in Varnes, P. J. and Kiersch, G., eds., Reviews in Engineering Geology, v.2, p. 305-342.

Applin, P. L., 1925, The Stratton Ridge salt dome, Brazoria County, Texas: Am. Assoc. Petrol eum Geologists Bul 1., v. 9, no. 1, p. 1-34.

Arnold, W., Fürster, S., and Menzel, W., 1975, In situ investigations of fracturing in salt cavities for determining stress components, in Processing and Storing, Ninth World Petrol eum Congress, Proceedings: London, Applied Sciences Publishers Ltd., v. 5, p. 89-96.

Aufricht, W. F., and Howard, K. C., 1961, Salt characteristics as they affect storage of hydrocarbons: Journal of Petroleum Technology, v. 13 , no. 8 , p. $733-738$.

Bachman, G. 0., and Johnson, R. B., 1973, Stability of salt in the Permian Salt Basin of Kansas, Oklahoma, Texas, and New Mexico: U.S. Geol. Survey open-file report $73-14,62 \mathrm{p}$.

Balk, R., 1949, Structure of Grand Saline salt dome; Van Zandt County, Texas: Am. Assoc. Petroleum Geologist.s Ru11., v, 33, p. $1791 \cdots 1829$.

Barton, D. C., 1936, Belle Ișle salt dome, St. Mary Parish, Louisiana, in Barton, D. C., and Sawtelle, George, eds., Gulf Coast 0il Fields, A Symposium on the Gulf Coast Cenozoic: Am. Assoc. Petroleum Geologists, p. 1033-1039.

Barton, D. C., 1936, Late Recent history of the Côte Blanche salt dorne, St. Mary Parish, Louisiana: Am. Assoc. Petroleum Geologists Bull., v. 20, no. $2,179-185$.

Be issner, K., Kock, R., Schleicher, H., Dreyer, W., and Fürer, G., 1975, Underground storage of 1 iquid and gaseous hydrocarbons with special consideration to public safety, regional planning and environmental protection, in Processing and Storing, Ninlh Wurld Petroleum Congress, Proceedings: London, Applied Science Publishers Ltd., v. 5, p. 97-107.

Boffey, P. M., 1975, Radioactive waste site search gets into deep water: Science, v. 190 , p. 361 .

Brown, K. E., and Jessen, F. W., 1959, Effects of pressure and temperature on cavities in salts: Journal of Petroleum Technology, v. 11, no. 12, p. $341-345$. 
Burgat, V. A., and Taylor, W. K., 1972, Hi ghway subsidence caused by salt solutioning, in Program \& Abstract: Association of Engineering Geologists Annual Meeting, Kansas City, Missouri, 1972, no. 15, p. 20.

Chang, C.-Y., and Nair, K., 1974, Analytical methods for predicting subsidence above solution-mined cavities, in 4th Symposium on salt, v. 2: Northern Ohio Geol. Soc., p. 101-117.

Chao, R., 1974, Long term creep closure of solution cavity system, in 4th Symposium on salt, v. 2: Northern Ohio Geol. Soc., p. 119-127.

Cook, J. C., 1973, How to locate water hazards in salt mines [abs.], in International symposium on salt, technical program abstract book, no. 4, p. 9.

Cook, T. D., ed., 1972, Underground waste management and environmental implications: Am. Assoc. Petroleum Geologists, Proceedings.

Costinescu, A., and Gloria, K., 1978, In situ investigations to determine the permissible pressure gradient in gas storage caverns in salt [In situ unter suchungen zur ermittlung des]: Erdöel Kohle-ErdgasPetrochem Suppl, v. 1, p. 356-370.

Cummings, A. E., and 0'Donnell, P., 1974, A case history of brine cavity development with intermediate injection, in 4th Symposium on salt, $v$. 2: Northern Ohio Geol. Soc., p. 231-237.

Cunningham, J. P., June 1, 1979, Eminence storage facility operating summary and expected performance: unpublished report for Fenix \& Scisson, $47 \mathrm{p}$.

Dreyer, W. G., 1974, Results of recent studies on the stability of crude oil and gas storage in salt caverns, in 4th Symposium on salt, v. 2: Northern Ohio Geol. Soc., p. 65-92.

Dunrud, C. R., 1978, Solution mine subsidence hazards [abs.]: U. S. Geological Survey Professional Paper no. 1100, p. 290-291.

Eby, J. B., and Halbouty, M. T., 1937, Spindletop oil field, Jefferson County, Texas: Am. Assoc. Petroleum Geologists Bull., v. 21, no. 4, p. 475-490.

Ege, J. R., 1979, Surface subsidence and collapse in relation to extraction of salt and other soluble evaporites: U.S. Geol. Survey open-file report $79-1666,34 \mathrm{p}$.

Fmery, r. 1.., 1970, An experiment to define the strain redistribution at surface caused by a growing cavity at depth [abs.], in 2nd Symposium on salt, v. 2: Northern Ohio Geol. Soc., p. 103.

Engineering and Mining Journal, May, 1973, Large crater forces closure of Belle Isle salt mine, v. 174 , no. 5, p. 32.

Federal Energy Administration, 1976, Final report, project II, engineering feasibility study of underground storage in existing leached caverns in salt formations: Washington, D.C. , Federal Energy Administration. 
Fenix \& Scisson, 1976, Review of applicable technology - solution mining of caverns in salt domes to serve as repositories for radioactive wastes: Tulsa, Oklahoma, Fenix \& Scisson, Inc., 122 p.

Fisher W. L., 1965, Rock and mineral resources of east Texas: Austin, Texas, Bureau of Economic Geology, Report of Investigation no. 54, 71 p.

Goodman, J. V., 1968, Underground gas storage in $0 i 1$ and gas reservoirs in Beebe, B. W., and Curtis, B. F., eds., Natural gases of North America - a symposium: Tulsa, Oklahoma, Am. Assoc. Petrol eum Geologists, v. 2, p. 1865-1888.

Haddenhorst, H. G., Lorenzen, H., and Schwier, K., 1978, Investigations of the storage of LNG in salt caverns [Untersuchungen zur Speicherung von LNG in Salzkavernen]: Erdöel Kohle-Erdgas-Petrochem, v. 31, no. 11, p. 537.

Halbouty, M. T., and Hardin, G. C., Jr., 1959, Exploration techniques on salt domes of the gulf region of the U. S.: $0 i l$ and Gas Journal, v. 57 , no. 24, p. 134-137.

Halbouty, M. T., 1967, Salt domes - gulf region, United States and Mexico: Houston, Texas, Gulf Publishing Co.

Hardy, H. R., Jr., 1977, Dimensional stability of solution mined cavities in salt, in Martinez, J. D., and Thoms, R. L., eds., Salt dome utilization and environmental considerations: Baton Rouge, Louisiana, Louisiana State University, 1976, Proceedings, p. 267-293.

Hendron, A. J., and Nieto-Pescetto, A. S., April, 1973, A study of the development of two sinkholes at Grosse Ile, Michigan, from field records: unpublished report jointly sponsored by Solution Mining Research Institute, Inc. and BASF Wyandotte Corp., $33 \mathrm{p}$.

Hendron, A. J., Fernandez, G., and Lenzini, R., May, 1979, Study of sinkhole formation mechanisms in the area of Hutchinson, Kansas: published by Solution Mining Research Institute, 70-0007-SMRI, 16 p.

Henley, A. S., 1926, The Big Hill salt dome, Jefferson County, Texas, in Moore, R. C., ed., Geology of salt dome oil fields: Am. Assoc. Petroleum Geologists, p. 497-500.

Herrman, F., and Hofrichtes, E., 1973, Subrosion, subsidence and sinkholes related to salt domes in North-Western Germany, exemplified by means of the Benthe salt pluy near Hanover [Subrosion, Bodensenungen und Erdfälle an Salzstöcken NW-Deutschlands am Beispiel des Salzstockes]: Symposium on sirk-holes and subsidence, engineering-yeological problems related to soluble rocks, Hanover, 1y/3, Proceedings, p. $T_{1}-F_{1}-T_{1}-F_{10}$

Hofrichter, E., 1973, The cause of the formation of sinkholes near Vienenburg - leaching of salt in drowned mines [Ursache eines Erdfalles bei Vienenburg - Salzauflösung in ersotfenen Grubenräumen]: Symposium on sinkholes and subsidence, engineering-geological problems related to soluble rocks, Hanover, 1973, Proceedings, P. T1-H.1 T1-H.6. 
Hosman, R. L., 1978, Geohydrology of the northern Louisiana salt-dome basin pertinent to the storage of radioactive wastes - a progress report:

U. S. Geol. Survey, Water-Resource Investigation no. 78-104, 27 p.

Hoy, R. B., and Kühn, Robert, February, 1953, Structure of Winnfield salt dome, Winnfield Parish, Louisiana: in Am. Assoc. Petroleum Geologists, v. 37 , no. 2 , p. $360-361$.

International Association of Science Hydrology, 1971, International symposium on land subsidence, Tokyo, Proceedings: IASH-UNESCO, pub. 88, IASH, v.2, 661 p.

Jacoby, C. H., 1972, Cavity utilization: Am. Inst. Mining and Metall. Eng., Trans. v. 252, p. 143-146.

Jeremic, M. L., 1975, Subsidence problems caused by solution mining of the rock salt deposits, in Canadian Rock Mechanics Symposium, Proceedings, no. 1, p. 203-223.

Jindal, V. K., 1969, Model studies on the effects of solution - cavern closure in salt domes: Louisiana State University, Baton Rouge, Louisiana, M. S. Thesis.

Johnson, P. H., 1931, Sulphur mining in the Gulf Coast, in 0il and sulphur development in the Texas and Louisiana Gulf Coast salt dome region: Texas Gulf Oil Scouts Assoc. and Southern Louisiana Oil Scouts Assoc. Bull. 1, $128 \mathrm{p}$.

Kelly, P. K., 1925, The Sulphur salt dome, Louisiana: Am. Assoc. Petroleum Geologists Bull., v. 9, no. 1, p. 479-496.

Kennedy, W., 1925, The Bryan Heights salt dome, Brazoria County, Texas: Am. Assoc. Petroleum Geologists Bull., v. 9, p. 613-625.

King, H. J., and Jones, M. B., 1956, The measurement of mine subsidence, p. $106-113$.

Kreitler, C. W., 1978, Faulting and land subsidence from groundwater and hydrocarbon production, Houston-Galveston, Texas: Austin. Texas, Bureau of Economic Geology, Research Note 8, 22 p.

Kupfer, D. H., 1963, Structure of salt in Gulf Coast domes, in 1st Symposium on salt, v. 1: Northern Ohio Geol. Soc., p. 104-123.

Kupfer, D. H., 1974, Shear zones in the Gulf Coast salt delineate spines of movement: Gulf Coast Association of Geological Societies, Trans., v. 24, p. 197-209.

Kupfer, D. H., July, 1977, Shear zones inside Gulf Coast salt stocks help to delineate spines of movement: reply: in Am. Assoc. Petroleum Geologists Bull., v. 61, no. 7, p. 1093-1095.

Lambrich, K. H., and Kuehne, G., 1975, Experience gained in the creation and operation of caverns in salt domes with a large content of impurities, in Processing and Storing, Ninth World Petroleum Congress, Proceedings: London, Applied Science Publishers Ltd., v. 5, p. 81-88. 
Lewis, G. L., 1970, The problem of subsidence in salt-producing areas, in 3rd Symposium on salt, v. 2: Northern Ohio Geol. Soc., p. 293-297.

Lorenzen, H., Lux, K. H., and Rokar, R. B., Formulations of rock mechanical calculations applied to cavities in salt domes and stratified salt [Ansaetze zur gibirsbmechanischen berechung von]: Erdoel Kohle-ErdgasPetrochem, 1977 - 1978 compendium, p. 656-668:

Lucus, A. F., 1918, A review of the exploration at. Belle Isle, Louisiana, in Am. Inst. Mining and Metall. Eng. Trans., v. 57, p. 1034-1050.

Marsden, R. W., and Lucas, J. R., coordinating eds., 1973, Specialized underground extraction systems, in Cummins, A. B., and Given, I. A., eds. SME Mining Engineering Handbook: New York, Society of Mining Engineers of AIME, v. 2, sec. 21, p. 1-118.

Martinez, J. D., 1970, Technology of Gulf Coast salt, in Kupfer, D. H., ed. Symposium on the geology and technology of Gulf Coast salt:. Louisiana State University, p. 149-159.

Martinez, J. D., 1971, Environmental significance of sait: Am. Assoc. Petroleum Geologists Bull., v. 55, no. 6, p. 810-825.

Martinez, J. D., June, 1971, Environmental significance of salt: Am. Assoc. Petroleum Geologists, v. 56, no. 6, p. 817-818.

Martinez, J. D., Thoms, R. L., Jindal, V. D., and Kinod, K., 1970, Model studies of effects of closure of solution caverns in salt domes, in 3rd Symposium on salt, v. 2: Northern Ohio Geol. Soc., p. 308-320.

Marx, A. H., 1936, Hoskins Mound salt dome, Brazoria County, Texas, in Barton, D.C., and Sawtelle, G., eds., Gulf Coast oil fields - a symposium on the Gulf Coast Cenozoic: Tulsa. OKlahoma. Am. Assoc. Petroleum Geologists, p. 833-856.

McCreath, D. R., 1978, Underground storage - fuel oil, gas, or compressed air, in Limitations of rock mechanics in energy resource recovery and devel opment: Washington; D.C., National Academy of Sciences, p. 4352.

McIntyre, R. L., September 15, 1979, Eminence storage facility operating summary, November, 1978 - Aprii, 1979: unpublished report for Fenix \& Scisson, 59 p.

McIntyre, R. L., December 1, 1979, Eminence storage facility operating summary, May, 1979 ... Octobcr, 1979: unpublished report for Fenix \& Scisson, $20 \mathrm{p}$.

Medley, A. H., 1975, Storage of natural gas in salt caverns: Society of Petroleum Engineers of the AIME, Northern Plains Section Meeting, preprint no. SPE S427, 9 p.

Medley, A. H., June, 1978, LOOP, federal program to store crude oil in salt domes: Pipe Line Industry, p. 45-46. 
Moore, R. C., 1925, Subsidence in a part of Hutchinson, Kansas; U.S. Geological Survey and State Geological Survey of Kansas, Bull. 176, $100 \mathrm{p}$.

Muehlberger, W. R., 1968, Internal structures and mode of uplift of Texas and Louisiana salt domes, in Mattox, R. B., ed., Saline deposits: Geological Society of America, Special paper no. 88, p. 359-364.

Murray, G. E., 1968, Salt structures of Gulf of Mexico basin - a review, in Braunstein, Jules, and O'Brien, G. D., eds., Diapirism and Diapirs A Symposium: 'Tulsa, Oklahoma, Am. Assoc. Petroleum Geologists, p. 104-105.

Nair, K., and Chang, C.-Y., 1969, Investigation of the influence of certain variables on the subsidence above mined areas: Solution Mining Research Institute, 69-0004-SMRI, 53 p.

Nair, K., and Chang, C. -Y., 1971, Analytical Methods for predicting subsidence: Solution Mining Research Institute, 71-0004-SMRI, $71 \mathrm{p}$.

Nair, K., Chang, C.-Y., and Abdullah, A. M., Analytical Techniques for predicting subsidence-time-dependent analysis: Solution Mining Research Institute, 72-0007-SMRI, $33 \mathrm{p}$.

Nair, K., Chang, C.-Y., Singh, R. D., and Abdullah, A. M., 1974, Time dependent analys is to predict closure in salt cavities, in 4 th Symposium on salt, v. 2: Northern Ohio Geol. Soc., p. 129-139.

Nair, K., and Singh, R. D., 1974, Creep rupture criteria for salt, in 4th Symposium on salt, v. 2: Northern Ohio Geol. Soc., p. 41-49.

Netherland, Sewell \& Associates, 1975, Preliminary study of the present and possible future oil and gas development of areas immediately surrounding the interior salt domes - upper Gulf Coast salt dome basins of East Texas, North Louisiana, and Mississippi as of December, 1975: Dallas, Texas, Netherland, Sewell \& Associates.

Nowot.ny, B.; and Jessen, F. W., 1966, Pressure-temperature effect on spherical cavities in massive salt, in 2 nd Symposium on salt, $v .2$ : Northern Ohio Geol. Soc., p. 363-385.

O'Neill, C. A., 1973, Evaluation of Belle Isle salt dome, Louisiana: Gulf Coast Assoc. of Geol. Soc., Trans., v. 23, p. 115-135.

Obert, L., and Duva11; W. I., 1967, Rock mechanics and the design of structures in rocks: Now York, John Wiley \& Sons, $650 \mathrm{p}$.

Ode, Helmer, 1968, Review of mechanical properties of salt relating to salt-dome gneises, in Braunstein J., and O'Brien, G. D., eds., Diapirism and Diapirs: Am. Assoc. Petroleum Geologists, Memoir 8, p. 53-78.

Panke, L. A., 1970, Methods and equipment for measuring subsidence, in 3rd Symposium on salt, v. 2: Northern Ohio Geol. Soc., p. 321-338. 
Pasiechnyk, L. T., 1978, Solution-mined salt caverns storage of fluid hydrocarbons: Canadian Institute of Mining and Metallurgy, Bull., v. 71, no. 797, p. 91-97.

Patchick, P. F., 1980, The stability of Palestine salt dome, Anderson Co., Texas for disposal of high-level radioactive waste: Columbus, Ohio, Office of Nuclear Waste Isolation, ONWI-74, 35.p.

Pelzel, J., Hemmann, M., and Seifert, G., 1972, Causes and development of subsidence and sinkholes during the flooding of the Friedershall Mine, near Bernburg [Ursachen und Entwicklung der Senkungserscheinungr und Erdfalle bei der Flutung der Grube]: Ber. deutsch. Ges. geol. Wiss. -A. Geol. Paläont, v. 17, no. 2, p. 191-219.

Peters, J. W., and Dugan, A. F., 1945, Gravity and magnetic investigations at the Grand Sal ine salt dome, Van Zandt County, Texas: Geophysics, v. 10 , no. 3, p. 376-393.

Peterson, G. B., Plumeau, D. B., and Parker, J., 1977, Yielding pillars and pressure arches at the Cayuga rock salt mine, in Energy resources and excavation technology: 18th U. S. Smposium on Rock Mechanics, Proceedings, p. 4C6.1-4C6.5.

Pipe Line Industry, March, 1972, Transco pioneers salt cavern storage of high pressure gas, v. 36 , no. 3 , p. 59-60.

Pipe Line Industry, 1975, LOOP to store crude oil in 14 salt dome caverns: v. 43 , no. 5, p. $57-58,60$.

Quiero, C. W., 1977, Current practices in solution mining of salt. in Martinez, J. D., and Ihoms, R. L., eds., Symposium on salt dome utilization and environmental considerations, Baton Rouge, 1976, Proceedings: Institute for Environmental Studies, Louisiana State University, p. 3-41.

Rugers, Z. W., Jr., 1974, Process for refuse disposal in solution-mined salt cavities, in 4th Symposium on salt, v. 2: Northern Ohio Geol. Soc., p. 329-336.

Röhr, H. U., 1969, Factors influencing the leaching of an underground storage reservoir in a salt dome in view of nhtaining information for planning and supervision. I. Planning and supervision of the leaching operation. [über die beim Ausspülen eines Untergrundspeichers in einem Salzstock wirksamen Einflussgrössen in Henblick auf die Gewinnung von Planungs - und Überwachungsunterlagen. I. Planung und Uberwachung des Ausspulens]: Erdöl und Kohle-Erdgas-Petrochemie, v. 22, no. 11, p. 670-679.

Röhr, H. U., 1969, Factors influencing the leaching of an underground storage reservoir in a salt dome in view of obtaining information for planning and supervision. II. Evaluation of the convergence of an underground cavity in the salt [über die beim Ausspülen eines Untergrundspeichers in einem Salzstock wirksamen Einflussgrössen Hinblick auf die Gewinnung von Planungs-und überwachunsunteslagen. II. Ermittlung der Konvergerz eines unterirdischen Hohl raumes in Salz]: Erdöl und Kohle-Erdgas-Petrochemie, v. 22, no. 12, p. 734-741. 
Roux, C. B., and Pottier, M. M.', 1973, Studies about creation and exploitation of gas storage cavities in salt layers: Twelfth International Gas Union, World Gas Conference paper no. I, GU/A 27-73, 18 p.

Saberian, A., and Podia, A. L., 1977, A computer model for describing the development of solution-mined cavities: In situ (USA), v. 1, no. 1, p. 1-36.

Sawtelle, G., 1936, Salt dome statistics: Am. Assoc. Petroleum Geologists Bull., v. 20, no. 6, p. 726-735.

Sellards E. H., 1907, Origin of sinkholes: Science, v. 26, p. 417.

Serata, S. S., and Gloyna, E. F., 1960, Principles of structural stability of underground salt cavities: Journal of Geophysical Research, v. 65, no. 9, p. 2979-298\%.

Serata, Shosei, 1973, Rock mechanics problems of solution cavities used for storage of gaseous and solid matters, in Society of Mining Engineering of AIME, preprint no. 73-AM-79, $26 \mathrm{p}$.

Serata, Shosei, 1973, Stress control methods applied to salt mines and solution cavities [abs.], in International symposium on salt, technical program abstract book, no. 4, p. 25-26.

Serata, Shosei, 1974, Use of salt cavities for storage of gas and fluid fuels in the energy crisis: Society of Mining Engineers of the AIME, Annual Meeting, preprint no. 74-H-64, $14 \mathrm{p}$.

Serata, Shosei, 1974, Utilization of stress envelopes in design of solution cavities, in 4th Symposium on salt, v. 2: Northern Ohio Geol. Soc. p. 51-64.

Serata, S. S., [1974], Development of research program for detection, prediction, and prevention of surface failure over solution cavities by using REM computer techniques: Solution Mining Research Institute Annual Report (November 1973 - October 1974), 74-0005-SMRI, 47 p.

Serata, Shosei, 1978, Geomechanical basis for design of underground salt cavities: ASME Petroleum Division Energy Technology Conference, Houston, 1978, preprint no. 78-PET-59, 43 p.

Slater, G. E., 1975, Salt caverns - multi-purpose storage vessels: Earth and Mineral Sciences, v. 44, no. 5, pt. 33, 37-38.

Smith, C. G., Martinez, J. D., and Thoms R. L., 1976, Hydrologic stability of north Louisiana salt domes - potential sites for radioactive waste disposal [abs.]: Am. Assoc. Petroleum Geologists Bull., v. 60, no. 4, p. 724 .

Sriow, R. H., and Nielsen, H. J., 1970, II TRI-SMRI solution mining studies, in 3rd Symposium on salt, v. 1: Northern Ohio Geol. Soc., p. 341-357.

Snyder, J. D., and Dellwig, L. F., 1961, Plastic flowage of salt mines at Hutchinson and Lyons, Kansas: State Geol. Survey of Kansas, Bull. 152 , p. $31-46$. 
Sowers, G. F., 1976, Mechanisms of subsidence due to underground openings in, Subsidence over mines and caverns, moisture and frost actions, and classifications: Transportation Research Board National Academy of Sciences, Transportation Research Record 612, p. 2-8.

Spooner, W. C., 1926, The Winnfield salt dome: Am. Assoc. Petroleum Geologists Bull., v. 10, no. 3, p. 328-334.

Strategic Petroleum Reserve, 1977, 0il spill risk from cavern storage, in Capline group salt domes, DES77-9: Federal Energy Administration, Strategic Petroleum Reserve Office, FEA/S-77/341, P. E-3.

Stump, Daniel, 1980, A hypothesis for sink devèlopment above sulutionamine brine cavities in the Detroit area: University of Illinois at Urbana-inampatyn, M. 3. thessi 3, 106 p.

Thomas, T. M., 1973, Solution subsidence mechanisms and end-products in southeast Breconshire: Institute of British Geographers, Trans., no. 60 , p. 69-86.

Thompson, E., and Ripperger, G. A., 1964, An experimental technique for the investigation of the flow of halite and sylvite, in 6th Symposium on Rock Mechanics: Rolla, Missouri, 1964, Proceedings, p. 467-488.

Thoms, R. L., and Martinez, J. D., Blowouts in domal salt: Institute for Environmental Studies, Louisiana State University, Baton Rouge, Louisiana, p. 405-411.

Tulsa Daily World, (April 28), 1976, Sinkhole swallows yard.

von Schonfeldt, H. A., 1974, Model studies in solution mining, in 4th Symposium on sa!t., v. 2: Northern Ohio Geol. Soc., p. 181-188.

Ward, T., 1886, On the subsidence in the salt district of Cheshire - their history and causes: Manchester Geological Society Trans., v. 19, p. 152-178.

Wilson, H. H., July, 1977, Shear zones inside Gulf Coast salt stocks help to delineate spines of movement: discussion: in Am. Assoc. Petroleum Geologists Bull., v. 61, no. 7, p. 1090-1093.

Woidt, W. D., 1978, Fintte element calculations applied to salt dome analysis: Tectonophysics, v. 50, p. 369-386.

Wolf, A. G., 1926, Big Hill salt dome, Matagorda County, Texas, in Moore, R. C., ed., Geology of salt dome oil fields: Am. Assoc. Petroleum Geologists, p. 691-717.

Wony, K. W., 1975, A manual on ground surveys for the detection and measurement of subsidence related to solution mining: Solution Mining Research Institute, 75-0003-SMRI, $127 \mathrm{p}$. 
Distribution:

U.S. Department of Energy

Strategic Petroleum Reserve Program office

1000 Independence Avenue SW

Washington, DC 20585

Attn: L. Pettis

R. Smith

U.S. Department of Energy

Strategic Petroleum Reserve Project Mgmt. Office

900 Commerce Road East

New Orleans, LA 70123

Attn: C. C. Johnson

G. A. Stafford

C. L. Steinkamp

E. E. Chapple (5)

Aerospace Corporation

880 Commerce Road West

suite 300

New Orleans, LA 70123

Attn: K. Henrie

Aerospace Corporation

P. O. Box 92957

Los Angeles, CA 90009

Attn: G. F. Kuncir

Dravo Utility Constructors, Inc.

850 Clearview Parkway

New Orleans, LA 70123

Attr: R. Heaney (2)

Jacobs/D'Appolonia Engineers

6226 Jefferson Highway

Suite $B$

New Orleans, LA 70123

Attn: H. Kubicek

F. Campiell

$\mathrm{RE} / \mathrm{SPEC}$, InC.

P. O. Box 725

Rapid City, SD 57709

Attn: P. Senseny (10)

BASF Wyandotte corporation

Wyandotte, MI 48192

Attn: T. Piper

Solution Mining Research Institute (2)

812 Muriel Street

Woodstock, IL 60098 
$\mathrm{PB} / \mathrm{KBB}$, Inc.

11999 Katy Freeway \#600

Houston, TX 77079

4000 A. Narath

4500 E. H. Beckner

4510 W. D. Weart

4540 M. L. Kramm

4543 J. F. Ney (2)

4543 M. H. Gubbels

4543 G. H. Whiting

4751 J. R. Tillerson

8214 P. A. Childers

3141 L. J. Erickson

3151 W. I. Garner (3)

For: DOE/'ILC (Unlluited Release)

DOE/TIC (25) C. Dalin, 3154-3 